\title{
Description of some Salticidae (Araneae) from the Malay Archipelago. I. Salticidae of the Lesser Sunda Islands, with comments on related species
}

\section{Описание некоторых Salticidae (Araneae) из Макайского Архипелага. I. Salticidae Малых Зондских островов с комментариями о бцизких видах}

\author{
Jerzy Prószyński*, Christa L. Deeleman-Reinhold** \\ Й. Прушиньский*, К. Аияеман-РейнольА**
}

\footnotetext{
* Museum and Institute of Zoology, Polish Academy of Sciences, ul. Wilcza 64, 00-679 Warszawa, Poland. E-mail: jerzy.Prószyński@wp.pl

**4619GA Ossendrecht, the Netherlands. E-mail: cdeeleman@planet.nl
}

KEY WORDS: Salticidae, new species, diagnostic characters, geographical distribution, Indonesia, Bali, Flores, Lombok, Sumba, Sumbawa.

КЛЮЧЕВЫЕ СЛОВА: новый вид, диагностические признаки, распространение, Индонезия, о. Бали, о. Флорес, о. Ломбок, о. Сумба, о. Сумбава.

\section{In memoriam}

Bohdan Pisarski, friend of J. Prószyński and companion in the Java and Bali collecting trip in 1959, for many years the Director of the Institute of Zoology PAN.

ABSTRACT. This paper provides preliminary reference diagnostic drawings for selected Oriental genera and species, to complement the existing scanty literature. The following new taxa are described: new genus - Katya gen.n., new species: Burmattus pachytibialis sp.n., Carrhotus sundaicus sp.n., Chrysilla deelemani sp.n., Cosmophasis valerieae sp.n., Cytaea whytei sp.n., Euryattus [?] junxiae sp.n., Katya florescens sp.n., Katya ijensis sp.n., Katya inornata sp.n., Ligurra moniensis sp.n., Meata zabkai sp.n., Myrmarachne balinese sp.n., Myrmarachne glavisi sp.n., Myrmarachne jacksoni sp.n., Phaeacius azarkinae sp.n., Siler lewaense sp.n., Stergusa incerta sp.n., Thyene gangoides sp.n. and Thyene benjamini sp.n.

The following new combinations and synonyms are established: Artabrus jolensis Simon, $1902=$ Telamonia jolensis (Simon, 1902) comb.n., Euophrys chiariatapuensis Tikader, 1977 = Thiania bhamoensis Thorell, 1887 syn.n., Evarcha kochi Simon, 1902 (reinstated as separate species), Gangus concinnus (Keyserling, 1881) = Thyene concinna $($ Keyserling, 1881) comb.n., Gangus decorus Simon, 1902 = Thyene decora (Simon, 1902) comb.n., Gangus longulus Simon, $1902 \mathrm{a}=$ Thyene longula (Simon, 1902) comb.n., Gangus manipissus Barrion \& Litsinger, 1995 = Thyene manipisa (Barrion \& Litsinger, 1995). Original combination Emertonius exasperans Peckham \& Peckham, 1892 is reinstated. The subdivision of the genus
Myrmarachne MacLeay, 1839 is discussed. Complementary diagnostic drawings are added for the following species: Artabrus erythrocephalus (C.L. Koch, 1846), Harmochirus brachiatus (Thorell, 1877), Hasarius adansoni (Audouin, 1826), Myrmarachne hirsutipalpi [?] Edmunds \& Prószyński, 2003, Spartaeus spinimanus (Thorell, 1878), Thiania bhamoensis Thorell, 1887. Several unidentified species are also mentioned, whenever they contribute to our knowledge of the geographical distribution of their respective genera.

РЕЗЮМЕ. В статье приведены иллюстрации для некоторых ориентальных родов и видов в дополнение к неполным литературным источникам. Описаны следующие новые таксоны: новый род Katya gen.n., новые виды: Burmattus pachytibialis sp.n., Carrhotus sundaicus sp.n., Chrysilla deelemani sp.n., Cosmophasis valerieae sp.n., Cytaea whytei sp.n., Euryattus [?] junxiae sp.n., Katya florescens sp.n., Katya ijensis sp.n., Katya inornata sp.n., Ligurra moniensis sp.n., Meata zabkai sp.n., Myrmarachne balinese sp.n., Myrmarachne glavisi sp.n., Myrmarachne jacksoni sp.n., Phaeacius azarkinae sp.n., Siler lewaense sp.n., Stergusa incerta sp.n., Thyene gangoides sp.n. и Thyene benjamini sp.n. Предложен ряд новых комбинаций и новая синонимия для: Artabrus jolensis Simon, 1902 = Telamonia 


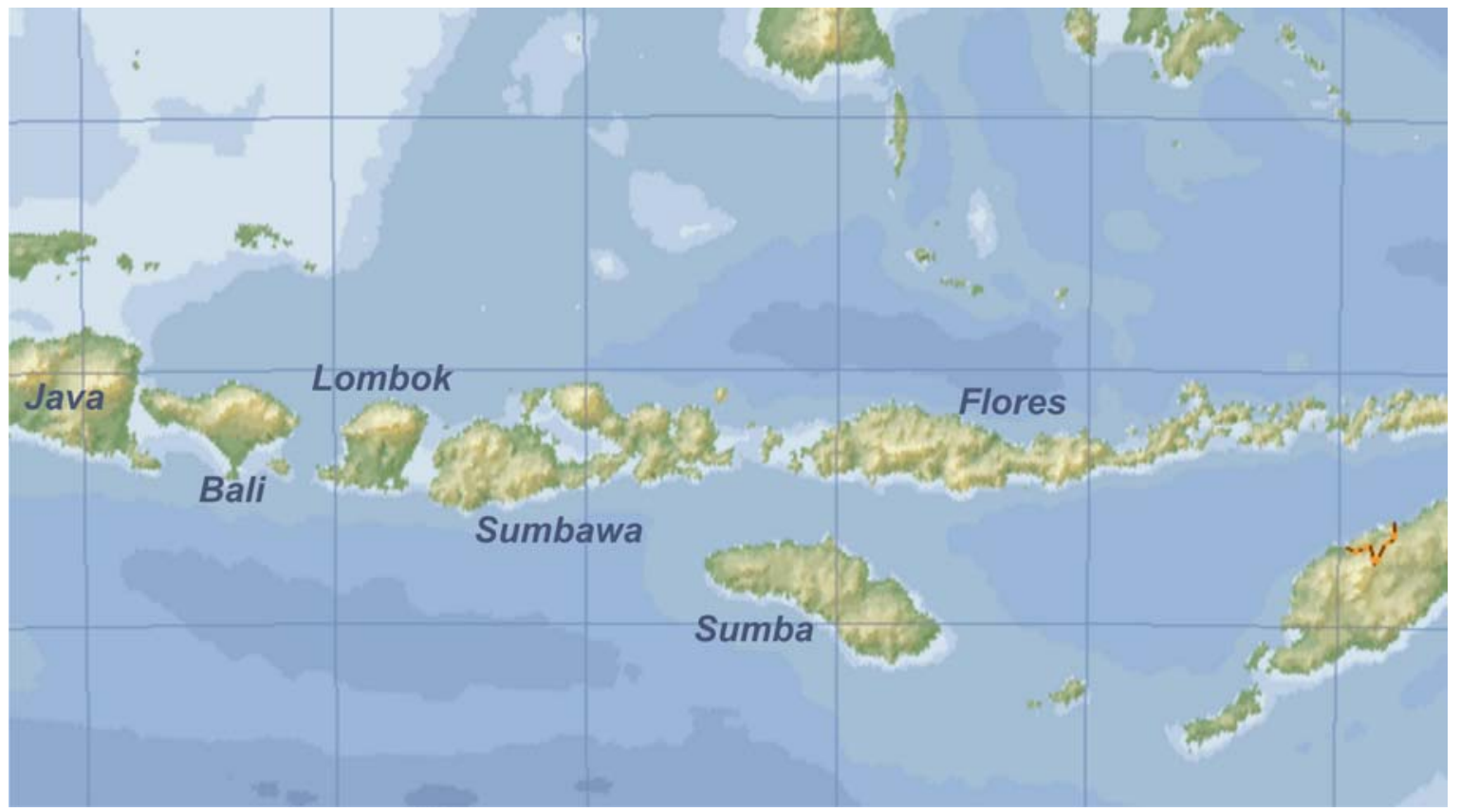

Map 1. Lesser Sunda Islands.

Карта 1. Малые Зондские острова.

jolensis (Simon, 1902) comb.n., Euophrys chiariatapuensis Tikader, $1977=$ Thiania bhamoensis Thorell, 1887 syn.n., Evarcha kochi Simon, 1902 [восстановлен в статусе вида], Gangus concinnus (Keyserling, $1881)=$ Thyene concinna $($ Keyserling, 1881) comb.n., Gangus decorus Simon, 1902 = Thyene decora $($ Simon, 1902) comb.n., Gangus longulus Simon, 1902a = Thyene longula (Simon, 1902) comb.n., Gangus manipissus Barrion \& Litsinger, $1995=$ Thyene manipisa (Barrion \& Litsinger, 1995). Восстановлена оригинальная комбинация Emertonius exasperans Peckham \& Peckham, 1892. Обсуждается подразделения рода Myrmarachne MacLeay, 1839. Приводятся новые рисунки для Artabrus erythrocephalus (C.L. Koch, 1846), Harmochirus brachiatus (Thorell, 1877), Hasarius adansoni (Audouin, 1826), Myrmarachne hirsutipalpi [?] Edmunds \& Prószyński, 2003, Spartaeus spinimanus (Thorell, 1878) и Thiania bhamoensis Thorell, 1887. Упоминается ряд неопределенных видов, в том случае если сведения о них расширяют данные о распространении тех или иных родов.

\section{Introduction}

The Malay Archipelago is politically divided into several countries, and harbors one of the richest faunae of the world. It is a classic area of zoogeographic and evolutionary research, initiated by the memorable book of Wallace [1881]. Strangely, relatively few publications have dealt Salticidae from the Archipelago, and our knowledge of that fauna is particularly incomplete. For example, Indonesia has 330 described species of Salticidae, but only 215 of these having any diagnostic drawings available (only 83 have drawings for both sexes, so the remaining species without such documentation are hardly recognizable). Similarly, the Philippines have 95 species, but only 85 have diagnostic drawings. In contrast Central America has 485 species (414 with diagnostic drawings) and North America has 502 species (447 with diagnostic drawings) [Prószyński, 2010 online]. It can be expected that the fauna of tropical Indonesia will be more diverse than that of mainly temperate North America.

An additional complication with regard to our knowledge of Salticidae from the Malay Archipelago is that some species are described from a single, or a few locations, but their distributions are generalized to include entire large islands or the whole archipelago.

The broader distributions of even better defined species have not been documented by diagnostic drawings, and often represent summaries of misidentified related species.

The current insufficiency of data for Salticidae preclude the investigation of several interesting biological questions.

For example, what is the geographical speciation pattern of Salticidae in the Malay Archipelago? One can expect that each small island may harbor its own species, and larger islands should have chains of related species - but do they? What is the transition pattern of Salticidae between the Asiatic mainland and Australia? To what extent is the distribution of Salticidae influenced by the classic Wallace's Line?

This paper cannot answer these or similar questions, but it defines a number of new or poorly known species, in some cases extending significantly the known geographic ranges. The faunal relationships between larger islands and groups of smaller islands cannot be 
resolved yet, although some hints are discernible even from the preliminary data.

Identifications and definitions of species in Salticidae are based on comparison with existing diagnostic drawings of Salticidae in the literature, as summarized in the Internet database "Monograph of Salticidae (Araneae) of the World" by Prószyński [2010 online, a summary of all previous versions since 1995]. The basis of identification is highly insufficient for Salticidae of the Oriental Region: many species previously described in the world's literature are in fact single examples of larger clades, the existing diagnostic documentation is incomplete, and there are a number of genera for which only one sex was described.

The main aim of this paper is to provide preliminary reference diagnostic drawings to complement the scanty literature data for certain genera and species. The genera and species are classified provisionally, pending revisions of related genera, especially their insufficiently studied type specimens. An untapped source of taxonomic information are photographs of Salticidae, available now on the internet, some of which are used in this paper to draw attention to particularly interesting species. The authors realize the limited sample sizes of the described material, but assume that it will promote future taxonomic research.

\section{Materials and Methods}

The research was done on specimens singled out from the collection of C.L. Deeleman-Reinhold (CDML), donated to the Nationaal Natuurhistorische Museum («Naturalis») (formerly Rijksmuseum van Natuurlijke Historie) in Leiden, the Netherlands, but physically still stored in her home in Ossendrecht. The holotypes are marked in the collection by red chips, paratypes by blue chips.

One species was collected from Bali by B. Pisarski \& J. Prószyński and is kept in the Museum and Institute of Zoology, Polish Academy of Sciences in Warsaw. Specimens from several other collections were studied for comparison.

BMNH - Natural History Museum (British Museum), London, UK.

CDML - Collection of C. L. Deeleman-Reinhold.

MCSN - Museo Civico di Storia Naturale, Genova, Italy.

MiIZ - Museum and Institute of Zoology, Polish Academy of Sciences in Warsaw.

MNHN - Muséum National d'Histoire Naturelle, Laboratoire de Zoologie (Arthropodes), Paris.

NHMW - Naturhistoriches Museum, Wien.

NHRM - Natural Hisrory Museum, Stockholm.

ZMB - Museum für Naturkunde, Leibniz Institute for Research on Evolution and Biodiversity at the Humboldt University, Berlin, Germany

The original examination of the specimens was carried out in the 1990ies, as the beginning of planned, more extensive studies, which unfortunately did not mate- rialize. The relationships of the described species are illustrated by drawings of relevant species taken from the literature [Prószyński, 1984b, 1987, and others]. All original drawings for this paper are made by J. Prószyński.

Specimens were studied under a stereomicroscope, with magnification up to $100 x$. Palpal organs were detached, fixed in sand in an ethanol filled Petri dish. After examination they were put in microvials together with the original specimens. The epigynes were drawn in situ. For study of the internal structures the epigynes were dissected, soaked in 10-20\% solution of $\mathrm{KOH}$ (under controlled conditions for 25 hours), stained in alcohol solution of Chlorazol Black E and mounted in Clove oil for examination under a compound microscope. Subsequently, the epigynes were deposited in a microvial with ethanol and stored together with the original specimen. All drawings were made using a grid system. Species are defined in this paper by pictures of their genital organs and body features, studied in single specimens and compared with drawings of type species and all other species of each genus, shown in Prószyński [2010 online]. There was no possibility to study morphological variation within species. Furthermore, specimens had changed in appearance as a result of their long preservation, so careful comparisons with fresh specimens will be required in the future.

Some specimens were measured by standard methods as described elsewhere [Berry, Beatty \& Prószyński, 1996]; abbreviations used are as follows.

LC - length of carapace in $\mathrm{mm}$.

LE - length of eye field (shown as ratio to length of carapace).

$\mathrm{HC}$ - height of carapace (shown as ratio to length of carapace).

WE1 - width of eye field at eyes I (shown as ratio to length of carapace).

WE3 - width of eye field at eyes III (shown as ratio to length of carapace).

WC3 -width of carapace at eyes III (shown as ratio to length of carapace).

$\mathrm{MW}$ - width of carapace, maximal (shown as ratio to length of carapace).

LDC - length of flat dorsal surface of carapace (shown as ratio to length of carapace).

LA - length of abdomen (shown as ratio to length of carapace).

MWA - width of abdomen at mid-length (shown as ratio to length of carapace).

Length of leg I (5 distal segments), shown both in $\mathrm{mm}$ and as ratio to length of LC.

Length of legs I-IV (5 distal segments), shown both in $\mathrm{mm}$ and as ratio to length of leg $\mathrm{I}$.

\section{Taxonomic survey}

Agorius sp.

REMARK. Species of Agorius Thorell, 1877 were not previously reported from the Lesser Sunda Islands. 
The collection of C.L. Deeleman-Reinhold contains many unidentified males and females from Bali.

\section{Genus Artabrus Simon, 1902}

REMARK. The taxonomic position of the genus is unclear. At present it is considered monotypic, with the single species Artabrus erythrocephalus (C.L. Koch, 1846), presumably to be subdivided into several closely related species (see below) in the future. The only known specimen of Artabrus planipudens (Karsch, 1881) from the Gilbert Islands is apparently a female of Plexippus paykulli Audouin, 1826 [Prószyński, 2009: 162, f. 6]. Artabrus jolensis Simon, 1902 [Prószyński, 1987: 3, 2010 online] is not congeneric with the type species because of the entirely different type of palpus (Figs 171-172), resembling rather Telamonia festiva Thorell, 1887 (see below, also Prószyński, 1984a: 421423, f. 11-17, 2010 online], the type species of the genus Telamonia Thorell, 1887.

Artabrus erythrocephalus (C.L. Koch, 1846) Figs 1-12.

Plexippus erythrocephalus C.L. Koch, 1846: 102, f. $1164\left(\sigma^{7}\right)$ Artabrus erythrocephalus: Simon, 1903: 736, f. 846-847 ( $\left.0^{7}\right)$. Artabrus erythrocephalus: Prószyński, 1984b: 1 ( ( $)$. Artabrus erythrocephalus: Prószyński, 1987: 2-3 (O'o). Artabrus erythrocephalus: Zhang et al., 2003: 188, f. 1A-E $\left(\sigma^{\top}+\right)$.

Artabrus erythrocephalus: Prószyński, 2010 online $\left(O^{\top}\right.$ (O).

MATERIAL. $4 \sigma^{\top} \sigma^{\top}, 2$ 우, "Sumbawa: Samokat, $20 \mathrm{~km}$ of Sumbawa Besar, 480 m. secondary forest, 3.01.1990. Leg. S. Djojosudharmo. CDML.

COMPARATIVE MATERIAL. $\sigma^{\top}$ lectotype, $\rightarrow$ paralectotype "Plexippus erythrocephalus Koch, Type, Java, ZMB 1726". ZMB 1 б", 1 ㅇ "20524. Ar. [tabrus] erythrocephalus C.L. K. Java: Tenngeth" MNHN. 1 ऽ "Artabrus erythrocephalus (CLK) Lombok" - NHMW.

DIAGNOSIS. Recognizable by the palpus (Figs 34), epigyne, and its internal structures (Figs 8-11).

DESCRIPTION. Male. Height of carapace about equal to length of the eye field, the latter rectangular, occupying approximately half the length of the carapace (Figs 1-2). Posterior slope of thorax steep, originating two thirds along the length of the carapace. Eyes of the second row very small, located on low swellings, together with nearby anterior lateral eyes. Abdomen oval, narrow, about 1/5 longer than carapace, about as high as carapace, gradually tapering posteriorly. Pedipalpal tibia long, slightly longer than cymbium, broader distally with very short apophysis (Figs 4-5). Bulbus oval, embolus arising at the posterior, prolateral end of bulbus, proximally fleshy, then narrowing abruptly after the bend, running alongside bulbus, distinctly longer than it. Chelicerae set vertically, robust, with retrolateral tooth in a form of long, sclerotized ridge (Fig. 12).

Female. Resembling male. Epigyne sclerotized, narrow plate, with diagonal copulatory openings, with sclerotized rims in anterior half of epigyne, coils of spermathecae translucent posteriorly, narrow median pocket broader in Sumbawa specimen than in Java specimen (Figs 8-9). Copulatory ducts sclerotized, almost as broad as openings, running posteriorly parallel to the body axis, at the median pocket turning 180 degrees, then near mid-length of ducts making another 180 degrees turn backwards, finally joining spermathecal chamber lying dorsally to the coils of ducts (Fig. 10). These coils are shown as globular chambers in drawings of the specimen from Java (Fig. 11) [Prószyński, 1987] and Singapore [Zhang et al., 2003: f. 1C], but it is not clear now whether this represents a genuine difference or a diagrammatic simplification.

REMARKS. Due to diversity in genital structures the conspecific status of the Sumbawa specimen require confirmation by further research. A. erythrocephalus remains temporarily the single species in this genus.

DISTRIBUTION. Documented from Singapore and Indonesia: Greater Sunda Islands and Lombok, new to Sumbawa.

\section{Burmattus pachytibialis sp.n.} Figs 13-16, 19, 20.

MATERIAL. "O holotype, $\sigma^{7}$ allotype, Sumbawa: Samokat, S of Sumbawa Besar, secondary forest, 400-480 m, at night, 3.01.1990. Leg. S. Djojosudharmo". CDML.

COMPARATIVE MATERIAL. "Plexippus pococki Th. Burma: Tharrawady [Oates ded.] No. 1792" - Coll. Thorell, NHRM.

ETYMOLOGY. Meaning "having a thick tibia".

DIAGNOSIS. Differs distinctly from the type species of the genus Burmattus Prószyński, 1992, viz. Plexippus pococki Thorell, 1895 from Burma (Figs 17-18): in the male by a broader tibial apophysis and less tapering embolus, in the female by the shape of the epigyne, spermatheca and ducts [see Żabka 1985: 434439, f. 473-480].

DESCRIPTION. Male. Carapace high, with most of surface flattish, slightly rounded in profile, with posterior slope abrupt (Figs 13-14). Color pattern comparable to the photograph of B. pococki from Okinawa, Japan by A. Tanikawa [displayed in Prószyński 2010 online], but with some distinct differences. There are two triangular light spots on posterior slope of thorax, separated by darker triangle, and white marginal band along ventral rim of carapace (Fig. 13), there is no large white spot in anterior half of eye field. Abdomen oval, broader anteriorly, with darker design on light background. Length of carapace 2.30, proportions (shown as ratio to length of carapace) LE 0.48 , HC 0.74, WE1 0.71, WE3 0.74, WC3 0.87, MWC 0.87, LDC 0.44, LA 1.04, MWA 0.61, Leg I 2.29. Length of legs (5 distal segments) in $\mathrm{mm}$ and as ratio to leg I: leg I $5.27=1.00$, leg II $4.46=0.85$, leg III $4.98=0.94$, leg IV $5.40=1.02$. Length of legs order: IV, I, III, II.

Female. Epigyne median split distinctly broader, and sclerotized wings more spaced and shorter than in B. pococki (Thorell, 1895) [see Żabka 1985: 434, f. 478-480]; posterior edge of median pocket distinctly bent in (Figs 19-20). Copulatory openings posterior, with duct thick-walled, running anteriorly parallel to pocket, scent opening prominent, at the bend of duct. First part of spermatheca posterior, bag shaped, passes 

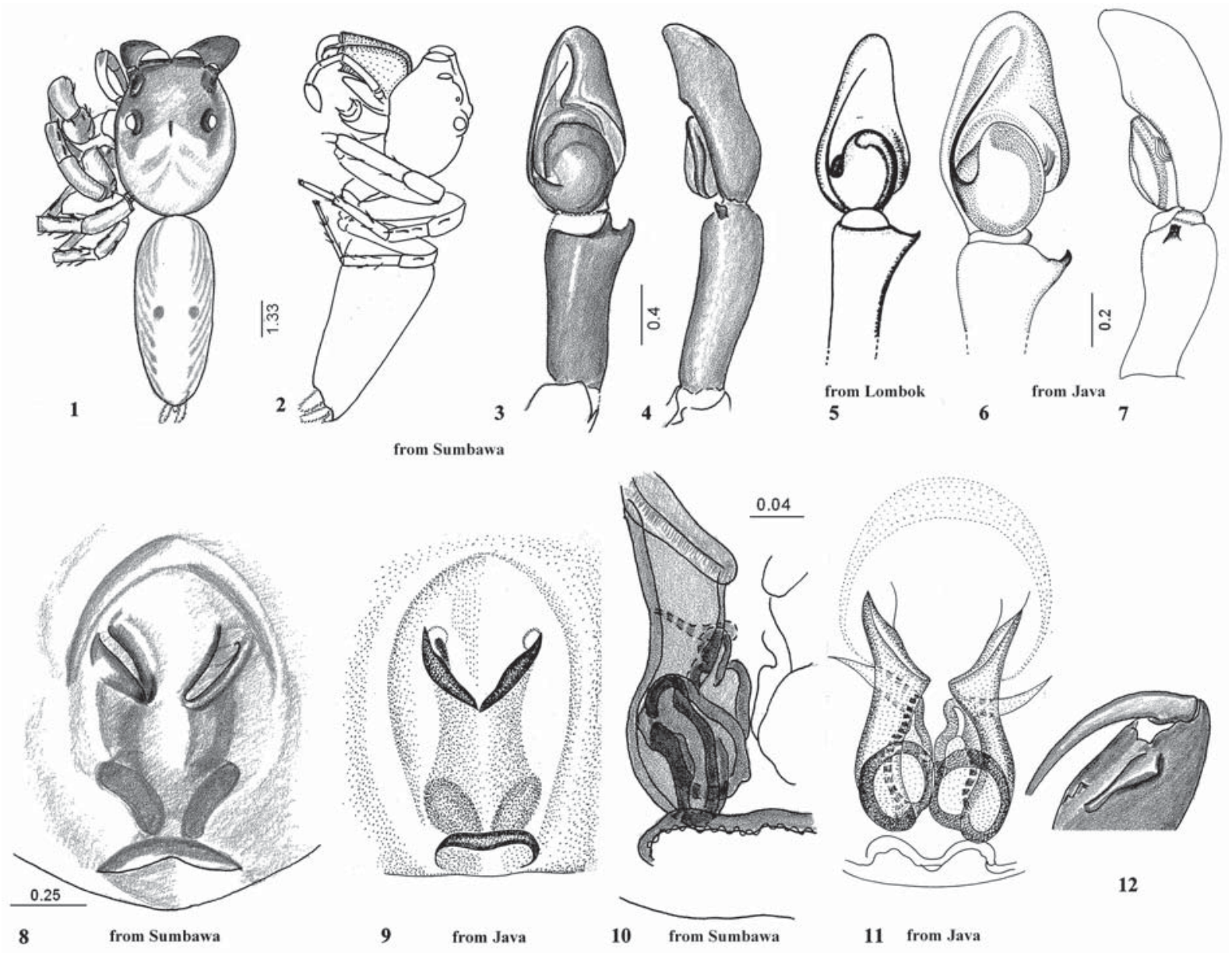

Figs 1-12. General appearance and copulatory organs of Artabrus erythrocephalus: 1-2 - general appearance, dorsal and lateral views; 3-7 - palpus, ventral and lateral views; 8-11 - epigyne and its internal structures; 12 - chelicera, posterior view. 1-4, 8, 10, 12 from Sumbawa, 5 - from Lombok, 6-7, 9, 11 - from Java). 5 - after Prószyński [1984b]; 6-7, 9, 11 — after Prószyński [1987].

Рис 1-12. Общий вид и копулятивные органы Artabrus erythrocephalus: 1-2 - общий вид, сверху и сбоку; 3-7 - пальпа, снизу и сбоку; 8-11 - эпигина и внутренние структуры; 12 - хелицера, сзади. 1-4, 8, 10, 12 - с о. Сумбава, 5 - с о. Ломбок, 67, 9, 11 — с о. Ява. 5 - по Prószyński [1984b]; 6-7, 9, 11 — по Prószyński [1987].

into anterior part located more dorsally (Fig. 20). Length of carapace 2.70, proportions (shown as ratios to length of carapace) LE 0.48 , HC 0.55 , WE1 0.70, WE3 0.70, WC3 0.81, MWC 0.81, LDC 0.67, LA 0.156, MWA 0.96 , leg I 193 (as of LC). Length of legs (5 distal segments) in $\mathrm{mm}$ and as ratio to leg I: leg I 5.20=100, leg II $5.10=0.98$, leg III $5.80=1.11$, leg IV $6.10=1.17$. Length of legs order: IV, III, I, II.

REMARK. The position of the embolus in this genus resembles somewhat Arasia mullion Żabka, 2002 [Żabka, 2002: 258-259, f. 1C], but body shape and cheliceral dentition are different.

DISTRIBUTION. Documented from Indonesia: Sumbawa Island.

\section{Carrhotus sundaicus sp.n.}

Figs 21-24, 27, 28.

MATERIAL. $\sigma^{7}$ holotype (with palpus separated), $1 \sigma^{7}$ paratype, 1 allotype " Carrhotus sp. Lombok: Kute, secondary forest, from leaves, 8-19.01.1990. Leg. S. Djodjosudarmo”. CDML.
COMPARATIVE MATERIAL. o' "Carrhotus viduus C.L. K. Burma: Tharrawady (Oates). No 1770d" - coll. Thorell, NHRM. + holotype "7737 M.[ogrus] ornatus E. S. Malacca "[= Carrhotus viduus ?]. MNHN.

ETYMOLOGY. Living in Sunda Islands.

DIAGNOSIS. Resembles closely Carrhotus viduus (C.L. Koch, 1846), from which it differs by having a narrower bulbus and a more wavy embolic tip (Figs 23-25). Spermathecae with a bigger, more spherical proximal chamber.

DESCRIPTION. Male. Robust and hairy (Figs 2122), with color pattern resembling other Carrhotus species, carapace medium high and long, distinctly longer and lower than in C. malayanus Prószyński, 1992 [Prószyński, 1992: 167, f. 1-5], chelicerae robust, stretching diagonally forward, with mesal constriction. Cheliceral tooth prominent, very broad, with flattish and blunt distal edge (Fig. 26). Palpus (Figs 23-24) resembling Carrhotus viduus specimen from Myanmar (Fig. 25) by wavy embolus, located anteriorly to bulbus, and also by shape of tibial apophysis, 


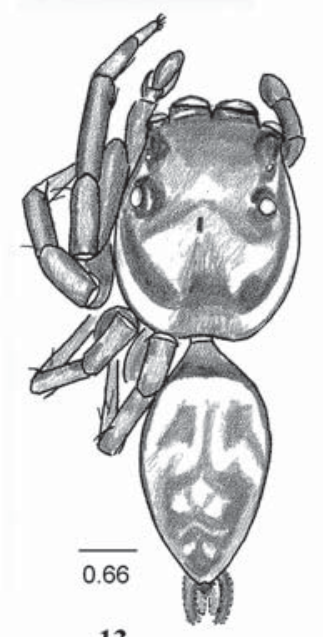

13

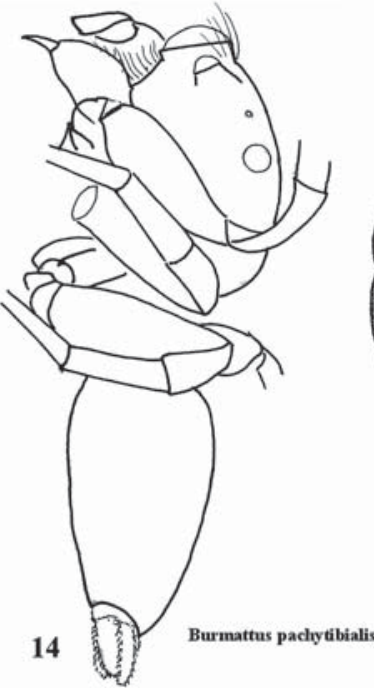

15

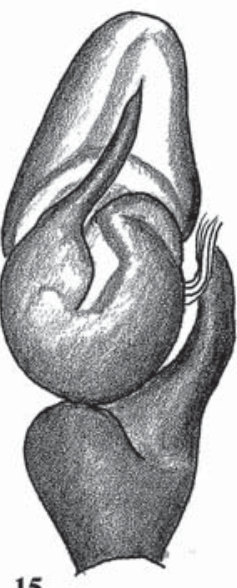

16
ঙฺุ

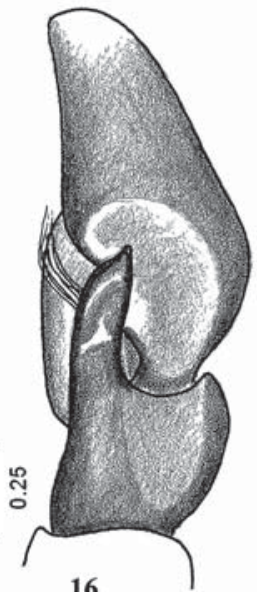

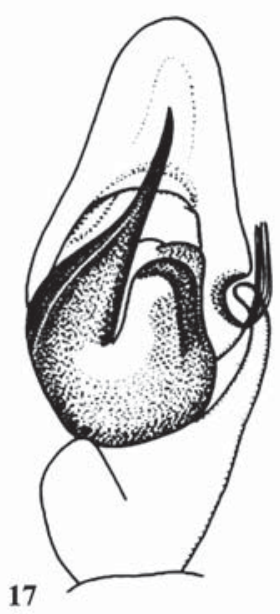

17

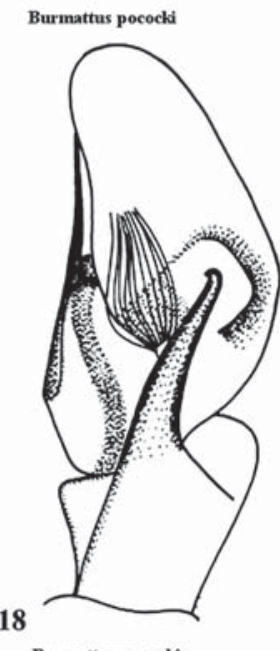

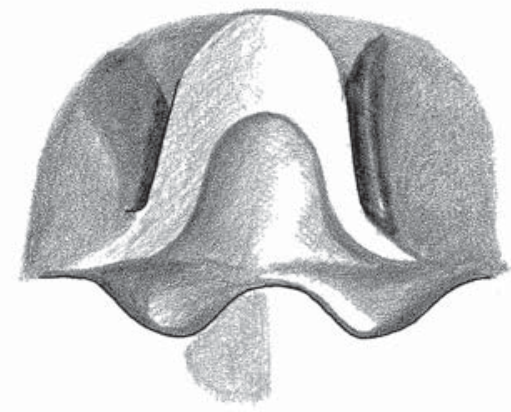

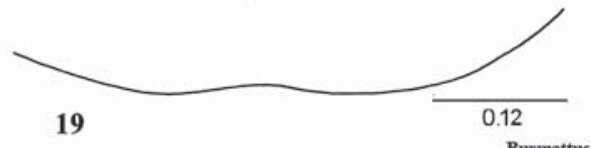

20

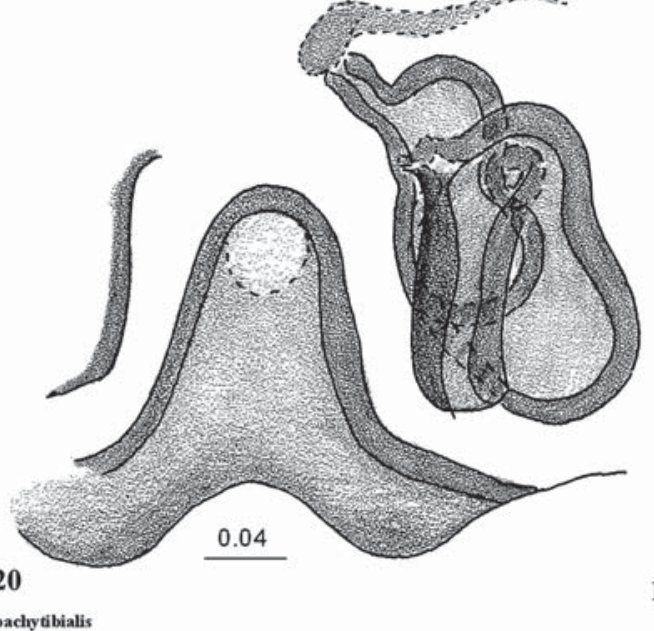

Burmattus pococki

Figs 13-20. General appearance and copulatory organs of Burmattus pachytibialis sp.n. (13-16, 19-20) and B. pococki (17-18): 1314 - general appearance, dorsal and lateral views, $15-18$ - palpus, ventral and lateral views; $19-20$ - epigyne and its internal structures. 13-16, 19-20 from Sumbawa, 17-18 from Myanmar. 17-18 - after Prószyński [1984b].

Рис. 13-20. Общий вид и копулятивные органы Burmattus pachytibialis sp.n. $(13-16,19-20)$ и B. pococki (17-18): 13-14 общий вид, сверху и сбоку , 15-18 - пальпа, снизу и сбоку; 19-20 - эпигина и внутренние структуры. 13-16, 19-20 с о. Сумбава, 17-18 из Бирмы. 17-18 - по Prószyński [1984b].

which stretches more laterally and has a bent tip, claw like.

Body size and proportions. LC $3.80 \mathrm{~mm}$, proportions (shown as ratios to length of carapace) LE 0.53 , HC 0.74, WE1 0.66, WE3 0.68,WC3 0.95, MWC 0.95, LA 1.13, MWA 0.74 . Leg I (as ratio to length of LC) 3.29. Length of legs ( 5 distal segments) in $\mathrm{mm}$ and as ratio to leg I: leg I $12.50=1.00$, leg II $9.20=0.74$, leg III $8.40=0.67$, leg IV $9.50=0.76$. Length of legs order: I, IV, III, II.

Female. Resembles male in general appearance. Epigyne in the Lombok specimens has single, large groove, split anteriorly by triangular elevation, with a pair of small round grooves, presumably the copulatory opening (Fig. 27). Median pocket unusually short and narrow, located approximately $3 / 4$ along the epigynal groove. Shape of spermathecae and ducts (Fig.
28), comparable to specimen from Malacca assumed to be $C$. viduus, illustrated in Andreeva, Kononenko \& Prószyński [1981] (Fig. 29).

Body size and proportions (shown as ratios to length of carapace) length of LC $3.80 \mathrm{~mm}$, LE 0.45 , HC 0.58 , WE1 0.63, WE3 0.68, WC3 0.87, MWC 0.87, LDC 0.74 , LA 1.21, MWA 0.95, Leg I (as proportion to LC) 2.13. Length of legs ( 5 distal segments) in $\mathrm{mm}$ and as ratio to leg I: leg I $8.10=1.00$, leg II $7.60=0.94$, leg III $8.20=1.01$, leg IV $8.60=1.06$. Length of legs order: IV, III, I, II.

REMARK. Closely resembling the type species of the genus - Carrhotus viduus (C.L. Koch, 1846), but males have narrower, more anterior embolus, arising from narrower base and gradually narrowing, with slightly wavy tip. Females of $C$. sundaicus sp.n. have a more prominent constriction in their spermatheca, 

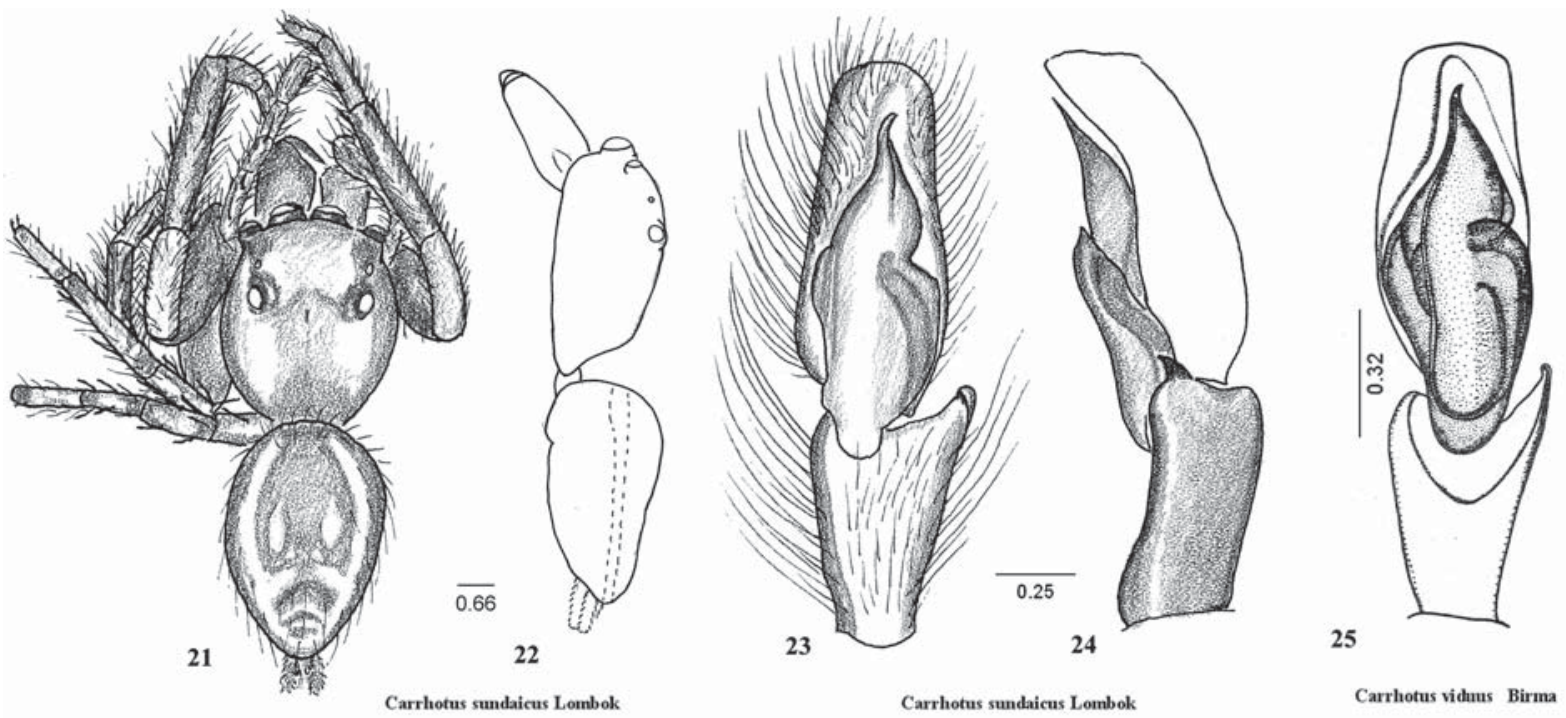

25
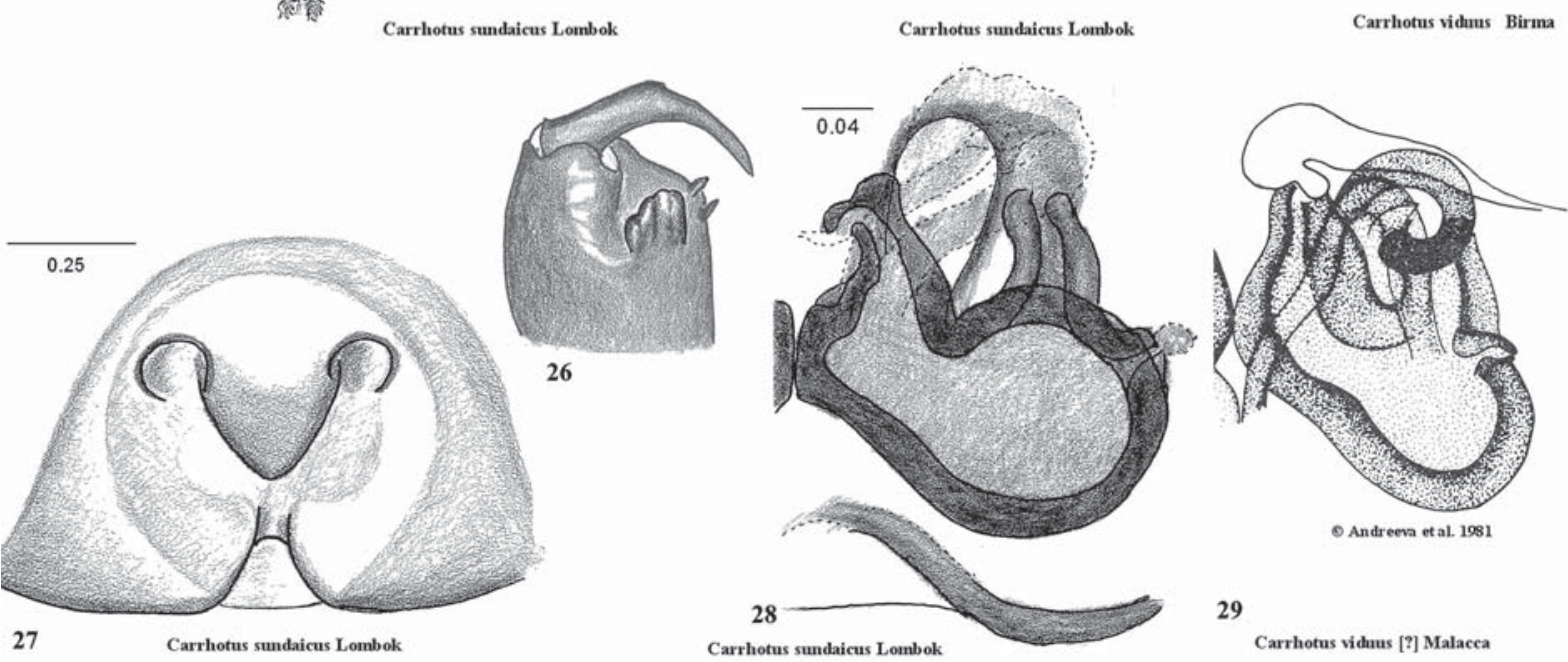

Figs 21-29. General appearance and copulatory organs of Carrhotus sundaicus sp.n. (21-24, 26-28) and C. viduus (25, 29): 21-22 general appearance, dorsal (male) and lateral (female) views, 23-25 - palpus, ventral and lateral views; $27-29$ - epigyne and its internal structures; 26 - cheliceral dentition. 21-24, 26-28 - from Lombok; 25 - from Myanmar; 29 - from Malacca. 25 - after Prószyński [1992], 29 — after Andreeva et al. [1981].

Рис. 21-29. Общий вид и копулятивные органы Carrhotus sundaicus sp.n. (21-24, 26-28) и C. viduus $(25,29): 21-22$ - общий вид, сверху (самец) и сбоку (самка) , 23-25 - пальпа, снизу и сбоку; 27-29 - эпигина и внутренние структуры; 26 - вооружение хелицер. 21-24, 26-28 - с о. Ломбок; 25 - из Бирмы; 29 - с п-ова Малакка. 25 — по Prószyński [1992], 29 — по Andreeva et al. [1981].

that can be regarded as an incipient division into two chambers of unequal size. Other species, including the Palaearctic C. xanthogramma, Oriental C. barbatus and C. sannio [Prószyński, 2010 online] have a short, bent embolus, arising antero-prolaterally, their spermatheca is a single, spherical chamber, while the copulatory ducts are "S" shaped. All species are recognizable by their external appearance: robust, hairy, more or less grayish, with indistinct whitish abdominal spots, similarities in genital organs are sufficient to indicate evolution from a common stem. In spite of genital organs similarities, there are strange differences in the heights and lengths of their carapaces (cf. C. malayanus Prószyński, 1992 [Prószyński, 1992: 167, f. 1-5] from Peninsula Malaya).
DISTRIBUTION. Documented from Indonesia: Lombok Island.

\section{Chrysilla deelemani sp.n.}

Figs 30-35.

MATERIAL. $\sigma^{\top}$ holotype, Lombok: Kute, secondary forest, from foliage, 8-19.01.1990. Leg. S. Djojosudharmo. CDML.

ETYMOLOGY. Species named for the late P.R. Deeleman, husband of Ch.L. Deeleman-Reinhold, who greatly contributed to the creation of her important collection of spiders.

DIAGNOSIS. Closely resembling Chrysilla lauta Thorell, 1887, type species of the genus, in body shape, especially palpus structure (Figs 34-35, 36-37) and chelicerae, with some minor differences in details and 


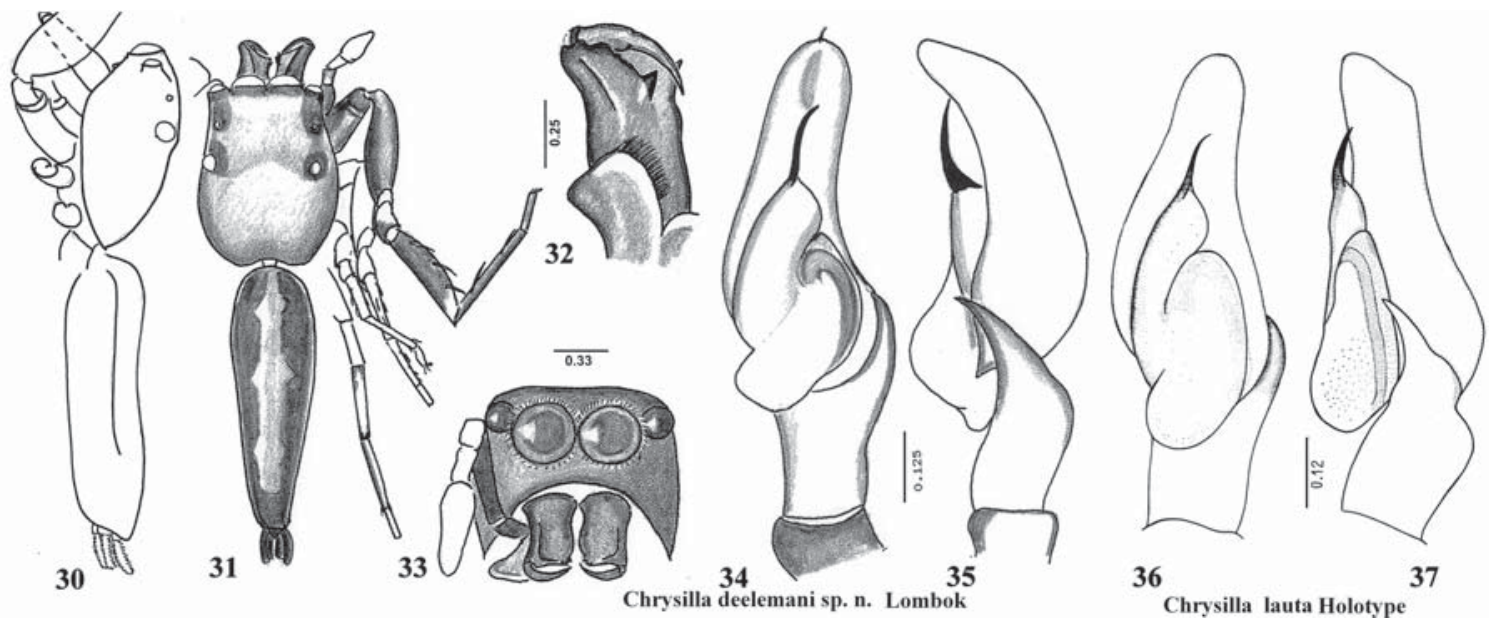

Figs 30-37. General appearance and copulatory organs of Chrysilla deelemani sp.n. (31-35) and Ch. lauta (36-37): 30-31 - general appearance, dorsal and lateral views, 32 - chelicera, posteriôor view, 33 - face, 34-37 — palpus, ventral, dorsal and lateral views. 3135 - Lombok: Kute; 36-37 — from Myanmar. 36-37 - after from Prószyński [1983].

Рис. 30-37. Общий вид и копулятивные органы Chrysilla deelemani sp.n. (31-35) и Ch. lauta (36-37): 30-31 - общий вид, сверху и сбоку , 32 - хелицера, сзади, 33 - «лицо», 34-37 - пальпа, снизу, сверху и сбоку. 31-35 - с о. Ломбок: Ките; 36-37 из Бирмы. 36-37 - по Prószyński [1983].

proportions. However, the dorsal abdominal pattern is the reverse of that in other species: light median streak and laterall dark areas (Fig. 31).

DESCRIPTION. Carapace low, twice as long as eye field, gently sloping behind eye field, broader behind eyes III (posterior median). Anterior lateral eyes aligned along dorsal rim of anterior median eyes, their diameter two times smaller (Fig. 33). Abdomen low and long, narrower than carapace. Dorsal coloration of abdomen dark with light median streak broadened angularly in three places (Fig. 31), posteriorly not reaching spinnerets, sides lighter. In Ch. lauta the median streak is distinctly broader. Spinnerets elongate and dark. Chelicerae elongate (Fig. 32), directed diagonally forwards, slightly diverging distally, with prominent retrolateral tooth. Palpus resembling that of Ch. lauta, with elongate cymbium, bulbus narrow with embolus base prominent and stretching forward, embolus median, somewhat longer than in other species, apically gently bent, posterior lobe of the bulbus drawn diagonally (Fig. 34). Tibial apophysis bent to form a semicrescent, sharply pointed, without distinct swelling on the dorsal edge (Figs 35, 37). Female unknown.

REMARK. Genus Chrysilla is insufficiently known. Out of 7 nominal species, only two have documentation permitting recognition (Chrysilla lauta Thorell, 1887 and Ch. versicolor (C.L. Koch, 1846)), three others require revision of the types (Ch. delicata Thorell, 1892, Ch. doriai Thorell, 1890 and Ch. pilosa (Karsch, 1878)), two species are apparently misplaced (Ch. albens Dyal, 1935 and Ch. kolosvaryi Caporiacco, 1947) [Prószyński 2010 online].

DISTRIBUTION. Documented from Indonesia: Lombok Island.

Genus Cosmophasis Simon, 1902

Type species Cosmophasis thalassina (C.L. Koch, 1846).
REMARK. The genus Cosmophasis contains 45 nominal species (33 with documentation of diagnostic drawings, of which 15 are Asian, 7 Australian, 11 Pacific Islands; 6 African species - are not congeneric). They are usually brightly colored (only a few species have a black body), covered with iridescent, light reflecting scales over the carapace, abdomen and legs; scales are arranged in contrasting transverse or diagonal bands, longitudinal streaks, or oval spots on various parts of the body. Similar iridescent coloration also occurs in other genera, including Siler Simon, 1889 (see below), which can be, and often are mistaken, as Cosmophasis. Color pattern of Cosmophasis species may serve as a basis for identification [see Prószyński 2010 online], as in the identification of butterflies, providing that the diversity of that character is assessed and correlated alongside a study of the genital organs. That has not yet been done, and provisional specific names listed under pictures in the general literature can be misleading. Although brightly colored (iridescent species of Cosmophasis are obvious in the field), they have not previously been reported from the Lesser Sunda Islands. The Deeleman collection contains numerous and varied, unidentified specimens from Bali, Lombok, Sumba and Sumbawa, one of which is described as new below. Three species from Bali were photographed by D. Knowles [see at http: //www.gsdsalt.miiz.waw.pl/salticidae.php].

\section{Cosmophasis valerieae sp.n.} Figs 38-41, 44-46.

MATERIAL. + holotype, $\sigma^{\top}$ allotype, $1+$ paratype, Sumbawa: Samokat, $20 \mathrm{~km}$ of Sumbawa Besar, $480 \mathrm{~m}$., secondary forest, 3.01.1990. Leg. S. Djojosudharmo. CDML.

COMPARATIVE SPECIMENS. O" "Cosmophasis thalassina (C.L. Koch, 1846), Holotypus, Bintang, Hinterindien. Roetger". ZMB 1747 


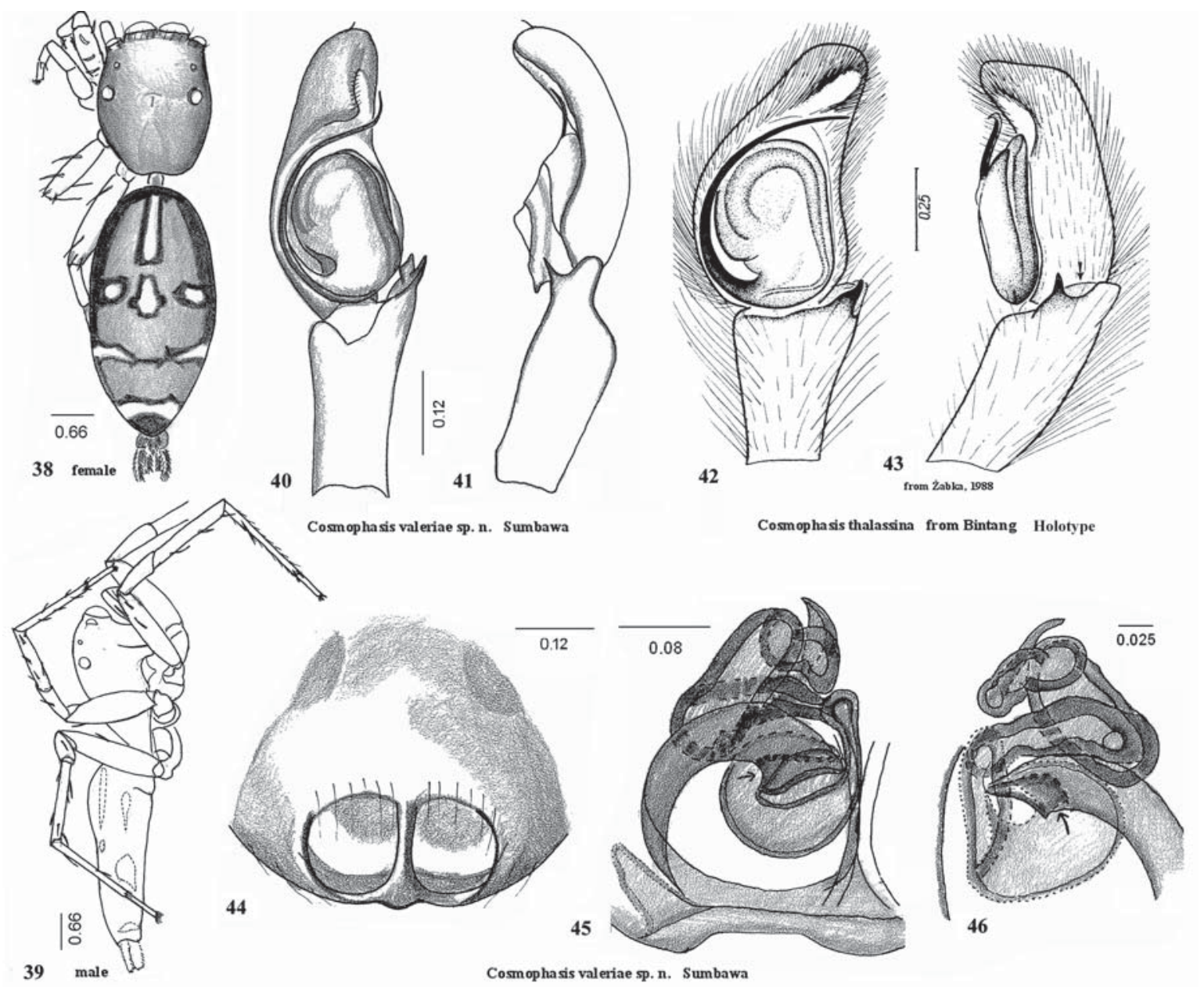

Figs 38-46. General appearance and copulatory organs of Cosmophasis valerieae sp.n. (38-41, 44-46) and Cosmophasis thalassina (42-43): 38-39 - general appearance, dorsal and lateral views; 40-43 — palps, ventral and lateral views, 44 — epigyne; $45-46$ internal structures of epigyne, ventral and dorsal views. 42-43 - from Bintang - holotype, palpal organ, ventral and lateral views (4243, from Żabka [1988]). 38-41, 44-46 — from Sumbawa.

Рис. 38-46. Общий вид и копулятивные органы Cosmophasis valerieae sp.n. (38-41, 44-46) и Cosmophasis thalassina (42-43): 38-39 - общий вид, сверху и сбоку; 40-43 - пальпы, снизу и сбоку , 44 - эпигина; 45-46 - внутренние структуры эпигины, снизу и сверху. 42-43 - с о. Бинтанг — голотип, пальпа, снизу и сбоку (42-43, по Żabka [1988]). 38-41, 44-46 — с о. Сумбава.

ETYMOLOGY. Species named for the prominent Australian arachnologist Dr. Valerie Todd Davies.

DIAGNOSIS. Palpus (Figs 40-41) differs from other Cosmophasis species by proportions, epigyne and especially its internal structure are specific (Figs 44-45).

DESCRIPTION. Male allotype. Color pattern deteriorated, but different from female. Palpus shape and proportions, with long embolus arising posteriorly and tibial apophysis with sharp ventral pin and rounded dorsal lobe (Figs 40-41) resembling an unnamed species in Davies \& Żabka [1989], as well as the type species of the genus (Figs 42-43) - C. thalassina (C.L. Koch, 1846) (following Żabka [1988], not Prószyński [1984b: 23, f. unnumbered]). Length of carapace 2.90, proportions LE 0.48 , HC 0.48 , WE1 0.63 , WE3 0.65, WC3 0.81, MWC 0.82, LA 1.45, MWA 0.52 , leg I as proportion of LC 2.47. Length of legs ( 5 distal segments) in $\mathrm{mm}$ and as ratios to length of leg I: leg I $7.16=1.00$, leg II $7.60=1.06$, leg III $7.30=1.02$, leg IV $7.60=1.06$. Length of legs order: IV=II, III, I.

Female holotype. Color pattern (Fig. 38) iridescent orange, with streaks and bands of white scales, delimited by black, resembling that shown in the photograph of C. bitaeniata [?] in Brunet [1996: 120], from Australia on which, however, the first abdominal band is continuous, not divided into three parts. Relatively simple spermathecae and ducts (Figs 45-46) are developed anteriorly into two transverse, duct like chambers, and two connecting chambers running parallel to the main axis. Similar structures in C. marxi (Thorell, 1890) are shifted posteriorly in relation to the copulatory opening. In C. muralis Berry, Beatty, Prószyński, 1997 from Caroline Is. the spermatheca is reduced to a single semicircular broad duct, developed behind the copulatory opening. 
Length of Carapace 2.37, proportions LE 0.47, HC 0.50, WE1 0.66, WE3 0.68, WC3 0.74, MWC 0.74, LDC 0.68, LA 0.137, MWA 0.63, leg I as proportion of LC 1.90. Length of legs (5 distal segments) in $\mathrm{mm}$ and as ratios to length of leg I: leg I $4.50=100$, leg II $4.30=0.95$, leg III $4.87=1.08$, leg IV 5.69=1.26. Length of legs order: IV, III, I, II.

REMARK. Resembles $C$. thalassina, type species of the genus, in palpus shape and structure, especially shape and position of the embolus, as well as by the short, sclerotized, reduced ventral ramus of the tibial apophysis, but with distinct differences in details. In the majority of all 33 species from Asia, Australia and the Pacific Islands, for which diagnostic documentation exists, the palps represent variation on the same basic plan. Remarkably similar, although clearly different, is the unnamed species of Cosmophasis from Australia, illustrated by Davies and Żabka [1989].

DISTRIBUTION. Documented from Indonesia: Sumbawa Is.

\section{Genus Cytaea Keyserling, 1882}

Type species C. alburna Keyserling, 1882 from Australia.

DESCRIPTION. Body stout, covered by light-reflecting scales, medium high, with carapace broad, semicircular posteriorly, eyefield broader than long, rectangular. Carapace with characteristic white band along margins and central light spot near fovea, broad diamond shaped. Abdomen about as long as carapace, but narrower (Figs 47-48). Palpal organ of the Euophryinae type, with broad bulbus, meandering seminal receptacle duct, embolus forming a large, flat coil in anterior part of bulbus [species with a small embolic coil should presumably be reclassified]; epigyne with two large oval grooves, characterized by complicated loops of sclerotized ducts and small, globular spermathecae. Copulatory openings sometimes containing an embolic plug (broken tip of embolus left behind post-copulation). Females resemble the genus Xenocytaea Berry, Beatty \& Prószyński, 1998 from Fiji, which differ by having broad, sclerotized hood, covering the anterior part of the epigyne, and rather simple spermathecae and ducts.

REMARK. The synonymy of C. alburna with Plexippus severus Thorell, 1881, claimed by Żabka [1991], is not confirmed yet by any documentation. The genus consists of 57 nominal species, only 27 with documented reference figures; the internal structure of the epigyne is known only for 10 species. This genus requires revision.

DISTRIBUTION. According to current data the genus is most speciose in continental Australia and New Guinea, as well as islands located on the Australian tectonic plate e.g., the Aru Islands. It is also reported from Pacific Islands, Indonesia, Singapore and Malaysia. More northern reports appear to be derived from misidentified specimens. Seven species were reported from Indonesia, but only 4 of them with diag- nostic documentation, 2 nominal species were reported from Lombok, 3 from Java, 2 from Sumatra and 1 from Borneo; no Cytaea were described from Sumbawa. The collection contains numerous, varied specimens of Cytaea from the Lesser Sunda Islands, one of which is described as new below. Two species from Bali were photographed by D. Knowles [http: //www.gsd-salt. miiz.waw.pl/specimen.php?id=11185].

\section{Cytaea whytei sp.n.}

Figs 47-53.

MATERIAL. 9 holotype (with epigyne detached and cleared), $\sigma^{7}$ (with palpus detached) allotype, - paratypes 18 ㅇ, $9 \sigma^{7} \sigma^{7}, 4$ imm, "Samokat, $40 \mathrm{~km}$ fr. Sumbawa Besar, secondary forest. 19.01.1990. Leg. S. Djojosudharmo". CDML.

ETYMOLOGY. Species named after Mr. Robert Whyte, Australian arachnologist and photographer.

DIAGNOSIS. Epigyne and its internal structures are comparable with those of $C$. sinuata (Doleschall, 1859) from Ambon and C. nimbata (Thorell, 1881) from New Guinea, but differs in fine details. The palpus is built according to the same plan, but is narrower.

DESCRIPTION. Male. Carapace as broad as long, posterior outline semicircular, eyefield slightly longer than thorax, rectangular, wider than long. A striking band of white scales is present along ventral edge of carapace and a broad, diamond-shaped spot on the anterior part of the thorax, with a sharp angle at the fovea (Fig. 47). Abdomen with two pairs of diagonal light spots laterally. Cymbium and bulbus narrow, narrower than in C. sinuata from Ambon. Basal coil of embolus arranged flatly on ventral apical surface of bulbus, occupying approximately $2 / 3^{\text {rd }}$ of its width (Fig. $50)$. Anterior bend of seminal duct broad and relatively shallow. Tibial apophysis about $1 / 6^{\text {th }}$ the length of cymbium, with dorsal edge inclined, its tip bent ventrally (Fig. 51). Retrolateral tooth on chelicera broad and blunt (Fig. 49). Legs long and moderately robust.

Female. Externally resembles male (Fig. 48). Epigyne with two large, oval grooves with slightly sclerotized rims (Fig. 52), copulatory openings small, partly hidden under anterior rim of the groove. Copulatory duct long with sclerotized walls, running along the whole axis of external groove and forming two coils one smaller anteriorly, with prominent conical scent gland near copulatory opening, and a second coil posteriorly, longer, joining semi-oval spermatheca, the latter with oval depression around set of nutritive pores, close to beginning of fertilization duct (Fig. 53).

DISTRIBUTION. Documented from Indonesia: Sumbawa. Numerous Cytaea sp. specimens from other Lesser Sunda Islands are kept in the Deeleman collection.

Gen. Emertonius Peckham \& Peckham, 1892 Figs 164-167, 169-171.

Type species Emertonius exasperans Peckham \& Peckham, 1892 - from Java. 

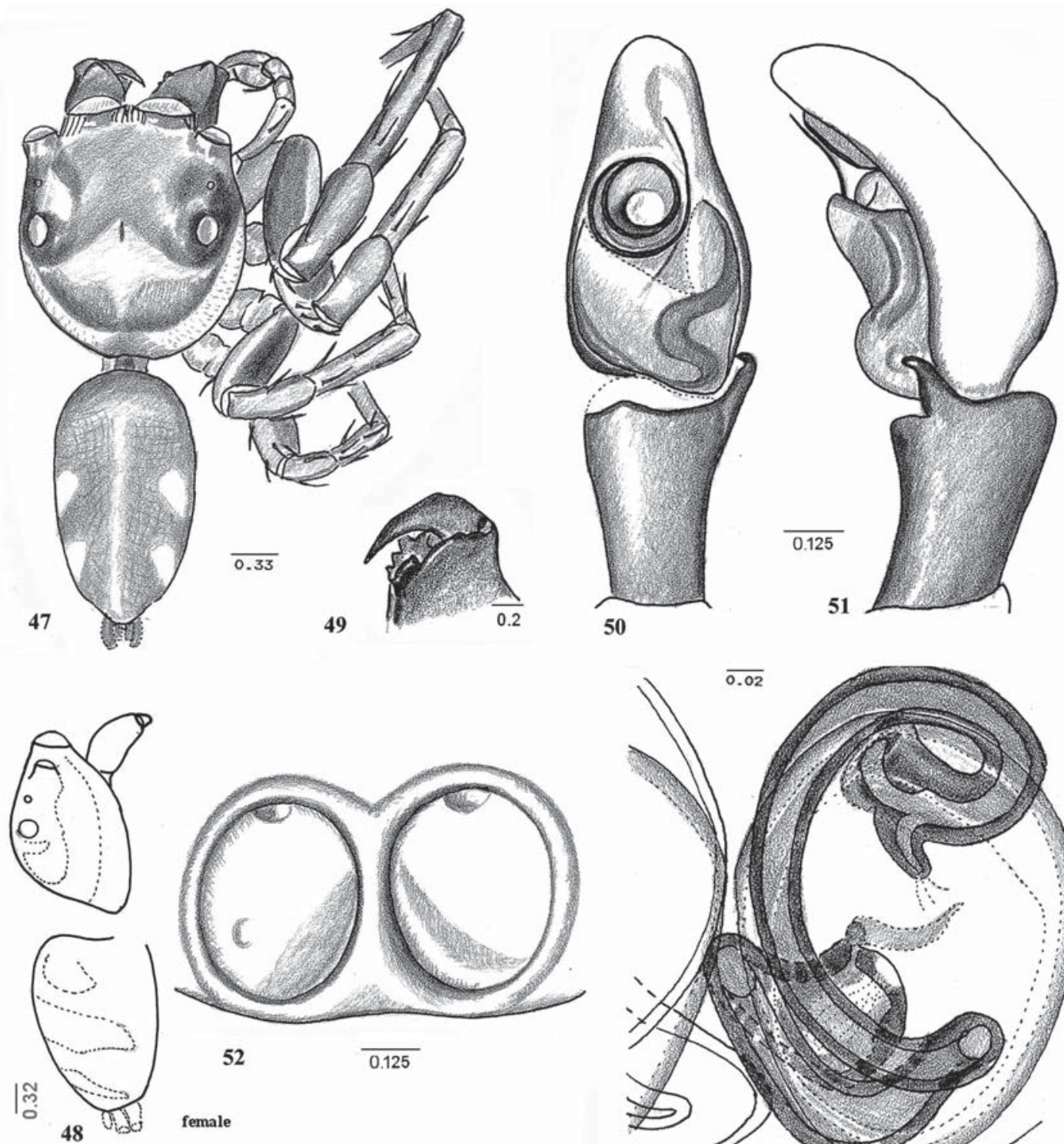

Cytaea whytei Sumbawa

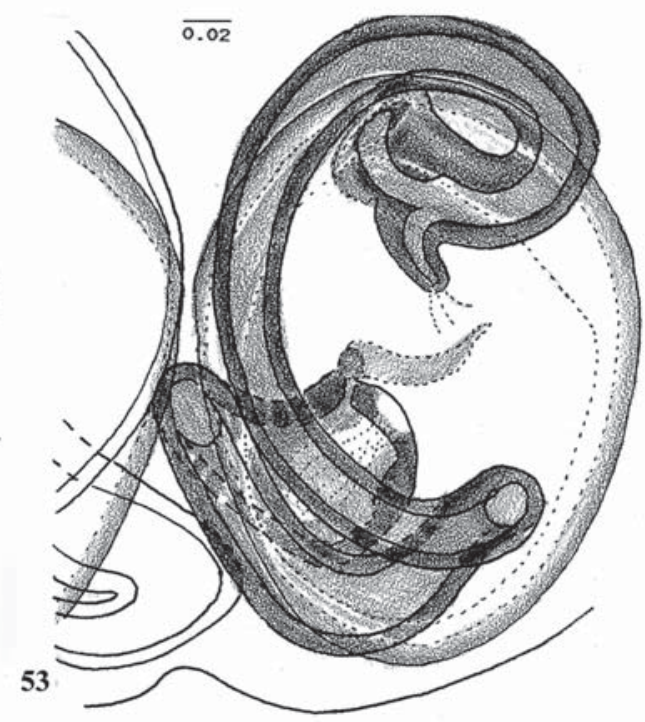

Figs 47-53. General appearance and copulatory organs of Cytaea whytei sp.n. from Sumbawa: 47 - general appearance of male, dorsal view; 48 - general appearance of female, lateral view; $49-$ cheliceral dentition, posterior view; 50-51 - palpus, ventral and lateral views; 52 - epigyne; 53 - internal structures of epigyne.

Рис. 47-53. Общий вид и копулятивные органы Cytaea whytei sp.n. с о. Сумбава: 47 - общий вид самец, сверху; 48 - общий вид самка, сбоку; 49 - вооружение хелицер, сзади; 50-51 - пальпа, снизу и сбоку; 52 - эпигина; 53 - вульва.

DESCRIPTION. A Myrmarachninae genus, differing from Myrmarachne McLeay, 1839 by its unique color pattern and in not having the body constricted (Fig. 164). Carapace flattened but high, with posterior wall of thorax almost vertical and concave; petiolus visible from above but short. Tibial apophysis gently bent but not twisted. The spermathecae are club-like, their proximal part duct-like, narrow and gently bent, the distal chamber is spherical and enlarged (Fig. 167). The copulatory ducts are membranous and form a broad loop, beginning from the distinct and relatively wide copulatory openings, located near the center of the "windows". The rims of these openings are thickened; in the Bali specimen they are irregularly sclerotized.

REMARK. Wanless [1978: 235] was uncertain where to classify E. exasperans, the type species of the genus, and with some hesitation he transferred it to Myrmarachne, seconded recently by Edwards \& Benjamin [2009] in their cladogram. However, the internal structure of the epigyne (Fig. 167) and especially the color pattern visible on photographs of a living specimen by Mr. D. Knowles [http: //www.gsd-salt.miiz. 
waw.pl/specimen.php?id=11184], also marked on Fig. 164 , exclude such a possibility. At present, the genus consists of a single described species and two forms not yet named but listed below.

This example illustrates the inadequacy of extensive synonymization of genera of Myrmarachninae, based on interpretations of drawings from the literature, rather than intensive comparative research and good documentation. The preliminary data suggest the need to split Myrmarachne into more homogenous groups, rather than lumping the species together.

DISTRIBUTION. Documented from Bali, Java, Borneo and Palawan.

Emertonius exasperans Peckham \& Peckham, 1892 comb. reinstated

$$
\text { Figs 164-171. }
$$

Emertonius exasperans Peckham \& Peckham, 1892: 54, pl. 4, f. $8\left(\sigma^{7}\right)$.

$$
\text { Emertonius exasperans: Simon, 1901a: 504, f. } 595 .
$$

Myrmarachne exasperans: Wanless, 1978b: 235, f. 1A-F; 2A$\mathrm{E}\left(+\mathrm{O}^{\mathrm{T}}\right)$.

Myrmarachne exasperans: Edwards \& Benjamin, 2009: 22

MATERIAL. O’ $q$ “Emertonius exasperans Peckh. TYPE. Java, Bantam [=Bentam Prov.]. Workman No, I. 66: Lectotype designated by Wanless". MCZ Harvard.

$\sigma^{\top}$ Emertonius sp. Bali: Alas Kedaton Photograph by Mr. D. Knowles, http: //www.gsd-salt.miiz.waw.pl/salticidae.php?adres= img.php?id=15999. Specimen was not collected, I have no license to reproduce photo here.

"Emertonius exasperans Bali: Ambengan, secondary forest, 19-31. 01.1990. Leg. S. Djojosudharmo.” CDML Photographs: see http: //www.gsd-salt.miiz.waw.pl/salticidae.php?adres=img.php ?id=15999.

DESCRIPTION. Male. Carapace narrow, high, dorsally almost flat, the posterior declevity almost vertical and concave (Figs 164-166). Dorsal surface covered by two broad, brown streaks, separated by a thin yellow median line. Lateral surfaces yellow, clypeus apparently yellow. Lower margin of sides brown, irregular, ventral edge of carapace yellow. Petiolus short, but visible from above. Palpus of presumably the Java specimen was illustrated by Wanless [1978b: f. 1A-F].

Abdomen as narrow and long as the carapace, black. Posterior tip of abdomen yellow, occupying 0.35 its length, anterior edge triangular medially. The most striking character of the species consists of five narrow yellow "petals" - club like spots radiating over the anterior 0.4 of the abdomen (two lower petals are actually the edges of larger, lower yellow areas).

Chelicerae enlarged, dorsally flat, as in some $M y r-$ marachne, iridescent dark blue anteriorly, posteriorly violet. Legs brown, with femora I-IV darker brown, the remaining segments light brown, except for tibia I which is dark iridescent blue.

Female. Body shape is shown in Figs 170-171. Internal structures of epigyne are shown in Fig. 167. Cheliceral dentition is shown in Fig. 169. Photographs of the specimen from Bali are available at http: //www. gsd-salt.miiz.waw.pl/salticidae.php?adres=img.php? $\mathrm{id}=15999$.
REMARK. Wanless [1978b] designated the $q$ from the original series of specimens as the lectotype, but this was not mentioned in the original description, which contained only description of the $\sigma^{7}$. The geographical range of this species given by Wanless as Java and Philippines is most probably a mistake, resulting from misidentification of the congeneric Palawan specimen. It is not clear whether the male drawn by Wanless came from Java or Palawan, and that can only be clarified following study of fresh specimens from both islands.

NOTE. Examination of the vial containing the lectotype specimen in 2010 by Dr. G.B. Edwards (personal communication) disclosed that the original epigyne of the lectotype is missing from its microvial and was replaced by an epigyne (with soft tissues not cleared) from an unknown species of Myrmarachne, shown in Fig. 168.

DISTRIBUTION. Documented from Indonesia: Java and Bali.

\section{Emertonius sp. from Sabah}

MATERIAL. + Emertonius sp (labelled as Myrmarachne exasperans) Borneo: Sabah: Tenom,: Rafflesia Garden at Perkasa Hotel. Set of photographs by Mr. P. Koomen (see http: //www.gsdsalt.miiz.waw.pl/salticidae.php?adres=specimen.php?id=11641). Sabah spider collection of P. Koomen, Leeuwarden, the Netherlands (to become part of the Borneensis Collection of the University Malaysia Sabah, Kota Kinabalu, Sabah-Malaysia).

DESCRIPTION. The species is unmistakably related to E. exasperans, with comparable coloration and body shape, but there are only 2 dorsal "petal"-like spots, whitish yellow, on anterior of abdomen, Epigyne resembling $E$. exasperans, but spermathecal ducts distinctly thinner, they are not gradually thickened joining anterior spherical bodies, posterior ends of ducts stretched distinctly sidewards.

REMARK. This set of photographs is sufficient to describe the species as a new one. Note the perfect presentation of the epigyne and its internal structures. It is perhaps the best example of new techniques for taxonomic study, available to local amateurs, even without access to specialized laboratory equipment.

DISTRIBUTION. Documented from Malaysia: N Borneo: Sabah.

\section{Emertonius sp. from Palawan}

MATERIAL. O' "Philippines: Palawan Manialingajan Pinigisan: 600 m. 12.08.1961. Noona Dan Exp. BMNH.

REMARK. Listed by Wanless [1978b: 235, f. 1AF] as $\sigma^{\top}$ Myrmarachne exasperans from Palawan, it presumably belongs to the genus Emertonius, but there are no reasons to consider it conspecific with the type species. Because it is not clear whether the description by Wanless concerns the Palawan or the Javan specimen, we abstain from naming this species.

DISTRIBUTION. Listed from the Philippines: Palawan. 


\section{Epeus sp. from Bali}

MATERIAL. $\sigma^{\top} \bigcirc$ Bali: Alas Kedaton; $\sigma^{7}$ from Java: Jakarta. All 3 photographs by Mr. D. Knowles [http: //www.gsdsalt.miiz.waw.pl/specimen.php?id=11188], no specimen collected.

REMARK. The available photographs of Epeus spp. from Java, Bali and also Singapore, [http: //www. gsd-salt.miiz.waw.pl/salticidae.php] disclose a color pattern diversity amounting to species specific differences. It is apparent that the photograph of the male Epeus sp. from Bali is of a different species than $E$. flavobilineatus (Doleschall, 1859) from Java (both photographs by D. Knowles). There is also a nomenclatorical problem: which of these species can be considered Epeus flavobilineatus? They differ also from the photographs of Epeus spp. from Singapore by F.J. Murphy and J. Koh. The type specimen of Epeus flavobilineatus does not exist and the original description is limited to a female, mentioning only a green central band on the abdomen and two marginal yellow streaks (as on the photo by D. Knowles from Bali). This calls for the designation of a neotype from Java, following a revision of the species occurring in that area. Bali.

DISTRIBUTION. Documented from Indonesia:

\section{Euryattus [?] junxiae sp.n.}

Figs 54-58.

MATERIAL. $q$ holotype, $\sigma^{7}$ allotype, Semokat, $20 \mathrm{~km}$ of Sumbawa Besar, 480 m.a.s. Leg. S. Djojosudharmo. CDML.

ETYMOLOGY. Species named after Junxia Zhang, arachnologist and author of valuable papers on Salticidae.

DIAGNOSIS. Epigyne differs from other species of Euryattus in having a reduced septum between the membranous windows and in the proportions of the sclerotized copulatory duct to the spermatheca (Figs 57-58); also in details of the palpus structure.

DESCRIPTION. Male. Carapace high, with eyefield slightly narrowing posteriorly, flat surface ends slightly behind eyefield and passes into a steep posterior slope. There is a large light spot on the thorax (Fig. 54). Abdomen oval, narrowing posteriorly, slightly shorter than carapace, with remnants of dark spots over light background, and distinct, sparse dark bristles. Palpus differs in proportions from other species, with embolus almost as long as tibia. Bulbus relatively short in comparison with other Euryattus species (Figs 5556), meandering loops of the sperm reservoir more tightly bent, base of embolus triangular, not round, its length equal to that of bulbus. Length of tibial apophysis equal to half length of cymbium and only slighthly shorter than tibia, moderately narrow and slightly inclined downwards, especially in apical half.

Female. Body resembling male. Epigyne difers from other species of the genus by having a reduced septum separating the anterior windows. Internal structures more compact than in other species, with ducts entirely reduced and copulatory opening leading almost directly to spermatheca, which has the form of a broad, tight letter "U", armature of the scent gland opening very indistinct, close to rim of copulatory opening (Figs 5758).

REMARK. This species is of uncertain generic position, but is closest to the widespread Indo-Australasian genus Euryattus Thorell, 1881, which it resembles in the shape and proportions of the body, as well as by palpus shape; see type species of the genus Euryattus porcellus Thorell, 1881 from New Guinea (Figs 5961). However, the epigyne and its internal structures are different.

DISTRIBUTION. Documented from Indonesia: Sumbawa Island.

\section{Evarcha kochi Simon, 1902 comb. reinstated} Figs 62-69.

E. kochi Simon, 1902: $397\left(\sigma^{7}\right)$.

E. kochi: Prószyński, 1984b: $49\left(\sigma^{7}\right)$.

E. flavocincta Żabka 1985: 224, f. 193-196 ( $q$ synonym, misidentified).

MATERIAL. 1 \% , 3 우 Evarcha kochi Lombok: Kute, secondary forest, litter, $100 \mathrm{~m}, 8-18.01 .1990$. Leg. S. Djojosudharmo. CDML.

DIAGNOSIS. Male and female similar to Evarcha reiskindi Berry, Beatty \& Prószyński, 1996 from the Caroline Islands: Palau Island, particularly in spermathecae (Figs 69-70). However, they differ in fine details. In E. kochi males the tibial apophysis is narrower and longer, slightly wavy, and the embolus is longer. There are striking differences in internal structures of the epigynes between $E$. kochi (Fig. 69) and $E$. flavocincta (Fig. 72) and several other related species, which have long copulatory ducts, twisted into several coils, resembling a drawn out, irregular spiral.

DESCRIPTION. Male. Body does not differ from generalized salticid, with abdomen narrow oval, about as long carapace, but distinctly narrower (Figs 62-63). Abdomen with light median streak, broad, constricted at one third of its length, but with transverse expansion within that constriction.

Palpus (Figs 64-65) does not differs significantly from Simon's specimen from Lombok [Prószyński, 1984b], which, however, has a broader apophysis (Figs 66-67). Bulbus is circular and broad, as in several SE Asian Evarcha (E. bulbosa Żabka, 1985, E. pococki Żabka, 1985, E. pulchella Thorell, 1895), narrow embolus encircling half of bulbus. Measurements and proportions. Length of carapace 2.50, proportions LE 0.40, HC 0.50, WE1 0.68, WE3 0.68, WC3 0.95, MWC 0.95 , LDC -, LA 1.13, MWA 0.74, leg I as proportion of LC 1.71. Length of legs (5 distal segments) in $\mathrm{mm}$ and as ratios to length of leg I: leg I $4.55=100$, leg II $4.18=0.92$, leg III - , leg IV $4.62=1.01$. Length of legs order IV, -, I, II.

Female. Epigyne externally (Fig. 68) resembles several SE Asian species, slightly differing in details of shape of posterior edge and proportions of grooves and septum (Fig. 71). Internal structures however, are very different and consist of broad, short and almost straight ducts, and with small, globular spermatheca (Fig. 69). 


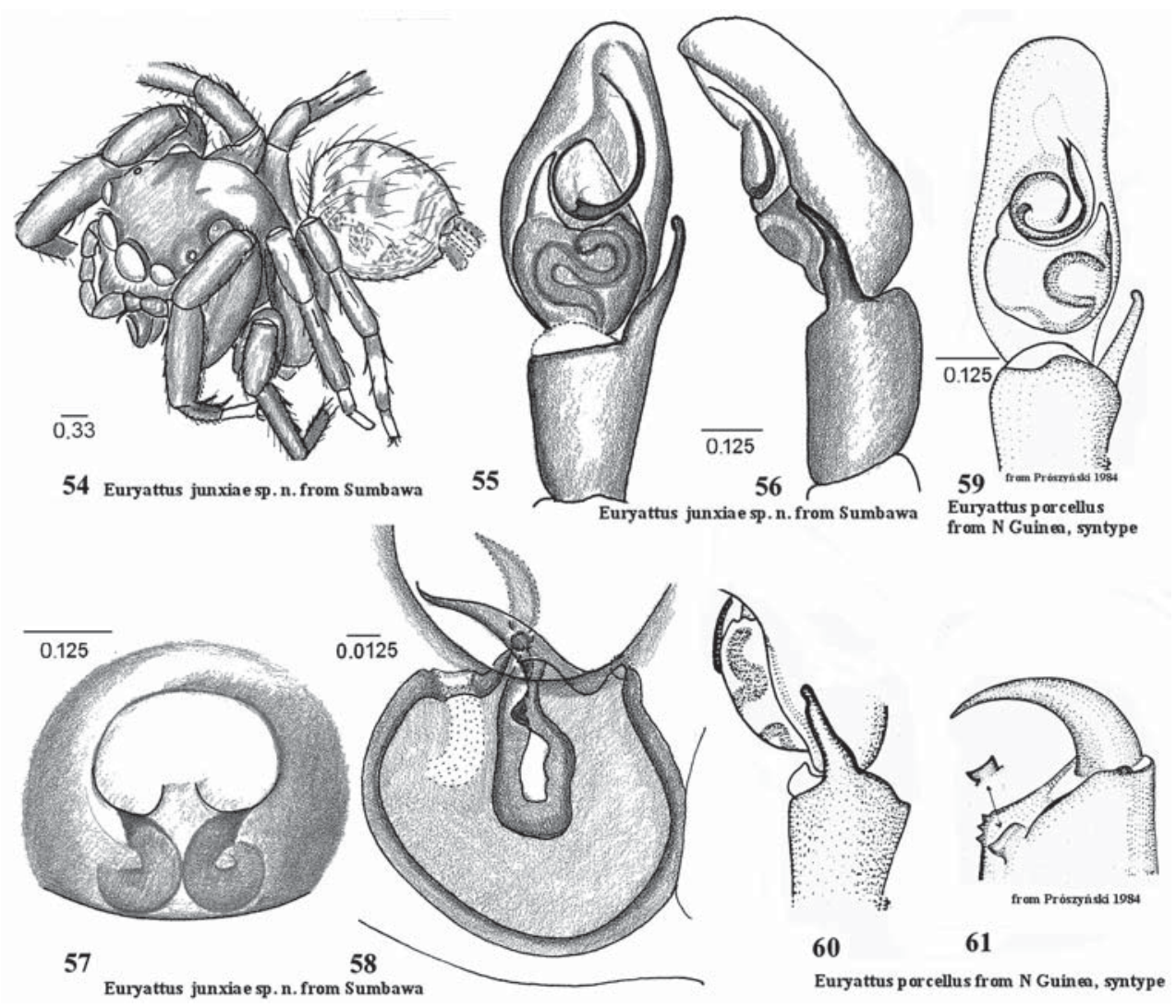

Figs 54-61. General appearance and copulatory organs of Euryattus junxiae sp.n. (54-58) and Euryattus porcellus syntype (59-61): 54 - general appearance; 55-56 - palpus, ventral and lateral views; 57-58 - epigyne and its internal structures; 61 - cheliceral dentition (57-58). 59-61 - from New Guinea; 54-58 — from Sumbawa. 59-61 — after Prószyński [1984b].

Рис. 54-61. Общий вид и копулятивные органы Euryattus junxiae sp.n. (54-58) и синтип Euryattus porcellus (59-61): $54-$ общий вид; 55-56 - пальпа, снизу и сбоку; 57-58 - эпигина и внутренние структуры; 61 - вооружение хелицер (57-58). 59-61 из Новой Гвинеи; 54-58 - с о. Сумбава. 59-61 - по Prószyński [1984b].

Measurements and proportions. Length of carapace 2.80 proportions LE 0.43 , HC 0.46 , WE1 0.64 , WE3 0.66, WC3 0.87, MWC 0.87, LDC 0.74, LA 1.21, MWA 0.95 , leg I as proportion of LC 2.13. Length of legs ( 5 distal segments) in $\mathrm{mm}$ and as ratios to length of leg I: leg I 4.80=100, leg II 4.70=0.98, leg III 5.70=1.19, leg IV 5.50=1.14. Length of legs order III, IV, I, II.

REMARK. The male and female are congeneric with E. falcata (Clerck, 1757), the type species of the genus Evarcha Simon, 1902, and with other species, particularly of the group E. flavocincta. However, there are differences in proportions of the epigyne and palpus between E. kochi and E. flavocincta (C.L. Koch, 1846), and striking differences, previously unknown, in the shape of the spermathecae and the copulatory ducts. So their synonymy [Żabka, 1985] is hereby reversed and the species $E$. kochi reinstated. It appears that E. flavocincta occurs both in Java and Lombok (in the latter together with $E$. kochi).

DISTRIBUTION. Documented from Indonesia: Java and Lombok Island.

Harmochirus brachiatus (Thorell, 1877) Figs 73-78
Ballus brachiatus Thorell, 1877: $626\left(0^{7}\right)$.

Harmochirus malaccensis Simon, 1885: $441\left(\sigma^{7}\right)$.

Harmochirus nervosus Thorell, 1890b: $68\left(\sigma^{7}\right)$.

Harmochirus brachiatus: Simon, 1903: 867, f. 1024-1026 (○'). Harmochirus brachiatus: Prószyński, 1984b: 55-56 ().

Harmochirus brachiatus: Prószyński, 1987: 59, 108 (○ㅇ)

Harmochirus brachiatus: Davies \& Żabka, 1989: 214, P1. 22 $\left.\left(\mathrm{O}^{\top}+\right)^{2}\right)$

Harmochirus brachiatus: Barrion \& Litsinger, 1995: 90, f. 46a-g, 47a-j $\left(0^{7}+\right)$.

Harmochirus brachiatus: Logunov, Ikeda \& Ono, 1997: 5, f. 9-10 ( $\left.\bigcirc^{\top}+\right)$

Harmochirus brachiatus: Logunov, 2001: 250, f. 2, 169-174, 177-191, 247, 265 ( ${ }^{7}$ O)

Harmochirus brachiatus: Peng et al., 2002: 8, f. 30-35 ( $\left.0^{7}\right)$.

Harmochirus brachiatus: Cho \& Kim, 2002: 96, f. 15-16,

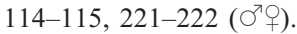

Full list of synonyms and citations - see Platnick [2010] and Prószyński [2010].

MATERIAL. 1 , $1 \sigma^{r}$ Harmochirus brachiatus W Bali, Ambengan, sec. forest, 1. litter. Leg. S. Djojosudharmo. CDML.

DIAGNOSIS. External appearance typical for the genus, palpus and epigyne drawn from the type specimen of the synonymous $H$. malaccensis Simon, 1885 as shown by Prószyński [1987].

DESCRIPTION. Male. General appearance characteristic for the genus (Figs 73-74), with flat surface of the carapace limited to the eyefield, thoracic part 

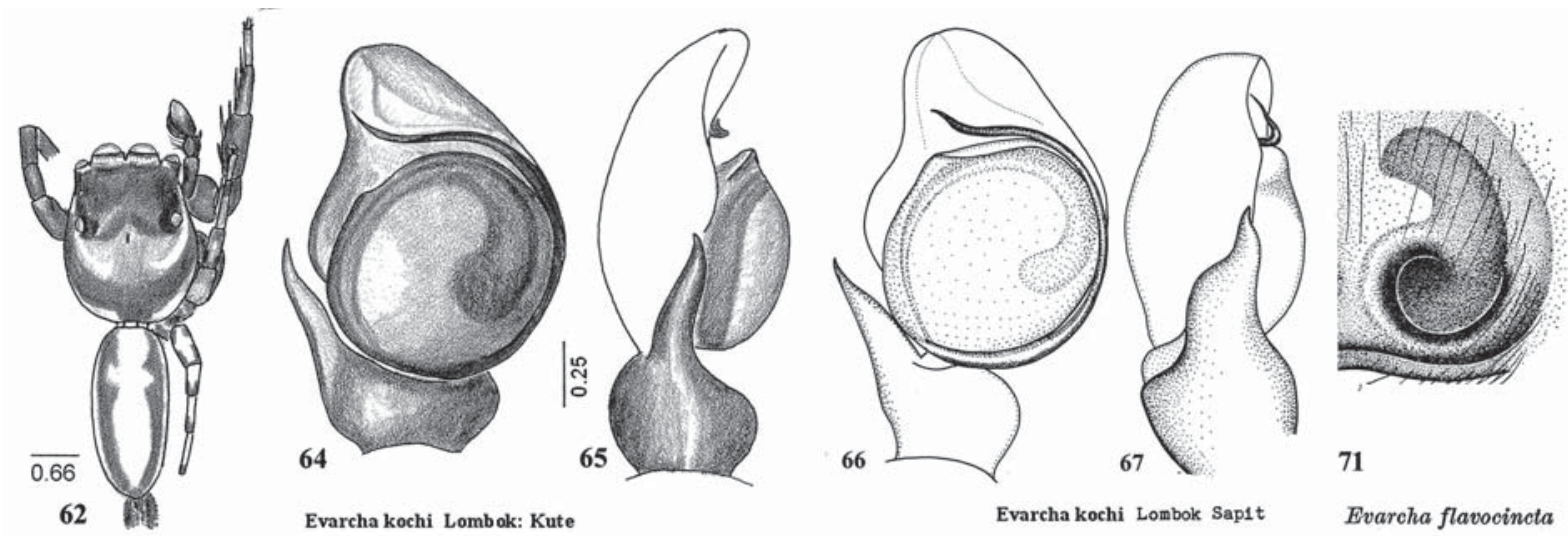

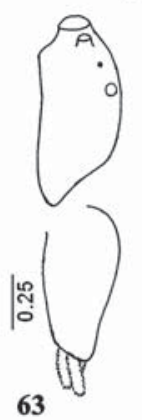

63

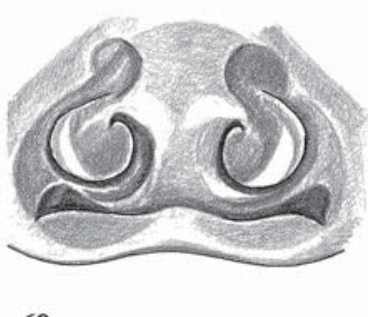

68

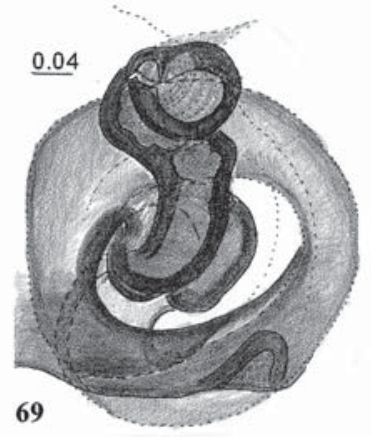

69

Evarcha kochi Lombok: Kute

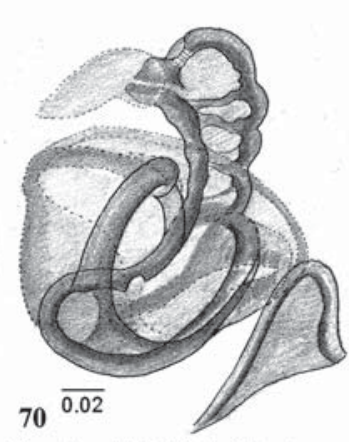

Evarcha reiskindi Palau Island

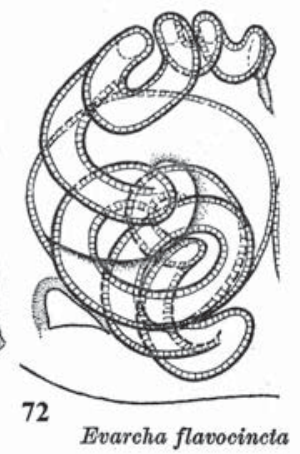

Figs 62-72. General appearance and copulatory organs of Evarcha kochi (62-69), E. flavocincta (71-72) and E. reiskindi (70): 62-63 - general appearance, dorsal and lateral views; 64-67 — palps, ventral and lateral views (note width of apophysis); 68, 71 — epigyne; 69-70, 72 - internal structures of epigyne. 62-65, 68-69 - from Lombok: Kute; 66-67 — from Lombok: Sapit; 70 — from Palau Isl.; 71-72 — from Vietnam. 70 — after Berry et al. [1996]; 68-69 — after Prószyński [1984b], 71-72 — after Żabka [1985].

Рис. 62-72. Общий вид и копулятивные органы Evarcha kochi (62-69), E. flavocincta (71-72) и E reiskindi (70): 62-63 - общий вид, сверху и сбоку; 64-67 - пальпы, снизу и сбоку; 68, 71 - эпигина; 69-70, 72 - вульва. 62-65, 68-69-с о. Ломбок: Ките; 66-67 — с о. Ломбок: Sapit; 70 — с о-вов Палау; 71-72 — из Вьетнама. 70 — по Berry et al. [1996]; 68-69 — по Prószyński [1984b], 71-72 — по Żabka [1985].

being reduced to almost vertical posterior slope. Eye field flat, rhomboidal, broadest at eyes III, with rough surface, thoracic part almost vertical. Abdomen oval and short, about as long as carapace, with dorsal surface covered by dark scutum. Legs I are striking enlarged, with long and broad femur, patella and ovoid tibia, contrasting with thin and long metatarsus and tarsus. Width of tibia additionally increased by a row of long and dense, black setae. Palp available s nearest to the holotype of $H$. malaccensis Simon, 1885, as shown by Prószyński [1987, 2010 online], with slightly smaller bulbus, almost round, except anterior $1 / 8^{\text {th }}$, which is flattened almost transversally (Fig. 75). Pictures of other species, available in the literature, show somewhat different shapes and proportions of bulbus. Tibial apophysis is as long as bulbus, relatively narrow along its whole length and gently bent upwards, without basal broadening or ventral swelling (Fig. 76).

Female. Shape and proportions of epigyne (Fig. 77) are close to the type specimen of $H$. malaccensis as shown by Prószyński [1987], except that anterior end of median pocket is not swollen and dilated (which we assume could be an individual developmental modifi- cation). Internal structures of epigyne are complicated and difficult to interpret (Fig. 78). The general plan of the main sclerotized part corresponds with that shown for the Sumatran specimen by Logunov [2000, f. 185, 187], but differs by the initial, membranous part of the copulatory duct, which, after leaving the sclerotized chamber at the entrance, encircles anteriorly the whole knot of structures, before joining the sclerotized part of the duct, postero-laterally to the spermatheca. The sclerotized duct then forms a broad, flattened loop, before joining the spherical, apparently two-chambered spermatheca. Distal part of spermatheca is very prominent: narrow, thick walled and almost as long as the oval groove on the surface. There are no " $C$ " shaped sections of the sclerotized copulatory duct, which seems to be an important difference to the related genera Bianor Peckham \& Peckham, 1885 and Sibianor Logunov, 2001.

REMARK. The type species of the genus Harmochirus Simon, 1885, with its very characteristic appearance (Figs 73-74), was illustrated first by Simon [1903]. The genital organs of males and females were first illustrated by Prószyński [1987] from the type of 

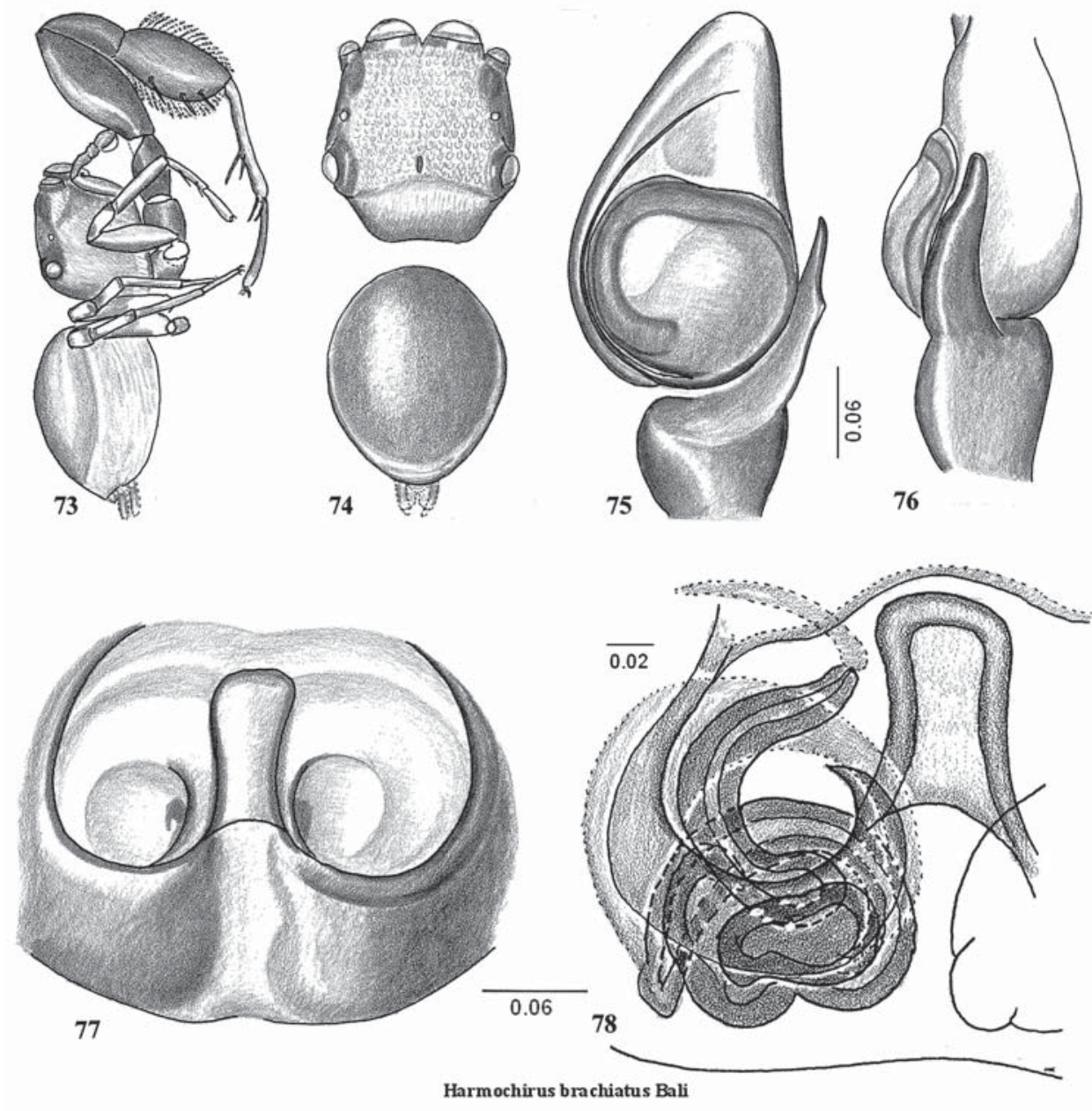

Figs 73-78. General appearance and copulatory organs of Harmochirus brachiatus from Bali: 73-74 — lateral and dorsal views, 7576 - palpus, ventral and lateral views; 77-78 - epigyne and its internal structures.

Рис. 73-78. Общий вид и копулятивные органы Harmochirus brachiatus с о. Бали: 73-74 - сбоку и сверху , 75-76 — пальпа, снизу и сбоку; 77-78 - эпигина и внутренние структуры.

H. malaccensis, from Malacca, considered by Simon [1903] to be a synonym of H. brachiatus, and H. nervosus. But are they really synonymous? Simon's synonymy cannot be accepted without some caution, and there are no comparable drawings of the type of $H$. brachiatus, described from Celebes. Available diagnostic drawings of genital organs of Harmochirus brachiatus show considerable differences, not always explicable by drawing technique and/or style used by particular authors [see survey of drawings in Prószyński, 2010 online]. There are no drawings of both general appearance and genital organs of the same specimen. Thus, the first information for eventual revision is provided here (Figs 73-78). The present identification is tentative, pending further comparative studies. Harmochirus is closely related to Bianor based on the internal structure of the epigyne, and also presumably to Havaika Prószyński, 2002.

DISTRIBUTION. Documented from Indonesia: Lombok; said to occur in the vast area from Australia to India and China (if all populations are really conspecific).

Hasarius adansoni (Audouin, 1826)

Figs 79-84.

Attus adansoni Audouin, 1826: 404, t. 7, f. 8 ( $\left.\bigcirc^{7}+\right)$.

Attus forskaeli Walckenaer, 1837: 428(+).

Attus capito Lucas, 1838: 27, t. 7, f. 8. ()

Salticus oraniensis Lucas, 1846: 144, t. 5, f. $8\left(0^{7}\right)$.

Salticus striatus Lucas, 1853: 521 (9).

Salticus ruficapillus Doleschall, 1859: 13.

Attus nigro-fuscus Vinson, 1863: 59, 302, t. 10, f. 8 (†).

Salticus citus Pickard-Cambridge O. 1863: 8561.

Plexippa nigrofusca: in Simon, 1864: 326.

Eris niveipalpis Gerstacker, 1873: $477\left(\sigma^{7}\right)$.

Salticus scabellatus Butler, 1876: 441 ().

Plexippus ardelio Thorell, 1877: $603\left(\sigma^{7}\right)$.

Euophrys nigriceps Taczanowski, 1878: 288 ( $\left.\sigma^{\top}+\right)$.

Hasarius garetti Keyserling, 1881: 1289, t. 110, f. 4 ()

Ergane signata: Keyserling, 1890: 263, t. 24, f. 5-6 (○'+).

Cyrba picturata Lendl, 1898: 561 (702-704?), f. 8 ()).

Cyrene fusca Pickard-Cambridge F., 1901: 238, t. 20, f. 6. 

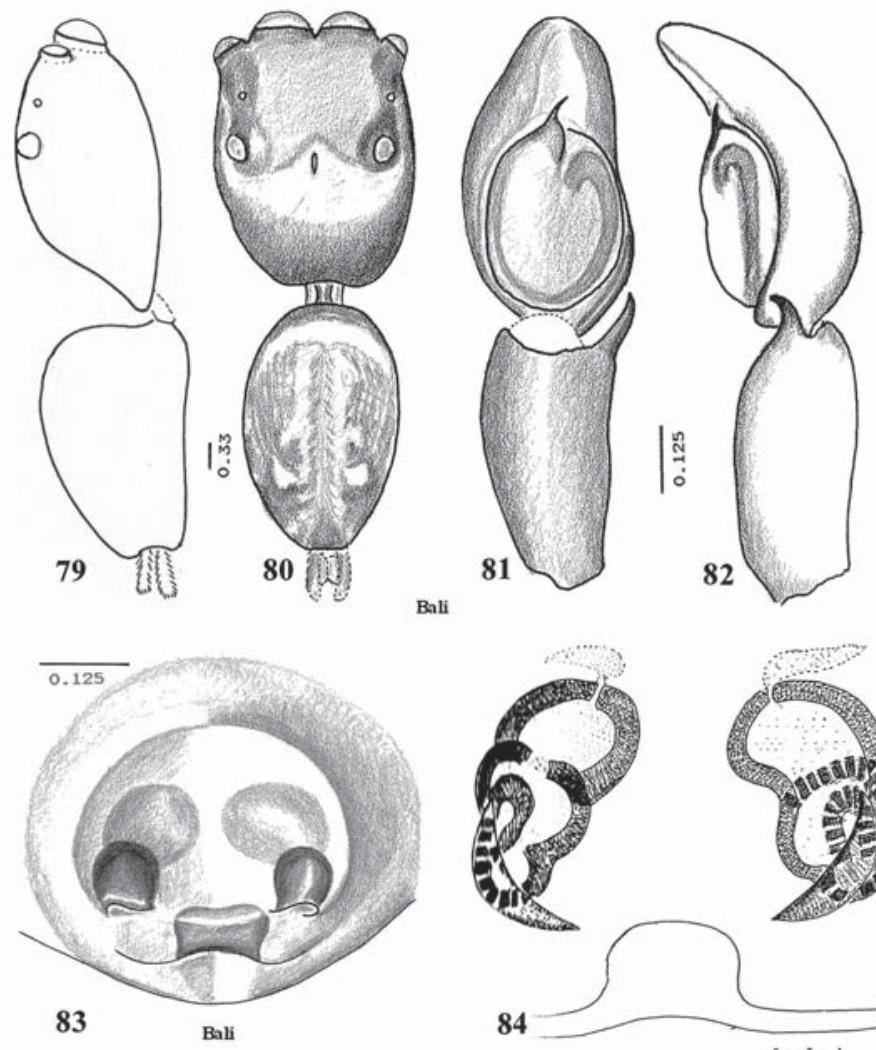

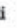

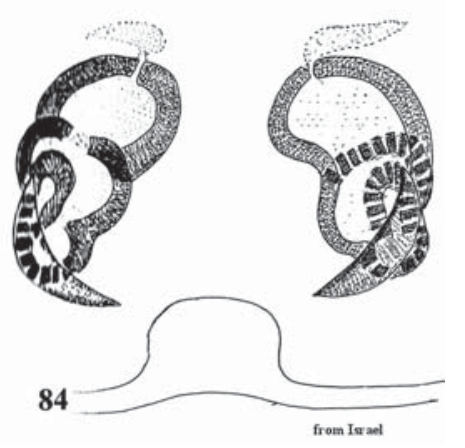

Figs 79-84. General appearance and copulatory organs of Hasarius adansoni: 79-80 - general appearance, dorsal and lateral views; 81-82 - palpus, ventral and lateral views; 83 - epigyne, note translucent spermathecae which are variably visible; 84 - internal structures of epigyne. 79-83 - from Bali; 84 - from Israel. 84 - after Prószyński [2003].

Рис. 79-84. Общий вид и копулятивные органы Hasarius adansoni: 79-80 - общий вид, сверху и сбоку; 81-82 — пальпа, снизу и сбоку; 83 - эпигина; 84 - internal structures эпигина. 79-83 - с о. Бали; 84 — из Израиля. 84 — по Prószyński [2003].

Sidusa borealis Banks 1904b: 116, f. $18\left(\mathrm{O}^{7}\right)$

Evarcha longipalpis Bosenberg \& Strand, 1906: 361, t. 14, f. $384\left(0^{7}+\right)$.

Tachyscarthmos anamensis Hogg, 1922: $310\left(0^{7}\right)$

Jacobia brauni Schmid, 1956: 150, f. 7-8D, F (†).

Vitia albipalpis Marples, 1957: 390, f. $2\left(\mathrm{O}^{7}\right)$.

Vitioides albipalpis: Platnick, 1989: 636 (replacement for Vitia).

For more synonyms: see Platnick [2010].

MATERIAL. 1 ๙ , 1 ㅇ, Bali: Sanur, cocos grove, 2.08.1992. Leg. S. Djojosudharmo. CDML.

DIAGNOSIS. General appearance shown in Figs 79-80, dark brown with white pattern, cheliceral, retrolateral tooth "fissidentate" (bicusp).

DESCRIPTION. Males with a long mane of white setae on elongate palpal tibia, and with characteristic palpal organ.

Epigyne is a simple sclerotized groove, circular, with translucent sclerotized surrounds of copulatory openings and median pocket (Fig. 83). Spermathecae are set perpendicularly to the epigyne and usually displaced during preparation, which results in artifact differences in drawings in the literature; their structure is shown in Fig. 84.

REMARK. The composite genus Hasarius Simon, 1871 contains 95 nominal species, of which barely 15 have any diagnostic drawing documentation available.
Only 7 can be considered congeneric with the type species $H$. adansoni. This species, distributed worldwide, was described under no less than 25 synonymous names, many of them from South and East Asia. In an attempt to prevent the publication of more misidentified "new species", we decided to include clear diagnostic drawings of specimens from Bali Island in this paper.

DISTRIBUTION. Cosmopolitan.

\section{Katya gen.n.}

Type species. Katya florescens sp.n.

ETYMOLOGY. Diminutive of the first name of the late Ekatarina M. Andreeva (=Katarzyna AndrejewaProszynska), an arachnologist remembered for her pioneering research on Central Asian spiders, also wife of the first author. Grammatical gender feminine, original pronunciation "Kat'ya".

DIAGNOSIS. Small, whitish or greenish non-Lyssomaninae jumping spiders, possibly belonging to Astieae, with eyes in 4 rows, anterior lateral eyes above and slightly behind anterior median eyes, external appearance similar to Astilodes mariae Żabka, 2009 (Żabka, 2009: 351, f. 1-10), but differing distinctly in the structure of the palpus and epigyne. 


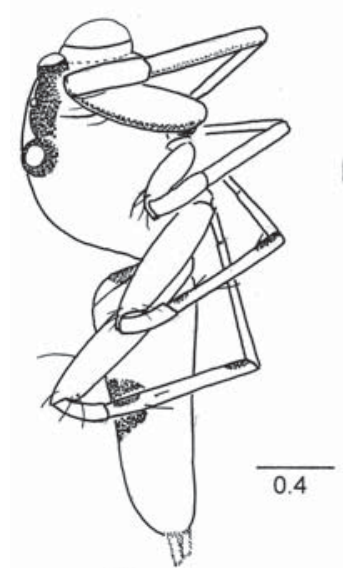

85

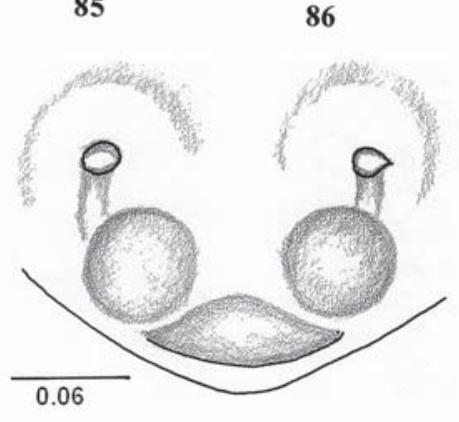

89


Figs 85-90. General appearance and copulatory organs of Katya florescens sp.n. from Flores: 85-86 - general appearance,dorsal and lateral views; 87-88 - palpus, ventral and lateral views; 89 - epigyne; 90 - internal structures of epigyne, left duct and spermatheca.

Рис. 85-90. Общий вид и копулятивные органы Katya florescens sp.n. с о. Флорес: 85-86 - общий вид, сверху и сбоку; 87-88 пальпа, снизу и сбоку; 89 - эпигина; 90 - вульва, левый семяпровод и сперматека.

DESCRIPTION. External appearance close also to Orthrus Simon, 1900, from which it differs by having much shorter and vertical chelicerae in both sexes, and by the lack of fringes of setae on legs and male palpus. Cheliceral retrolateral teeth 5-7, separate but very close to each other, all of the same length. Palpal organ and spermathecae relatively simple, resembling Orthrus, much simpler than in seemingly similar looking Asemonea O. Pickard-Cambridge, 1869. First legs slightly longer and thicker than the others, prolateral spines on tibia I and II. For more details see description of the type species, Katya florescens sp.n., below.

DISTRIBUTION. Indonesia: Flores, and Java. There are several similar species in Lombok, and Sumbawa.

\section{Katya florescens sp.n.}

Figs 85-90.

MATERIAL. $\sigma^{7}$ holotype, $\rightarrow$ allotype, $3+\circ$ paratypes, Indonesia: Lesser Sunda Islands: Flores: Moni, behind cabin, night collecting, 17.03.1992. Leg. C.L. Deeleman \& J.C. van Kempen. CDML.

ETYMOLOGY. Meaning "flowering".

DIAGNOSIS. Abdomen with a characteristic black spot, large and unusually shaped (Figs 85-86), absent in related species. Bulbus oval, embolus arises prolat- erally, short, distally hook-like (Fig. 87). Copulatory ducts in epigyne short, oblique anteriorly, thick-walled (Fig. 90), begining as a cup-like chamber with a scent opening at its postero-lateral edge. These structures cannot be compared with those of two related species, due to different methods of preparation.

DESCRIPTION. Male. Small, at present white-yellowish, strikingly black around the lateral eyes and with black spot dorsally on abdomen. There are also black spots posteriorly on chelicerae, on the underside of caput and on coxae I. Eyes in 4 rows, anterior lateral eyes behind anterior medians, their diameter two times smaller. Fringe of short hairs along edges of anterior median eyes and the black surrounds of the other eyes. There are several erect setae arising from the area between anterior lateral and posterior eyes. Carapace high, with short, sloping thoracic region. Length of carapace $1.12-1.25$, length of eyefield about 0.62 that of carapace, narrowing posteriorly, height of carapace (measured to upper part of lens of posterior eyes) is about 0.62 of length of carapace.

Palpus (Figs 87-88) with elongate cymbium, bulbus elongate oval with the duct of the sperm reservoir following smoothly the edge of the bulbus. Embolus arising from antero-prolateral angle of the bulbus, thin, 


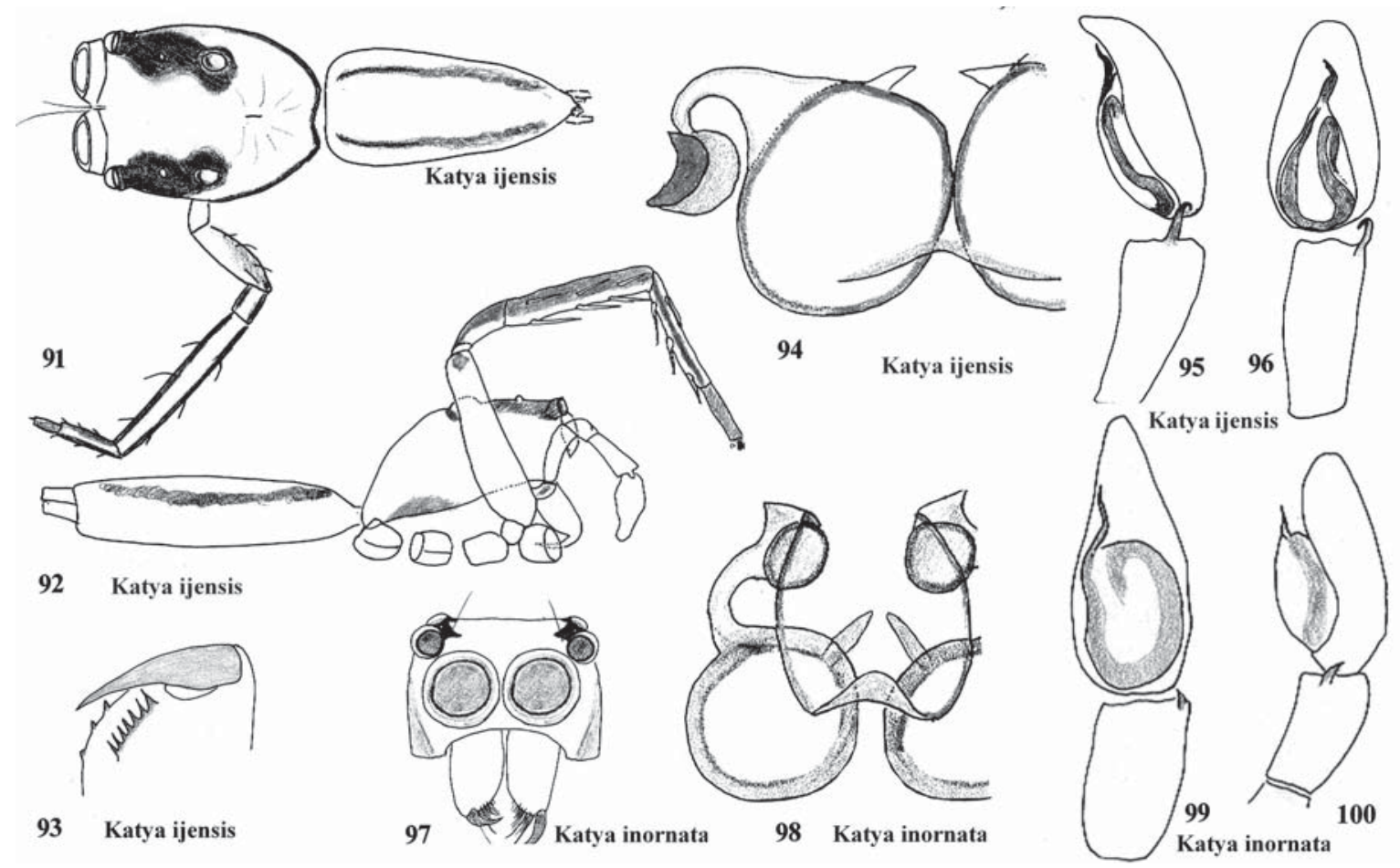

Figs 91-100. General appearance and copulatory organs of Katya ijensis sp.n. (91-96) and K. inornata sp.n. (97-100): 91-92 general appearance, dorsal and lateral views; 93 - cheliceral dentition; 97 — face; 95-96, 99-100 — palps, ventral and lateral views; 94, 98 - internal structure, left spermatheca and duct. Drawn by C.L. Deeleman-Reinhold.

Рис. 91-100. Общий вид и копулятивные органы Katya ijensis sp.n. (91-96) и K. inornata sp.n. (97-100): 91-92 - общий вид, сверху и сбоку; 93 - вооружение хелицер; 97 - «лицо»; 95-96, 99-100 — пальпа, снизу и сбоку; 94, 98 - вульва, левый семяпровод и сперматека. Рис. C.L. Deeleman-Reinhold.

but not hair-like, apically hook-like bend, its length is slightly less than $1 / 3$ of bulbus. Tibial apophysis thin and short, about equal in length to embolus, gently bent. Abdomen elongate oval, gently narrowing posteriorly, narrower than carapace, its length is 1.50 ; whitish, dorsally with a large, characteristic black spot in the middle and, occasionally, pairs of small dots.

Legs thin, of similar length, length of 5 distal segments of leg $\mathrm{I}$ is 3.3 , equal to about 3.00 of length of carapace, length of leg II 0.89 of leg I, leg III 0.93 , leg IV 1.04. Legs length order is IV, I, III, II.

Female. Externally resembling male. Posterior edge of epigyne triangular, with a pair of shallow oval grooves, in which copulatory opening are located centrally, translucent short ducts and round spermathecae, median pocket broad diamond shaped (Fig. 89). Copulatory opening followed by anterior cup shaped chamber, with minute scent opening at its postero-lateral angle, ducts sclerotized, thick walled, with narrow lumen. Spermatheca globular, thick walled, with small opening of nutritive gland located medially, just posteriorly to triangular beginning of the fertilization duct (Fig. 90).

DISTRIBUTION. Documented from Indonesia: Flores Island. Similar looking specimens of uncertain species were also found in Sumbawa $\left(2 \sigma^{\top} \sigma^{\top}, 16\right.$ +o $)$ and Lombok (6 우).

\section{Katya ijensis sp.n.}

Figs 91-96.

MATERIAL. $\sigma^{7}$ holotype, + allotype, Indonesia: E Java: Gunung Ijen, 1140 m, rainforest, 8.07.1979, Leg. P.R.\& C.L. Deeleman. Other material: 5 90,8 immatures, same data as types. CDML.

ETYMOLOGY. Named for locality Gunung (Mount) Ijen.

DIAGNOSIS. Larger than $K$. florescens sp.n., slightly larger than $K$. inornata sp.n. Distinct from the other Katya gen. n. species described here in having a pearshaped bulbus, a thicker embolus and an umbrella handle-shaped tibial apophysis. The females are distinguished by their copulatory openings situated laterally and adjacent to the spermathecae, and by their outward curved copulatory ducts. There is sexual dimorphism in the color markings of the abdomen and legs.

DESCRIPTION. Male. Shape similar to male of $K$. florescens sp.n., but larger. Erect setae on head sparse. Edge of carapace lined with dark gray in the posterior half of the carapace; abdomen with a parallel pair of pale brown bands dorsally, continued on the side up to spinnerets (Figs 91-92).

Male palp (Figs 95-96) with pear-shaped tapering bulbus, spermophore prolaterally curving mesalwards in the posterior quarter of the bulbus and abruptly narrowing. Embolus arising antero-laterally, short (section distal to the level of the bulbus tip $1 / 5^{\text {th }}$ length of 
bulbus) not apically thinning or bent. Tibial apophysis distinctive, tip in a 180 ? U-turn.

Legs less than three times as long as carapace, the fourth pair the longest. Patella, tibia and metatarsus dark brown, dorsal surface pale. In all legs, both proand retrolateral surfaces of patellae and tibiae striped with black; tip of femora dark, metatarsi and tarsi striped with brown. Cheliceral dentition consisting of 7 connate teeth in both sexes (Fig. 93).

Measurements of male (in mm). LC 1.70, LE 0.80, HC 0.87, WE1 1.00, WE3 1.12, WC3 1.25, MW 1.35, LDC 1.25, LA 2.65, MWA 1.82. Length of leg I (5 distal segments) 1.70 ,

Female. Body and legs uncolored pale yellow without any markings, except for the black eye surrounds. The epigyne was drawn from an entire specimen temporarily submerged in clove oil, the translucent internal structures are shown in Fig. 94. Median pocket situated more posteriorly than in K. inornata. Copulatory opening lateral, adjacent to spermathecae and level with anterior margin of the latter. Copulatory duct short, curved, entering spermathecae from anterior. Spermathecae globular, touching each other.

Measurements of female (in $\mathrm{mm}$ ). LC 1.57, LE 0.75, HC 0.72, WE1 0.87, WE3 1.12, WC3 1.07, MW 1.17, LDC 1.12, LA 2.42.

Length of legs ( 5 distal segments) in mm: leg I 4.3, leg II 3.7, leg III 4.0, leg IV 4.4. Length of legs order IV, I, III, II.

DISTRIBUTION. Documented from Indonesia: East Java: Mount Ijen.

\section{Katya inornata sp.n.}

Figs 97-100.

MATERIAL. $\bigcirc^{\top}$ holotype, $q$ allotype, 2 \% paratypes, Indonesia: West Java: Cibodas, Gunung Gedeh N.P., 1450 m, primary rainforest, 7-8.12.1986. Leg. S. Djojosudharmo. CDML.

ETYMOLOGY. Named after the absence of an abdominal pattern.

DIAGNOSIS. Slightly larger than $K$. florescens sp.n., distinct from the other Katya gen. n. species by the absence of markings on the abdomen and femora, and by the longer embolus: $1 / 3$ of the bulbus length, and hooked near the base. Females are distinguished by the more anterior position of the median pocket and the inwardly curved copulatory ducts (Fig. 98). Body color (in alcohol) completely white in both sexes, surrounds of eyes black, legs with dispersed black spots.

DESCRIPTION. Male. Similar to the male of $K$. florescens sp.n. and of similar dimensions. Erect setae on head fewer in number. Chelicerae with 7 connate teeth. Abdomen uncolored whitish. Male palp (Figs 99-100) with elongate, slightly tapering bulbus; spermatophora prolaterally curving mesalward halfway along the bulbus, before abruptly narrowing. Embolus arising antero-laterally, longer than in $K$. florescens sp.n. (section distal to the level of the bulbus tip is $1 / 3$ length of bulbus) and S-shaped, sharply bent at the level of anterior end of bulbus. Tibial apophysis as in $K$. florescens sp.n., short, gently curved.

Measurements of male (in mm). LC 1.62, LE 0.75, HC 0.87, WE1 0.87, WE3 0.85, MW 1.12, LDC 1.05, LA 1.75, MWA 0.67. Legs whitish, the distal part of patellae and tibiae with some dark flecks retrolaterally, metatarsi and tarsi retrolaterally striped. Length of leg ( 5 distal segments) in mm: leg I 4.8, leg II 4.6, leg III 5.0, leg IV 5.5. Length of legs order IV, III. I, II.

Female. Externally resembling the male including the appearance of chelicerae and black marks on legs. Epigyne with median pocket situated more anteriorly than in K. florescens sp.n., overlying the anterior half of spermathecae (Fig. 98). Copulatory opening followed by anterior cup-shaped chamber, Copulatory duct curved, thick-walled. Spermathecae globular, much closer to each other than in $K$. florescens sp.n., in one specimen almost touching.

Markings. Legs I with one black spot retrolaterally on the patella and distally on the tibia; leg III and IV with one black spot pro- and retrolaterally on the distal part of the tibiae. Abdomen and femora without spots. Measurements of female (in mm). LC 1.50, LE 0.72, HC 0.65, WE1 0.85, WE3 0.85, WC3 1.00, MW 1.07, LDC 1.07, LA MWA - width of abdomen at midlength (as of LC), 0.90. Length of leg I (as of LC). 3.80. Length of legs (5 distal segments) in $\mathrm{mm}$ : leg I 3.5, leg II 3.4, leg III 3.8, leg IV 3.9. Length of legs order. IV, III, I, II.

DISTRIBUTION. Documented from Indonesia: Java: Mount Gedeh National Park at Cibodas.

\section{Gen. Ligurra Simon, 1903}

Type species Ligurra latidens (Doleschal, 1859) described from Java: Tjihanjawar.

DESCRIPTION. The genus is recognizable by its body shape (Figs 101-102), setae and scales. The genus contains 3 nominal species, including a dubious one. According to Simon [1903: 842, f. 986] Ligurra differs from other genera of the Simaethae group by eyes I (anterior medians and anterior laterals) making a compact group on the facial surface, distant from the lateral edges of the face. That distance, however, is an illusion due to presenting a dorsal view of the carapace as flat in a two-dimensional drawing. In frontal view (Fig. 101) it becomes apparent that the lateral surfaces of the carapace are sloping, with the anterior lateral eyes at the top, almost touching the lateral facial edge. It is only the subocular layer, which is swollen and expanded laterally, and may have an angular shape in females (in males hidden under a bushy band of white setae). Space between the anterior median and lateral eyes is smaller than the diameter of the latter. That character may, perhaps, be diagnostic to distinguish Ligurra from other genera, where the space is broader. A broad, flattened carapace characterizes all Simaetheae, a group of genera discussed by Simon [1903: 830-844]. The tegument is hard and forms a scutum on the abdomen of males. Genital organs are 

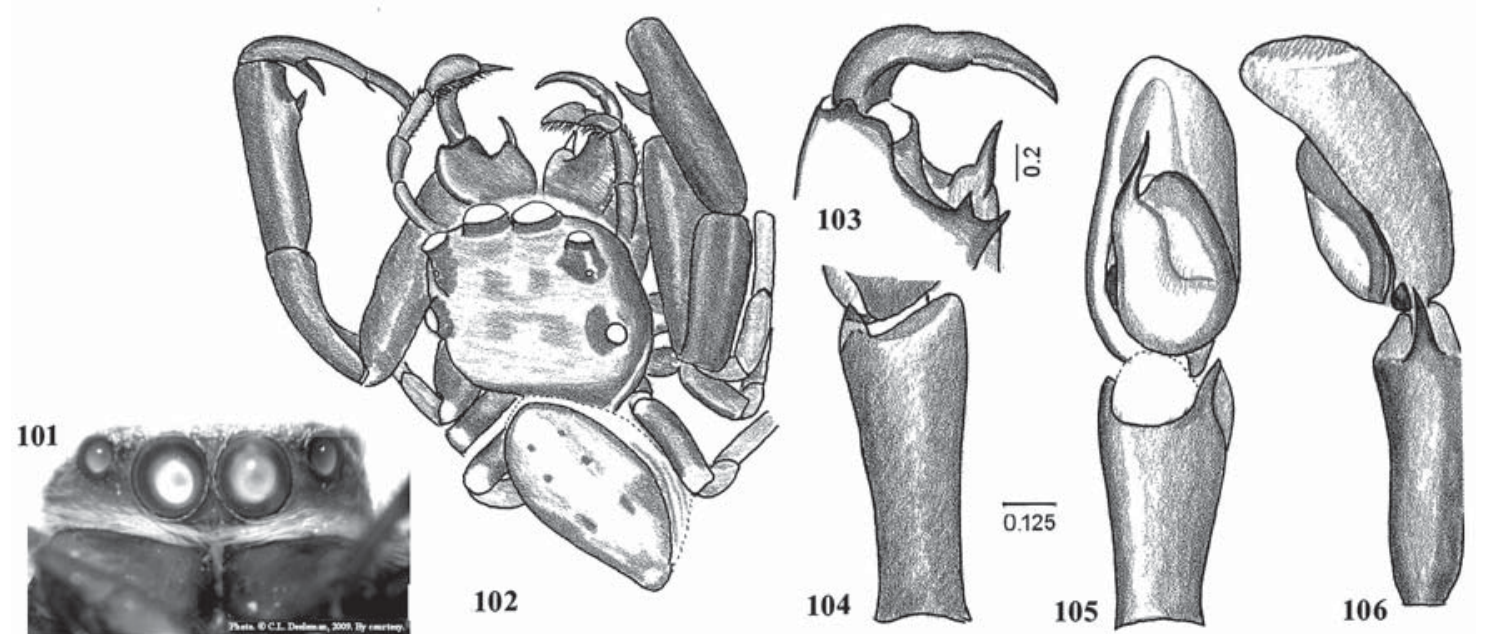

Figs 101-106. General appearance and copulatory organs of Ligurra moniensis sp.n.: 101 - face; 102 - general appearance, dorsal view; 103 - cheliceral dentition; 104 - palpal tibia, dorsal view; 105-106 - palpus, ventral and lateral views.

Рис. 101-106. Общий вид и копулятивные органы Ligurra moniensis sp.n.: 101 — «лицо»; 102 — общий вид, сверху; 103 вооружение хелицер; 104 - отросток голени, сверху; 105-106 - пальпа, снизу и сбоку.

similar, in males relatively simple palpal organs and tibial apophyses can be used to define that group of genera, but it is not yet clear to what extent they define particular genera and species. Chelicerae with retrolateral tooth forked apically (fissidentate); in related genera this tooth is often long and pillar-shaped, with fork located on top.

\section{Ligurra latidens (Doleschal, 1859)}

Salticus latidens Doleschall, 1859: 21, pl. 10, f. 6 (†). Homalattus latidens: Thorell, 1892: $262\left(\sigma^{7}\right)$.

Ligurra latidens: Simon, 1903: 842, f. 986-987 (О7).

Ligurra latidens: Prószyński, 1983: 287, f. 17-18 ( (7).

Ligurra latidens: Prószyński, 1984b: 77 (○오).

DIAGNOSIS. A striking, broad band of white setae on clypeus, and even more prom inent bands on the lateral surfaces of the carapace.

DESCRIPTION. Male. Tegument of carapace and abdomen black, covered with light reflecting scales, sometimes with a golden hue. Lateral bands of white setae broad and very striking. Patella and tibia I blackish brown, with a thin light, longitudinal line dorsally.

Female from Singapore, as shown in the photograph from Singapore by J. Koh [1989], has yellowish light brown coloration and has no prominent bands of white setae.

REMARK. The original description by Doleschall [1859] gives no details permitting the identification of the species, so the synonymies as suggested by Simon [1903: 833] are not documented; likewise, many of his identifications of specimens from various parts of the Malay Archipelago. Characters derived from the structure of the genital organs are of limited taxonomic value in these genera of jumping spiders, much more promising are photographs of live specimens, like those by J. Koh [1989: 109] from Singapore and by D. Knowles from Bali (shown in Prószyński [2010: http: / /www.gsd-salt.miiz.waw.pl/specimen.php?id=5417], but we need more photographs.

\section{Ligurra moniensis sp.n.}

Figs 101-106.

MATERIAL. $0^{7}$ holotype, "Flores, Moni, 14.08.1992. Leg. C.L. \& P.R. Deeleman". CDML.

ETYMOLOGY. Named for its collection locality: Moni on Flores Isl.

DIAGNOSIS. Very similar to the type species of the genus (see above), but differs by having a narrower band of white setae on the clypeus and lower lateral surfaces, very striking (at least on the preserved specimen), tibia I and patella I are distinctly longer. Differs from L. oppeli Berry, Beatty \& Prószyński, 1997 from the Caroline Islands by having a shorter embolus, narrower bulbus, longer pedipalpal tibia and shorter tibial apophysis.

DESCRIPTION. Male. Carapace flat and broad (Fig. 102), with anterior lateral eyes set at the edge of the face, above the broader lower sides of the carapace, distinctly separated from anterior median eyes, by spaces somewhat smaller than the diameter of the former (Fig. 101). Clypeus low, entirely covered with long white setae, directed transversally. This band of setae is narrower than in male L. latidens from Singapore, and much narrower along lateral edges of the carapace. Abdomen as long as carapace, but distinctly narrower, elongate oval, covered dorsally by dark scutum, laterally softer and lighter. Legs I appear longer than in $L$. latidens, with patella I about as long as carapace, and tibia I longer still, with a single spine anterolaterally, short and broadened, set on a small protuberance. Palpus with cymbium as long as palpal tibia (Figs 102, 104, in Fig. 105 appears optically shortened], embolus slightly longer and distinctly less inclined than in spec- 

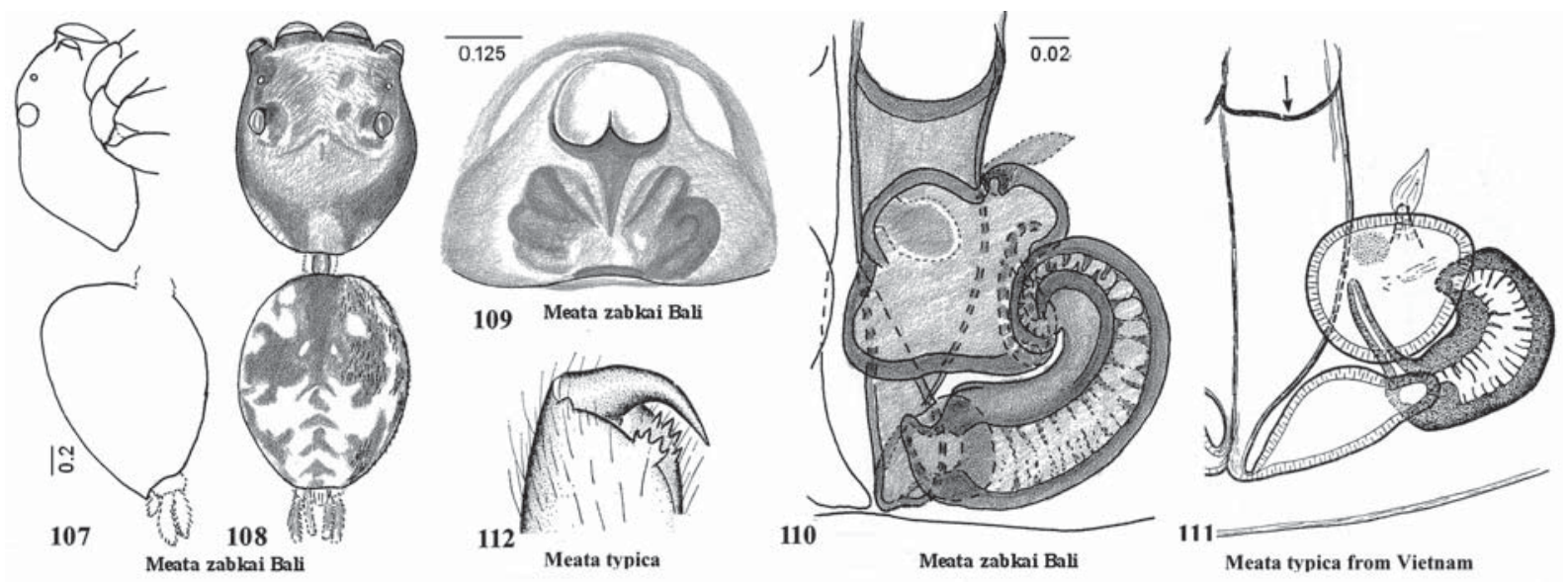

Figs 107-112. General appearance and copulatory organs of Meata Żabkai sp.n. (107-110) and M. typica (111-112, after Żabka [1985]): 107-108 — general appearance, dorsal and lateral views; 109 — epigyne; 110-111 — epigyne and its internal structures; 112 — cheliceral dentition. 107-110 - from Bali; 111-112 - from Vietnam.

Рис. 107-112. Общий вид и копулятивные органы Meata zabkai sp.n. (107-110) и M. typica (111-112, по Żabka [1985]): 107108 - общий вид, сверху и сбоку; 109 — эпигина; 110-111 - эпигина и внутренние структуры; 112 - вооружение хелицер. 107110 - с о.Бали; 111-112 - из Вьетнама.

imen of L. latidens from Sumatra [Prószyński, 1984b: 77]. Chelicerae robust and flattened, but short (Figs 102-103), their retrolateral tooth broadly forked, with slightly extended base, much shorter than in related genera; prolateral tooth long, set on broadened base, spaced from fang, the latter slightly wavying.

Female unknown.

DISTRIBUTION. Documented from Indonesia: Flores Island.

\section{Meata zabkai sp.n.}

$$
\text { Figs 107-110. }
$$

MATERIAL. + holotype, "Bali, Ambengan, from leaves, sec. forest, 20.01.1990. Leg. S. Djojosudharmo". CDML.

ETYMOLOGY. Species named after Marek Żabka, prominent arachnologist and authority on Australian, East Asian and Pacific Salticidae

DIAGNOSIS. A general jumping spider, its unique shape of the internal epigyne structures resemble the Vietnamese species Meata typica Żabka, 1985, type species of the genus Meata Zabka, 1985 (Figs 110 111), more distantly, the copulatory channels resemble those of Artabrus erythrocephalus (Figs 10-11).

DESCRIPTION. Male - unknown.

Female. Length of carapace 1.2, abdomen 1.2. General jumping spider, about $3 \mathrm{~mm}$ long, with oval abdomen, as long and as broad as carapace, eyefield rectangular, indistinctly narrowing posteriorly, occupying half the carapace length (Figs 107-108). Abdomen dark anteriorly, with lighter, irregular small spots, posteriorly light, with a posteromedial chain of 5 small chevrons and dark sides. Epigyne with a remarkable pattern of translucent internal parts. The anterior groove is a transverse oval, partially divided posteriorly (Fig. 109). Copulatory ducts are long, broad and sclerotized, touching each other along the posterior $2 / 3^{\text {rd }}$ of the epigyne, turning laterally near posterior edge of epigyne, at an angle of 45 degrees, and with the indistinct opening of the scent gland into two-chambered spermatheca. The first chamber of the spermatheca has the form of a semicircular duct, broad and heavily sclerotized, with internal wrinkles and spines. It joins the second chamber of spermatheca, approximately rectangular, with broadly rounded corners (Fig. 108). The plan of these structures is remarkably similar to that in Meata typica, as shown by Żabka [1985: 239, f. 280] (Fig. 111), except that the spermatheca is bigger and more compact, and the scent gland armature is very short and indistinct.

DISTRIBUTION. Documented from Indonesia: Bali Island: Ambengan.

Gen. Myrmarachne MacLeay, 1839

The type species is Myrmarachne melanocephala MacLeay 1839 from India.

DIAGNOSIS. Characterized by their resemblance to ants, which they mimic (Batesian mimicry). Males with enormously oversized chelicera and twisted tibial apophysis. Epigyne externally with two membranous "windows", usually oval, rarely round, with sclerotized postero-median pocket single or split, and characteristic internal structures, described below.

DESCRIPTION. 76 Oriental and Ethiopian species (out of some 200 species worldwide) from the informal tristis species group, resemble the type species of the genus. Remaining 126 species (provisionally included by Wanless into several informal species groups), resembling some other Myrmarachnine genera are rather poorly known.

Females of the tristis species group are characterized by having spermathecae in the form of sclerotized ducts of exceptionally uniform width and wall thick- 


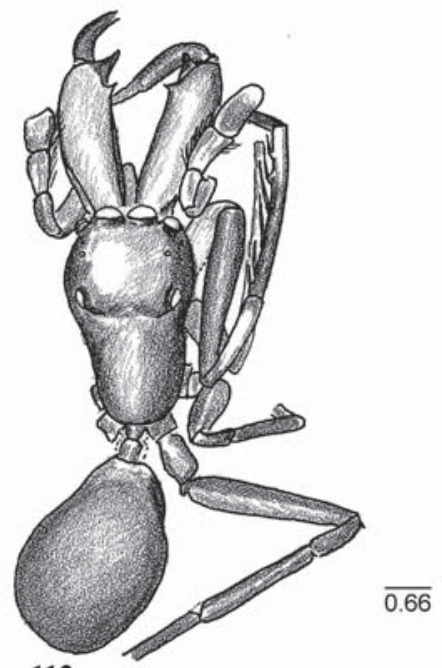

113

Myrmarachne hirsutipalpi Bal

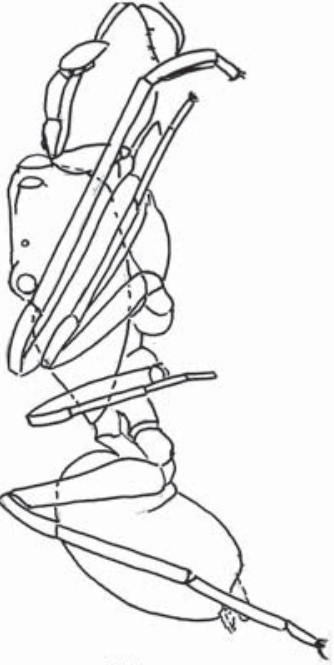

114

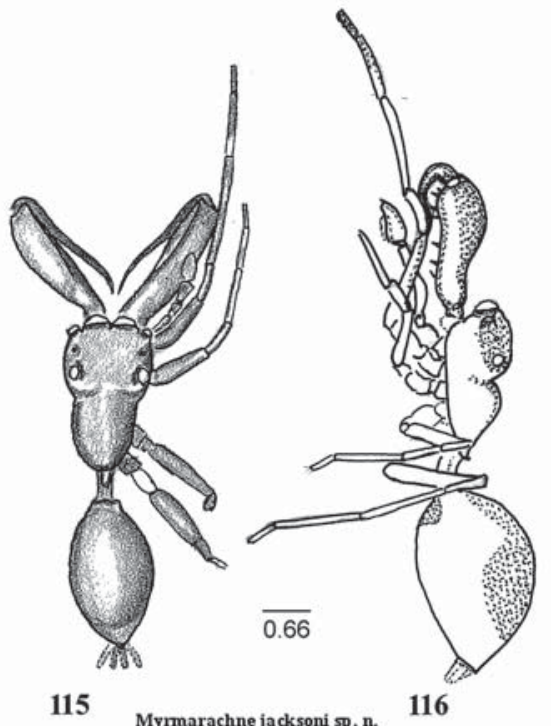

115

116

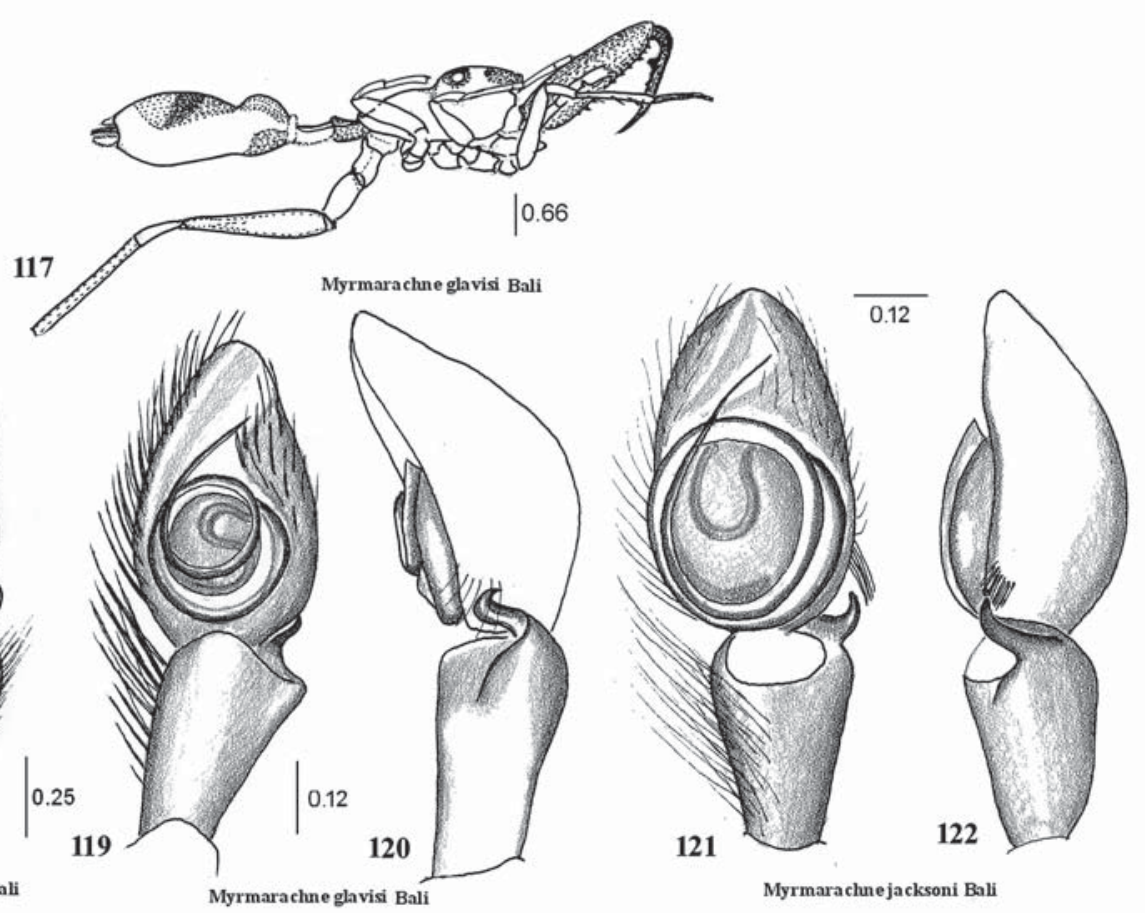

Figs 113-122. General appearance and palps of Myrmarachne hirsutipalpi (113-114, 118), M. jacksoni sp.n. (115-116, 121-122) and M. glavisi sp.n. (117, 119-120): 113-117 - general appearance, dorsal and lateral views; $118-122$ - palps, ventral and lateral views.

Рис. 113-122. Общий вид и пальпа Myrmarachne hirsutipalpi $(113-114,118)$, M. jacksoni sp.n. $(115-116,121-122)$ и M. glavisi sp.n. (117, 119-120): 113-117 — общий вид, сверху и сбоку; 118-122 - пальпы, снизу и сбоку.

ness along their whole course, parallel and touching along the second third of their length. In the anterior part of the duct there is a side detour loop, or loops twisted into double spiral, after which terminal part of spermathecae return to the previous course. The membranous copulatory ducts (transparent and visible after clearing and staining in Chlorazol Black E) form a large irregular knot (overlooked in some drawings, diagramatized, or simplified in others), which originate as a tight, almost invisible slit at the median edge of each "window", follow a complicated course and finally join the posterior end of the sclerotized spermathecal ducts. The taxonomic importance of these transparent copulatory ducts was discovered by Prószyński only in 1990ies [for first published drawings see Berry, Beatty \& Prószyński, 1996: f. 90, 96, 102] and are not noted in the earlier literature. The majority of males in the tristis group have their tibial apophysis twisted into a small hook, usually with developed flange. There is an additional loop of spermophore inside bulbus, which is small and thin, with a "gap" directed anteriorly. 
REMARK. Protective ant resemblance is developed in various families of spiders and in several subfamilies of Salticidae (for instance Dioleninae and Myrmarachninae), so it cannot be interpreted alone as indication of relationships. Better indications may be derived from the palps and internal structures of the epigyne, but these were only superficially studied in Oriental and Ethiopian "Myrmarachne". After fine studies by Peckham \& Peckham [1892], the major study was published by Wanless [1878], who proposed classification into informal groups of species, mainly Ethiopian. More detailed knowledge of the genital structures of Vietnamese Myrmarachne was provided by Żabka [1985], those from the Pacific Islands by Berry, Beatty \& Prószyński, 1996, from Malaysia by Edmunds \& Prószyński [2003] and from Taiwan by Huang [2004]. An extensive list of other relevant publications and lists of species included into particular groups are given in Prószyński [2010].

Views on classification of the genus Myrmarachne were exchanged in the personal correspondence of one of the present authors (J. Prószyński) with G.B. Edwards during several years, and contributed to the important publication by Edwards \& Benjamin [2009] (especially p. 15-19, f. 6), not signed by Prószyński [due to differences of views on synonymy of genera and species synonymised with $M$. melanocephala].

Of the groups listed by Wanless [1978], we propose now to merge the tristis and formicaria groups. Future research will probably restrict the name Myrmarachne to that group. Other groups established by Wanless could preferably be merged with other Myrmarachninae genera or described as independent genera.

DISTRIBUTION. The center of diversity of the genus Myrmarachne lies in the Ethiopian and Oriental Regions, from where they possibly migrated to the Palaearctic, Australia, Central and South America. However, the genus in the Malay Archipelago is very insufficiently known. Myrmarachne are better studied in Malaysia (including the Malay Peninsula) with 9 identifiable species (out of 12 nominal) and the Philippines [Prószyński, in preparation] - 19 species (out of 23 nominal). The fauna of Indonesia is even much less well known, with only 2 species having diagnostic drawing documentation (out of 20 nominal species). There are 10 species listed from Australia (none identifiable because of lack of diagnostic drawings), no species have been reported from New Guinea.

\section{Myrmarachne balinese sp.n.}

Figs 123-124.

MATERIAL. + holotype [with epigyne cleared, kept in a microvial], 1 q paratype, Bali: Ambengan, secondary forest, 1931.01.1990. Leg. S. Djojosudharmo." CDML.

ETYMOLOGY. Named after Bali Island.

DIAGNOSIS. White membranous "windows" in epigyne unusually small and circular, spermathecae side detour consistis of three irregular loops.
DESCRIPTION. Female. Epigyne with 2 small circular white membranous "windows" (Fig. 123), blocked by a brown secretion in the paratype specimens. Posterior pocket slightly broadened anteriorly (Figs 123124), located slightly more anteriorly than in other species, at the top of a relatively broad posterior depression. Membranous copulatory ducts begin at the medial, almost invisible slits, run along an irregular elliptical course and join the sclerotized medial ducts of spermathecae at their posterior end, near the relatively well developed armature of a scent gland. As in the majority of other Myrmarachne species, the straight and sclerotized ducts of the spermathecae run medially along the whole length of the epigyne and continue after making a side detour of a double spiral, consisting of three irregular loops. After the detour, beyond the rim of the windows, the anterior (distal) part of the spermathecae continue their previous course. That part has distinct teeth on its internal surface, and terminates at a small circular chamber, twice as broad as the spermathecal duct (Fig. 124).

DISTRIBUTION. Documented from Indonesia: Bali Island: Ambengan.

\section{Myrmarachne glavisi sp.n.} Figs 117, 119-120, 125-126.

MATERIAL. + holotype, $\sigma^{7}$ allotype, Bali: Ambengan, secondary forest, 19-31.01.1990. Leg. S. Djojosudharmo." CDML.

ETYMOLOGY. Named after Glavis B. Edwards, my friend and author of important papers on Salticidae, including one redefining the type species of the genus Myrmarachne.

DIAGNOSIS. Resembles to some extent $M$. ramosa Badcock, 1918 [see Edmunds \& Prószyński, 2003: 301, f. 8-29], from which it differs in the female by the presence of a single median pocket in the epigyne, not split into two, and by larger oval epigynal "windows". In males, the narrowing of thorax is less striking than in M. ramosa.

DESCRIPTION. Male. Body elongate, relatively low, with long petiolus and both a thoracic and an abdominal constriction (Fig. 117). Bulbus small, with an additional loop of the sperm reservoir set transversally. The tibial apophysis appears longer than in other species. It is bent in a hook-like manner apically, with a well developed flange (Figs 119-120).

Female. Epigyne with a single median pocket, relatively narrow and long, opening near posterior edge of epigyne (Fig. 125). The membranous "windows" are large, ending anteriorly with an angular ending, rounded posteriorly. The duct-like part of the spermathecae is proportionally thin and appears longer than in other species. The detour of the sclerotized copulatory ducts consist of a single loop. The anterior (distal) part of spermatheca has a few internal spines (Fig. 126).

DISTRIBUTION. Documented from Indonesia: Bali Island: Ambengan. 

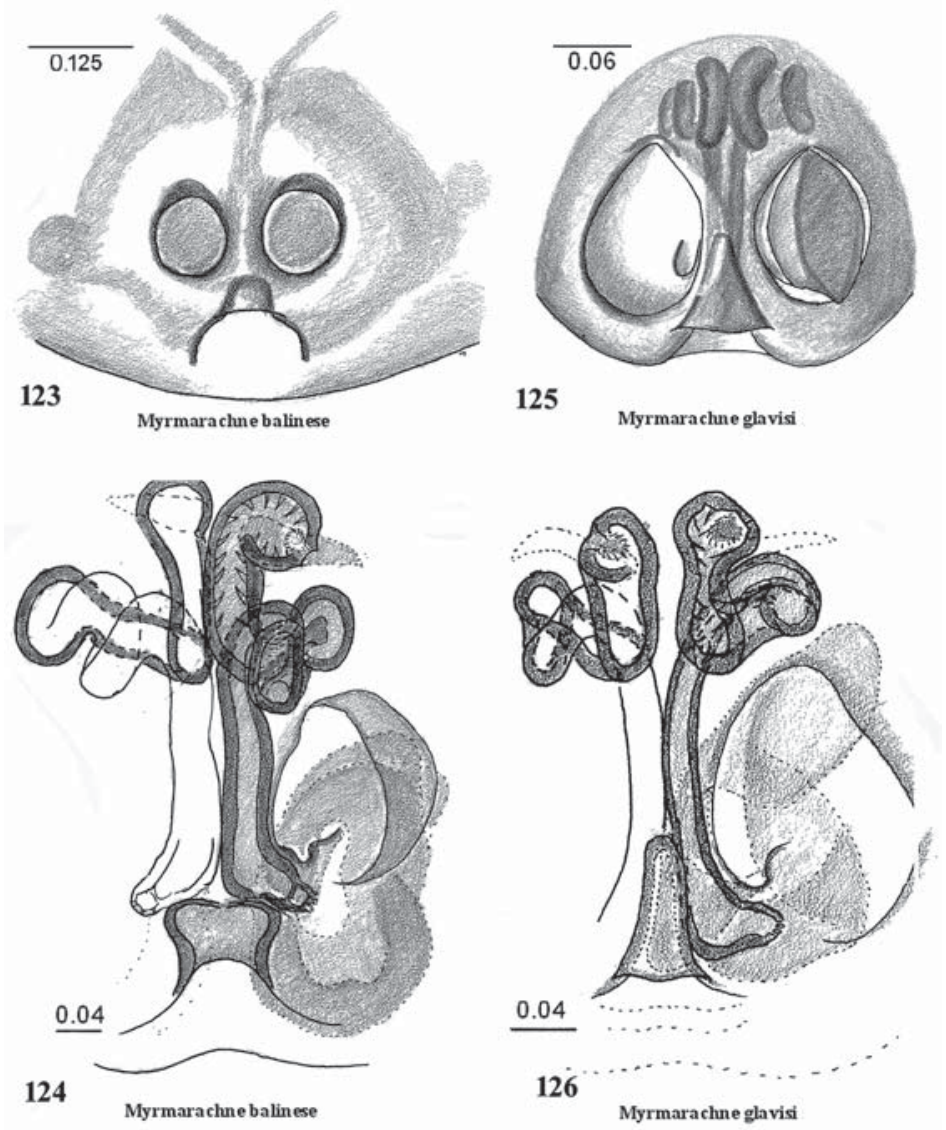

Figs 123-126. Epigyne and its internal structures of Myrmarachne balinese sp.n. (123-124) and M. glavisi sp.n. (125-126). Рис. 123-126. Эпигина и внутренние структуры Myrmarachne balinese sp.n. (123-124) и M. glavisi sp.n. (125-126).

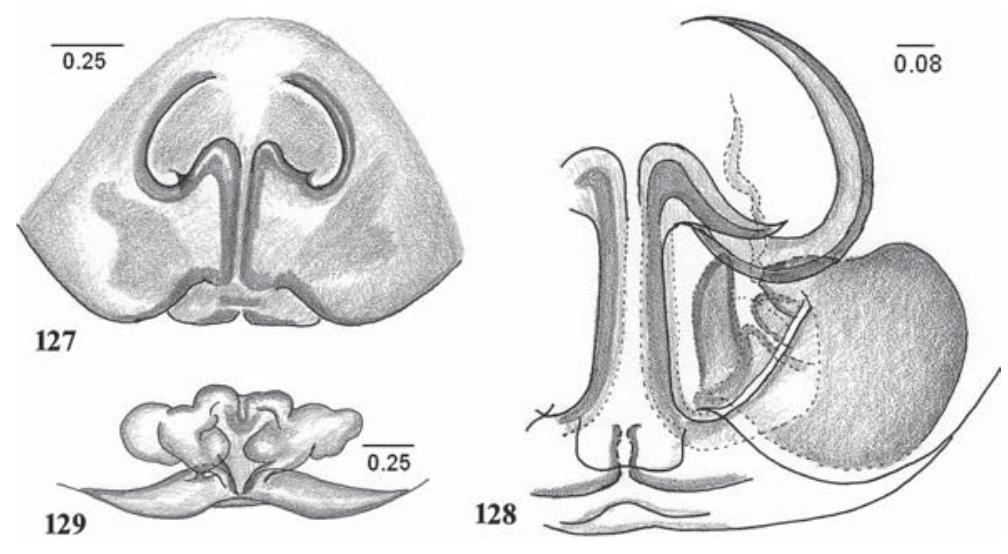

Figs 127-129. Epigyne and its internal structures of Phaeacius azarkinae sp.n., ventral and posterior views. Рис. 127-129. Эпигина и внутренние структуры Phaeacius azarkinae sp.n., снизу и сзади. 

2003

Myrmarachne hirsutipalpi Edmunds \& Prószyński, Figs 113-114, 118.

Myrmarachne hirsutipalpi Edmunds \& Prószyński, 2003: 319 321, f. $110-116\left(\sigma^{7}+\right)$.

MATERIAL. 1 " "Bali: Ambengan, secondary forest, 1931.01.1990. Leg. S. Djojosudharmo.” An additional specimen from Bali: lake Tambligan is kept in the collection. CDML.

DIAGNOSIS. Differs by prolateral mane of dense and long, dark setae on palpal tibia and cymbium. Gap in the translucent seminal duct directed towards 1 o'clock.

DESCRIPTION. Male. Anterior half of carapace broader than eyefield, narrowing and lowering in the posterior half, but without distinct thoracic constriction (Figs 113-114). Abdomen pear shaped, narrower at the junction with the petiolus, but without abdominal constriction. Chelicerae broad, about $3 / 4^{\text {th }}$ the length of the carapace, laterally blackish brown, ventrally brown, with triangular, sclerotized flap near the fang. Coxa I white, coxae II-IV brown. Palpus with prolateral mane of dense and long, dark setae on tibia. Bulbus with broad gap of sperm reservoir at 1 o'clock, without thin accessory loop (Fig. 118). Tibial apophysis bent, weavy.

Female unknown.

REMARKS. May belong to the Myrmarachne gros$s a$ group of species.

DISTRIBUTION. Documented from Indonesia: Bali Island: Ambengan, Malaysia: Genting, Singapore: Malacca.

\section{Myrmarachne jacksoni sp.n.}

Figs 115-116, 121-122.

MATERIAL. $\sigma^{7}$ holotype, Bali: Ambengan, secondary forest, 19-31.01.1990. Leg. S. Djojosudharmo.” CDML.

ETYMOLOGY. Named after Dr. Robert R. Jackson, author of a large series of papers on Salticidae behavior, including many on Myrmarachne, and also for taking excellent photographs of jumping spiders.

DIAGNOSIS. Resembles M. cornuta Badcock, 1918 in palpus shape (Figs 121-122), but differs by having a shorter body without an abdominal constriction.

DESCRIPTION. Male. Chelicerae about as long as carapace, spread widely apart in the preserved specimen. Carapace with a dorsal constriction behind the eyefield, shallower than in M. cornuta (see drawings in Edmunds \& Prószyński [2003: f. 30-39] and petiolus distinctly shorter. Abdomen relatively short, ovoid, without constriction (Figs 115-116). Palpal organ with cymbium longer and broader than the tibia, bulbus larger than in males of the two species described above. Additional loop of sperm reservoir about half the length of the bulbus, arranged longitudinally, with gap orientated towards 12 o'clock (Figs 121-122). Tip of tibial apophysis gently bent, but not twisted or hook-like. There is a row of stout but short bristles on the retrolateral surface of the cymbium, corresponding to the apophysis' tip.

Female unknown.
REMARKS. May belong to the tristis group. The specimen studied is preserved with chelicerae broadly spread. R.R. Jackson comments: "Myrmarachne makes dramatic use of its ability to move chelicerae far apart. Sometimes during male-male displaying, the chelicerae are moved out about perpendicular to the body"s axis. It is an extraordinary thing to see. Ability to move chelicerae so dramatically apart does seem to be something special about the males of this genus" (Jackson, personal letter).

DISTRIBUTION. Documented from Indonesia: Bali Island: Ambengan.

\section{Phaeacius azarkinae sp.n.}

Figs 127-128.

MATERIAL. $q$ holotype, Sumbawa: Samokat, S of Sumbawa Besar, secondary forest, 1-3.01.1990. Leg. S. Djojosudharmo. CDML.

ETYMOLOGY. Named after Galina Azarkina, a prominent arachnologist from Novosibirsk (Russia), specializing in Aelurillinae.

DIAGNOSIS. The epigyne is unique in having an anterior groove located anteriorly, and it is distinctly smaller than the nearest other species, $P$. canalis Wanless, 1981 [Wanless, 1981: f. 8A-G] from the Philippines. Females of all remaining species have the groove divided into two.

DESCRIPTION. Female. A relatively large jumping spider, body approximately $10 \mathrm{~mm}$ long, appearance similar to that of other species of the genus. Epigyne with a single groove (Fig. 127), resulting from the incomplete division of two separate grooves, as in other species. Its length is approximately equal to half the length of the epigyne (as measured from the anterior rim to the copulatory openings). The same is distinctly longer in $P$. canalis Wanless, 1981, P. leytensis Wijesinghe, 1991, P. saxicola Wanless, 1981 and $P$. wanlessi Wijesinghe, 1981. There are two separate grooves in P. fimbriatus Simon, 1900 and $P$. malayensis Wanless, 1981 [Prószyński, 2010 online]. Sclerotized, semicrescent rims of the groove are developed posteriorly and laterally, but are not distinct anteriorly. Copulatory openings are located at the posterior median end of the groove, the copulatory ducts run straight posteriorly, at end of epigyne turning laterally and joining large, semispherical spermatheca (Fig. 128). A posterior view of spermathecae preparation is shown in Fig. 129.

Dimensions. Length of carapace $4.95 \mathrm{~mm}$, proportions LE 0.43, HC 0.51, WE1 0.57, WE3 0.51, WC3 0.76 , MWC 0.78, LA 1.19, MWA 0.70, leg I as ratios to length of LC) 2.30. Length of legs (5 distal segments, in $\mathrm{mm}$ and as ratios to length of leg I): leg I $11.40=1.00$, leg II $12.20=10.07$, leg III $12.20=1.07$, leg IV $13.90=1.22$. Length of legs order: IV, III=II, I.

REMARK. Epigyne comparable to that of $P$. fimbriatus Simon, 1900, the type species of the genus, and to 6 other species for which epigyne reference documentation exists [Prószyński, 2010].

DISTRIBUTION. Documented from Indonesia: Sumbawa Island. 


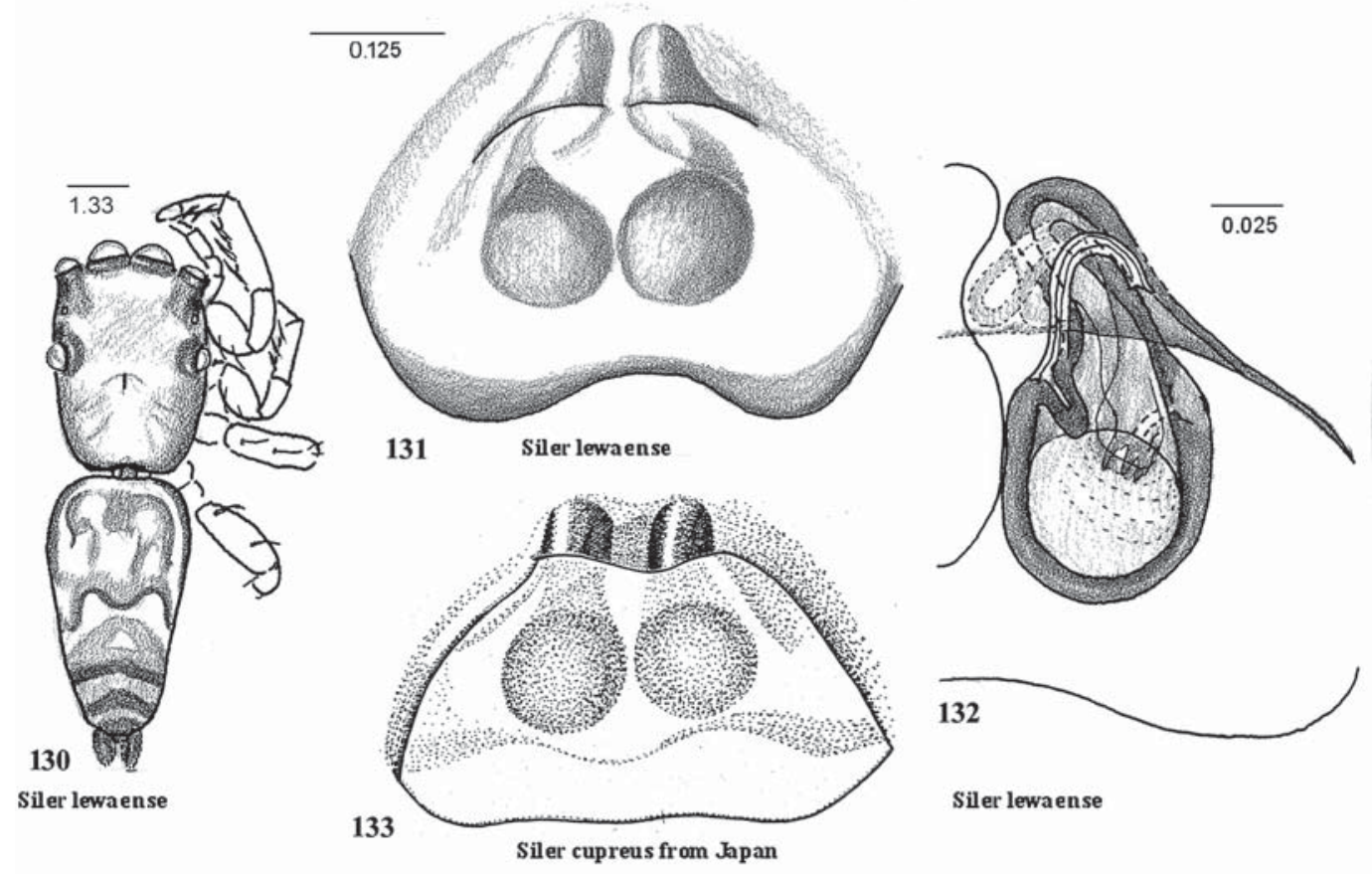

Figs 130-133. General appearance and epigyne of Siler lewaense sp.n. (130-132) and Siler cupreus (133): 130 - general appearance; 131-133 - epigyne and its internal structures. 130-132 - from Sumba; 133 - from Yokohama. 133 - after Prószyński [1984b].

Рис. 130-133. Общий вид и эпигина Siler lewaense sp.n. (130-132) и Siler cupreus (133): 130 — общий вид; 131-133 — эпигина и внутренние структуры. 130-132 — с о. Сумба; 133 - из Йокогамы. 133 - по Prószyński [1984b].

\section{Siler lewaense sp.n.}

Figs 130-132.

MATERIAL. + holotype, Sumba: primary forest W of Lewa evergreen forest, $35 \mathrm{~km} \mathrm{W.} \mathrm{of} \mathrm{Waingapu,} \mathrm{11.08.1992.} \mathrm{Leg.} \mathrm{C.L.}$ Deeleman. CDML.

COMPARATIVE SPECIMEN: Paralectotype "3670. Siler cupreus ES. Yokohama”. MNHM.

ETYMOLOGY. Named after its collection locality - Lewa, on Sumba Isl.

DIAGNOSIS. Epigyne similar to that of the type species of the genus S. cupreus (Simon, 1889) (Fig. 133) from Japan: Yokohama, from which it differs in structural proportions. The color pattern is distinctive.

DESCRIPTION. Female. Body covered with iridescent scales. Abdominal pattern consists of silver spots on an orange background, accentuated by thick black bands, the latter separated by metallic blue in the posterior region of the abdomen (Fig. 130). Epigyne (Fig. 131) in the form of a transverse oval groove, with its posterior rim bent, anteriorly with two sclerotized hood-like pockets, hiding broad copulatory openings. Copulatory duct broad and sclerotized, originally running forwards, then changing direction by 180 degrees and, still broadening, joining spherical spermatheca. There is membranous loop near the bend of the duct, never observed in any other female Salticidae. There is also a thin and long membranous duct arising from spermatheca medially, near junction of the duct; perhaps this is the armature of the scent gland opening, ending under the anterior hood. Lateral wall of each spermatheca has a funnel-like depression, with a short channel directed inside the spermatheca, surrounded by concentric striations, apparently a nutritive gland opening (Fig. 132).

Length of Carapace $1.62 \mathrm{~mm}$, proportions LE 0.50, HC 0.46, WE1 0.73, WE3 0.77, WC3 0.77, MWC 0.77, MWA 0.62, leg I (as ratios to LC) 2.11. Length of legs ( 5 distal segments, in $\mathrm{mm}$ and as ratios to length of leg I): leg I $3.42=1.00$, leg II $2.80=0.82$, leg III $2.80=0.82$, leg IV $3.67=1.07$. Length of legs order IV, I, III=II.

REMARK. Siler Simon, 1889 is one of several brightly colored Oriental genera, with its body covered by iridescent scales. Carapace often covered with green or red scales, also with bands, lines and spots of other contrasting colors. In some species the anterior $2 / 3^{\text {rds }}$ of abdomen is red, with pair (or two pairs) of contrasting oval spots, white, blue, or silver. The posterior $1 / 3^{\text {rd }}$ of the abdomen is black with white lines. Male tibia I with long black setae [see photos by D. Knowles, reproduced in Prószyński, 2010 online]. Because of its vivid coloration, it could be mistaken for the tropical genus Cosmophasis Simon, 1902, and presumably other genera. The delimitation of color pattern characters has not yet been studied in full, but the abdominal pattern of Cosmophasis sp. usually includes a median line instead of pairs of oval spots.

DISTRIBUTION. Documented from Indonesia: Sumba Island. 
Spartaeus spinimanus (Thorell, 1878)

Figs 134-137.

Boethus spinimanus Thorell, 1878: 221 (imm.)

Nealces caligatus Simon, 1900: 30 (+).

Nealces striatipes Simon, 1900: $30\left(\mathrm{O}^{7}\right)$.

Boethus striatipes Simon, 1901: 401, f. 413-415 (o

Boethus caligatus Simon, 1901: 401, f. 419-420.

Boethus gracilis Reimoser, 1925: 90 (+).

Spartaeus spinimanus: Wanless, 1984: 148, f. 3A-F, 4A-G, 30A-D, 33F, 35A ( $\left(\sigma^{\top}+\right)$.

MATERIAL. O',Sumbawa: Samokat, S. of Sumbawa Besar, secondary forest, 1-3.01.1990. Leg. Suharto Djojosudharmo. Det. J. Prószyński. CDML.

DIAGNOSIS. Recognizable by details of the shape of the palpus, especially the tibial apophysis (Figs 134 137).

DESCRIPTION. See Wanless [1984].

REMARK. Type species of the genus. The drawings presented here give additional details to the description by Wanless [1984: 148, f. 3a-f, 4a-b]. The palpus is shown in larger scale - note the presence of a dense mane of white setae on the anterior half of the cymbium dorsally (Fig. 134), the process and the filament near the base of the embolus, and details of both rami of the tibial apophysis (Figs 135-137).

DISTRIBUTION. Documented here from Indonesia: Sumbawa Island, originally described from Ambon Island, reported also from Java, Sumatra, Borneo: Sarawak, Singapore and Sri Lanka.

\section{Stergusa incerta $\mathbf{s p . n .}$}

Figs 138-141.

MATERIAL. $\sigma^{r}$ holotype, Sumbawa Besar, $480 \mathrm{~m}$ a s, sec. forest, 3.01.1990. Leg. S. Djojosudharmo. CDML.
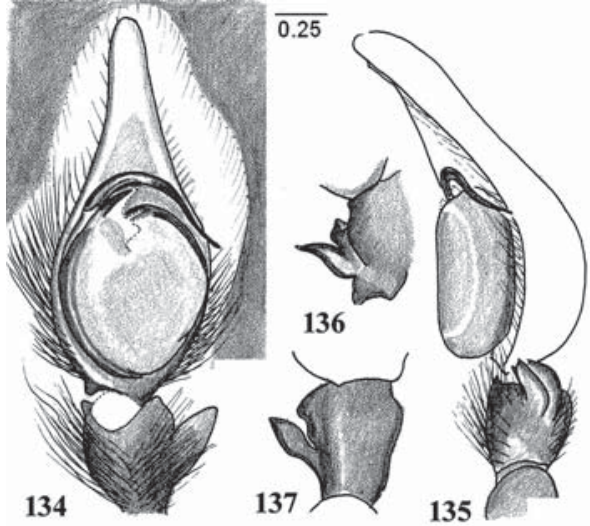

Figs 134-137. Palpus of Spartaeus spinimanus: 134-135 palpus, ventral and lateral views, 136-137 — palpal tibia, dorsolateral and dorsal views.

Рис. 134-137. Пальпа Spartaeus spinimanus: 134-135 пальпа, снизу и сбоку, 136-137 — голень пальпы, сверхусбоку и сверху.

ETYMOLOGY. Name meaning "uncertain".

DIAGNOSIS. Small species with long and low carapace, eyefield stretching over most of the flat surface, the posterior slope steep.

DESCRIPTION. Male. Small specimen, at present deteriorated, with long and low carapace, eyefield stretching over most of the flat surface, the posterior slope steep (Fig. 138). Anterior median eyes large, occupying whole height of face, anterior lateral eyes aligned along dorsal edge of anterior median eyes, their diameter two times smaller. Abdomen covered
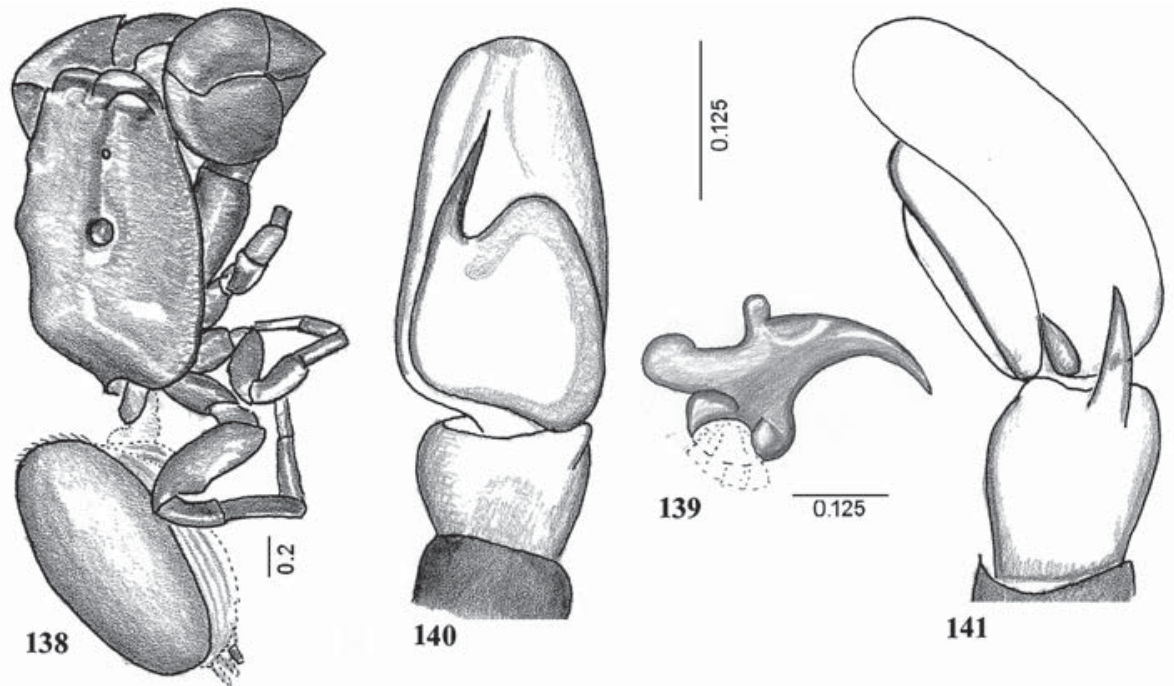

140

141

Figs 138-141. General appearance, fang and palpus of Stergusa incerta sp.n.: 138 - general appearance, dorso-lateral view; 139 fang, ventral view, note lateral swellings; $140-141$ — palpus, ventral and lateral views.

Рис. 138-141. Общий вид, коготок хелицер и пальпа Stergusa incerta sp.n.: 138 — общий вид, сверху-сбоку; 139 - коготок хелицеры, снизу; 140-141 - пальпа, снизу и сбоку. 

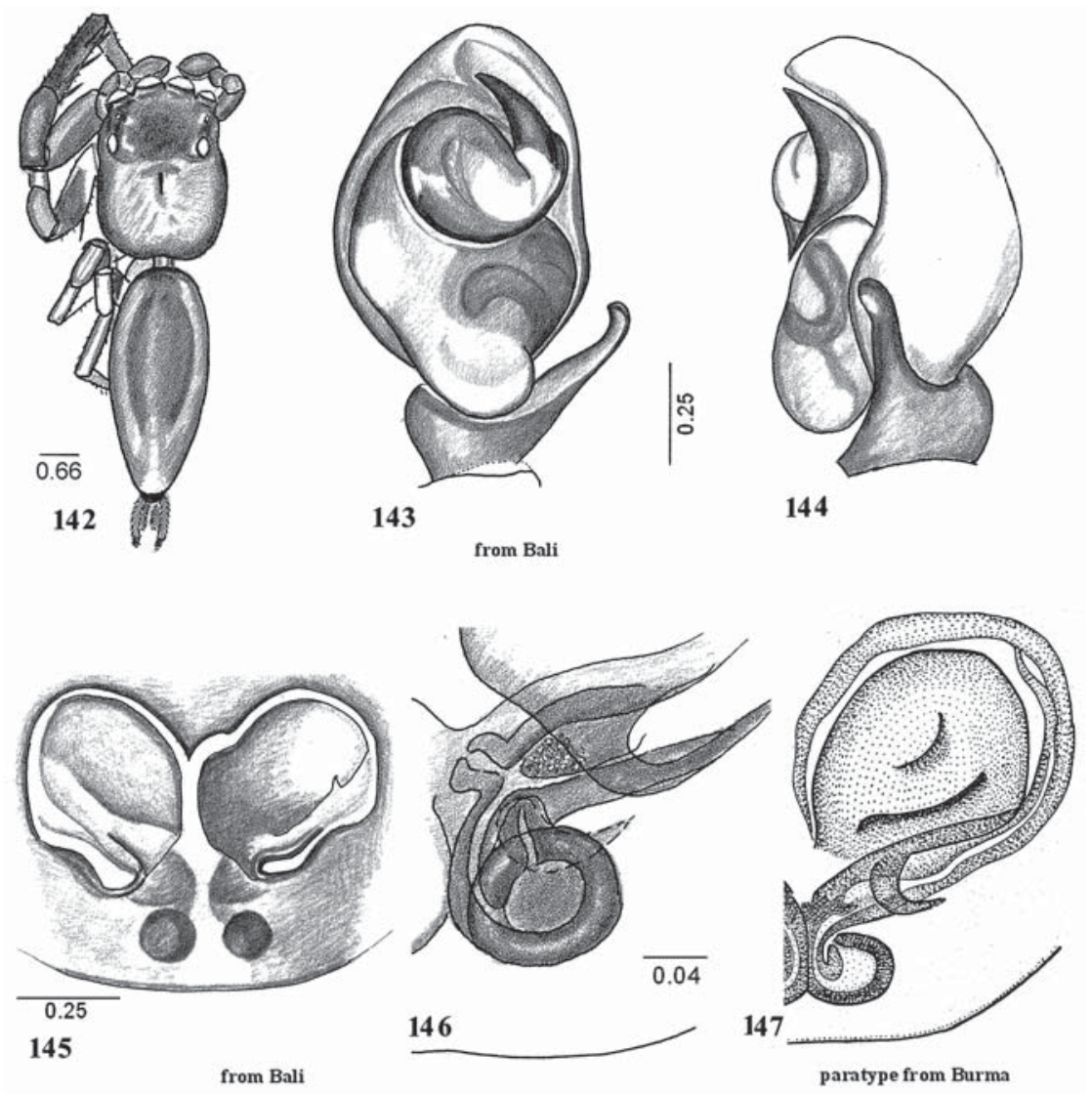

Figs 142-147. General appearance and copulatory organs of Thiania bhamoensis: 142 — general appearance, dorsal view; 143-144 — palpal organ, ventral and lateral views; 145-147 — epigyne and its internal structures. 142-146 — from Bali; 147 - from Myanmar, paratype. 147 - after Prószyński [1984b].

Рис. 142-147. Общий вид и копулятивные органы Thiania bhamoensis: 142 — общий вид, сверху; $143-144$ - пальпа, снизу и сбоку; 145-147 - эпигина и внутренние структуры. 142-146 - с о. Бали; 147 — из Бирмы, паратип. 147 - по Prószyński [1984b].

with a prominent scutum, oval, about as long as the flat part of the carapace. Leg I strikingly robust, with a very broad femur, patella and tibia, contrasting with a gradually tapering metatarsus and tarsus. Legs II-IV slender.

Palpus of rather general shape and proportions (Fig. 140), with cymbium longer than palpal tibia, bulbus simple, embolus arising antero-laterally, narrow and almost straight, indistinctly shorter than bulbus. Tibial apophysis narrow and pointed, slightly shorter than tibia, articulating with a flap on the postero-ventral angle of the cymbium (Fig. 141). Fang of chelicerae special - short, gently bent, with broad base and three protuberances (Fig. 139).

Female unknown.

REMARK. The classification of this species into the poorly known genus Stergusa Simon, 1889 is tentative; it may represent a new genus. The genus Stergusa is defined by the type species $S$. improbula Simon, 1889 from New Caledonia, and also contains 3 species from Sri Lanka, none with any pictorial documentation.

DISTRIBUTION. Documented from Indonesia: Sumbawa Island.
Telamonia jolensis (Simon, 1902) comb.n.

Figs 172-173.

Artabrus jolensis. Simon, 1902a: $404\left(O^{7}\right)$.

Artabrus jolensis: Prószyński, 1987: 3, f. (O $0^{7}$.

MATERIAL. O" type [?] — "16453 Art.[abrus] jolensis E. S. Jolo" - MNHN.

ETYMOLOGY. Named after Jolo Island.

REMARK. Described originally as Artabrus jolensis Simon, 1902 from the Philippines: Jolo Island. Its palpus (Figs 172-173) is entirely different from the type species of that genus Artabrus erythrocephalus (C.L. Koch, 1846) (Figs 3-7) but is very similar to that of Telamonia festiva Thorell, 1887, the type species of that genus. As for somatic characters in the original description by Simon [1902a], he generally misinterpeted Telamonia and his views were corrected by Prószyński [1984a: 418, f. 1-49].

Thiania bhamoensis Thorell, 1887

Figs 142-147.

Thiania bhamoensis Thorell, 1887: 357 ( $\bigcirc^{\top}$ ㅇ). Marptusa oppressa Thorell, 1892: 300, 474 ( $\left.\sigma^{7}+\right)$. 

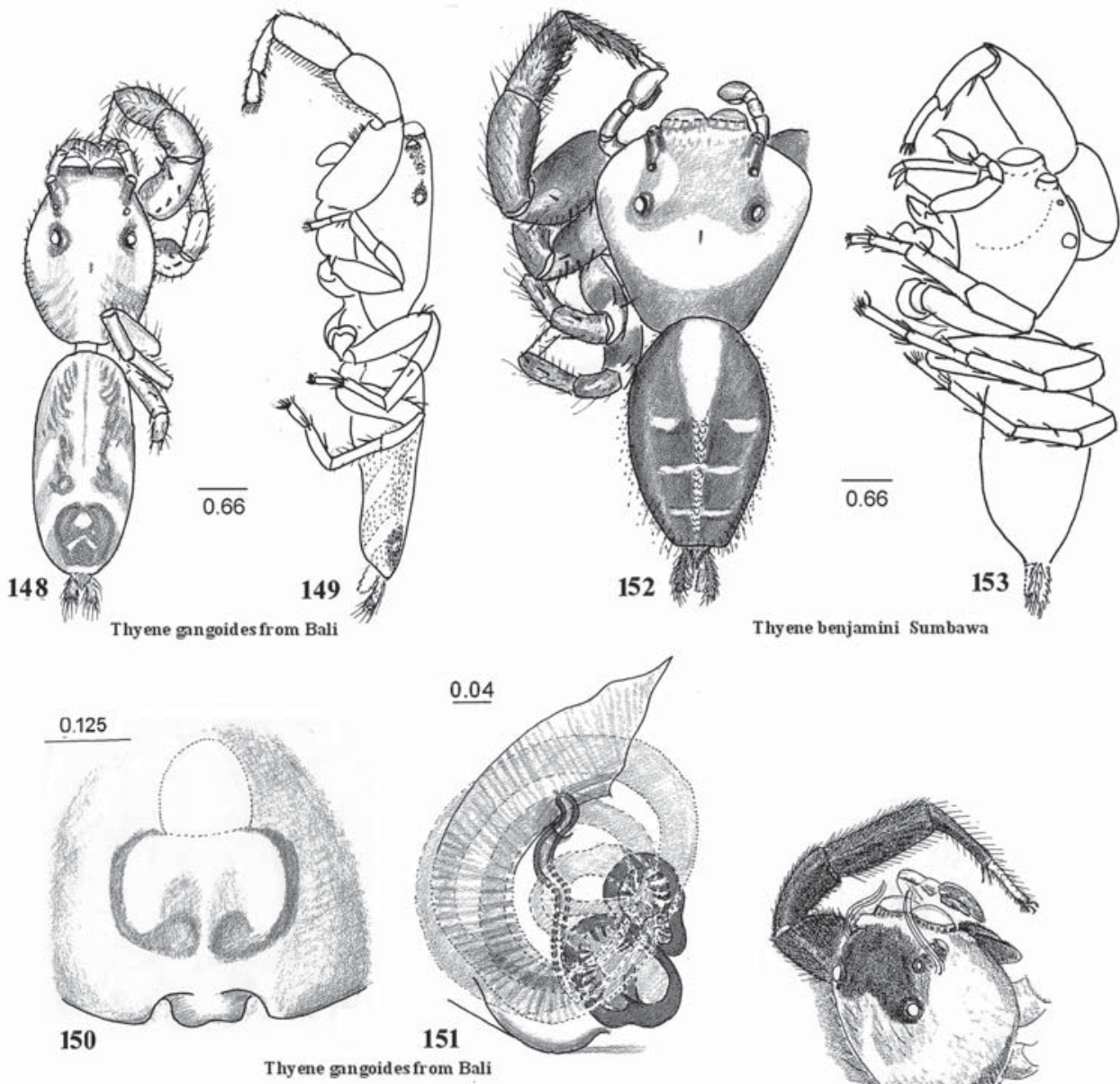

Thyene benjamini Sumbawa
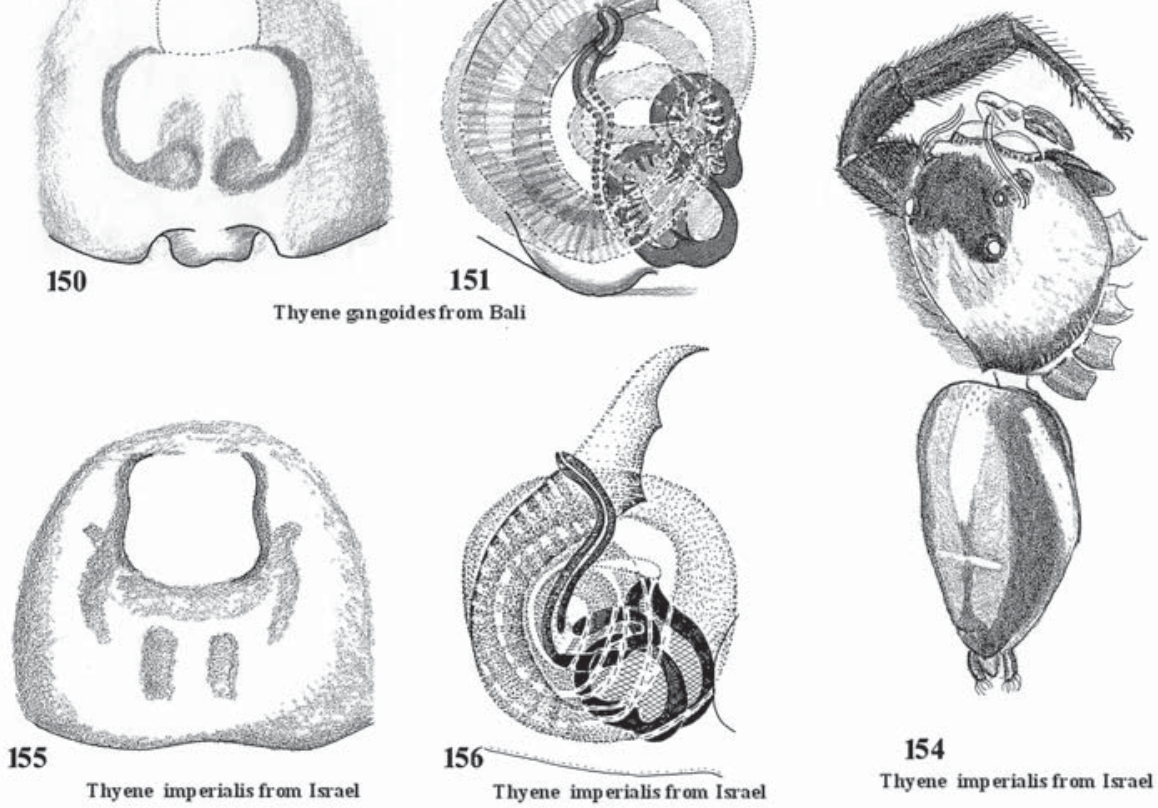

Figs 148-156. General appearance and epigyne of Thyene gangoides sp.n. (148-149, 150-151), T. benjamini sp.n. (152-153) and T. imperialis (154-156): 148-153, 154 - general appearance, dorsal and lateral views; 151-152, 155-156 - epigyne and its internal structures. 148-151 — from Bali; 152-153 — from Sumbawa; 154-156 — from Israel. 154-156 — after Prószyński [2003].

Рис. 148-156. Общий вид и эпигина Thyene gangoides sp.n. (148-149, 150-151), T. benjamini sp.n. (152-153) и T. imperialis (154-156): 148-153, 154 - общий вид, сверху и сбоку; 151-152, 155-156 - эпигина и внутренние структуры. 148-151 - с о. Бали; 152-153 — с о. Сумбава; 154-156 — из Израиля. 154-156 — по Prószyński [2003].

Thiania oppressa Simon, 1901: 588.

Euophrys chiariatapuensis Tikader, 1977: 206, f. 26A-B ( $\Im^{7}+$ ). Syn.n.

Thiania bhamoensis: Prószyński, 1983: 284, f. 5-6 (ơ)

Thiania bhamoensis: Prószyński, 1984b: $144\left(\bigcirc^{\top}\right)$ ).

Thiania bhamoensis: Żabka, 1985: 452, f. 616-624 (○’o).

Thiania bhamoensis: Peng, Xie, Xiao, Yin, 1993: 238, f. 848 854( ( $\left.{ }^{\top}+\right)$.

MATERIAL. $\sigma^{\top}$, Bali: Ambengan, secondary forest, 1. litter, 19-31.01.1990. Leg. Suh Djojosudharmo. CDML.
ETYMOLOGY. Named after the collection locality Bhamo, in Burma (= Myanmar).

REMARK. This species is widely distributed in SE Asia, apparently congeneric with the type species Thiania pulcherrima C.L. Koch, 1846 from Sulawesi [Merian, 1911: 310, f. VI]. It has a body shape characteristic of that genus (Fig. 142), and a pattern of iridescent scales, usually blue or violet, clearly visible in color 

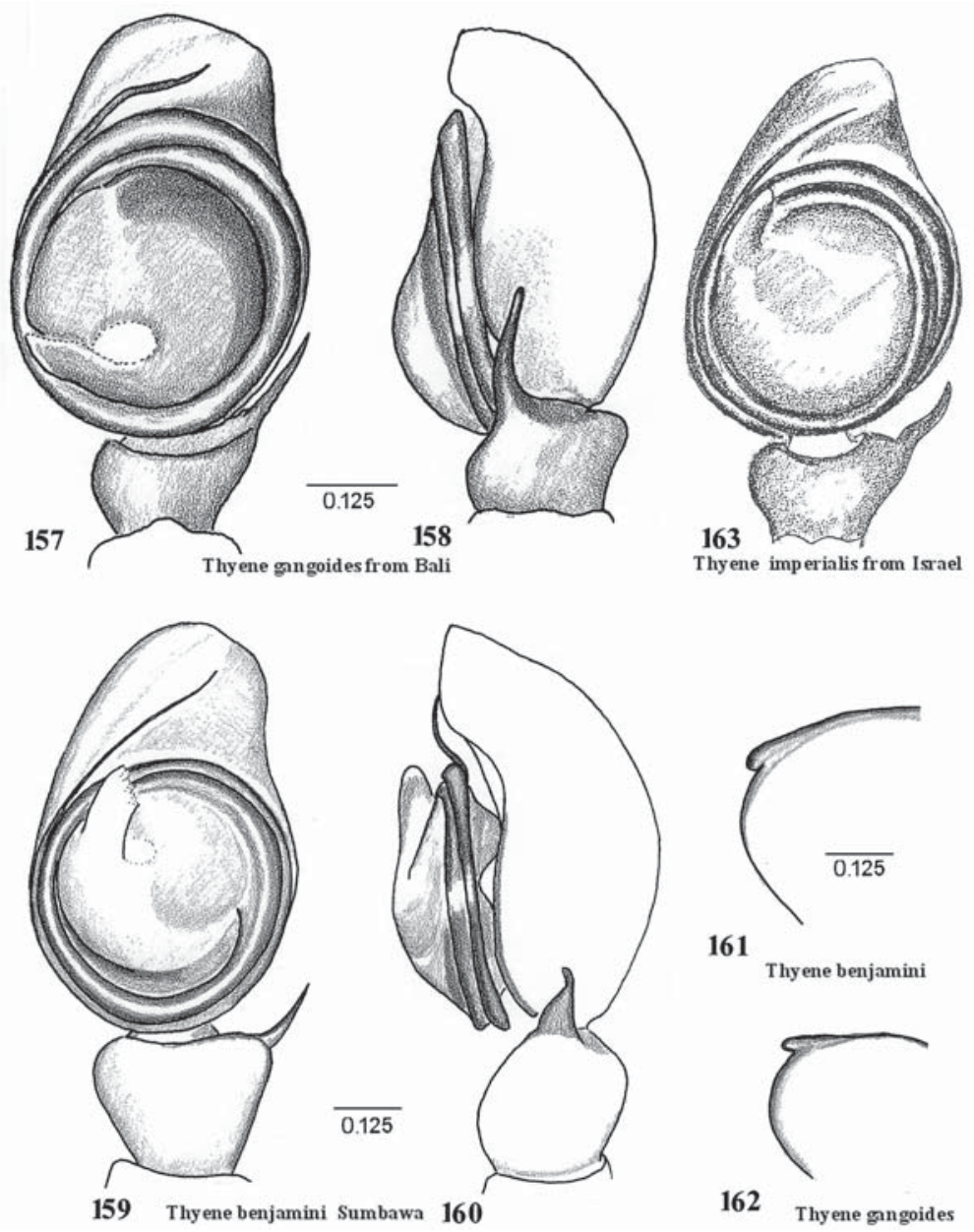

Figs 157-163. Palps and maxillary endites of Thyene gangoides sp.n. $(157-158,162)$, T. benjamini sp.n. (159-161), and T. imperialis (163): 157-160, 163 - palps, ventral and lateral views; 161-162 - maxillary endites. 157-158, 162 - from Bali; $159-161$ - from Sumbawa; 163 - from Israel. 163 — after Prószyński [2003].

Рис. 157-163. Пальпа и максиллы Thyene gangoides sp.n. (157-158, 162), T. benjamini sp.n. (159-161) и T. imperialis (163): 157160, 163 - пальпы, снизу и сбоку; 161-162 - максиллы. 157-158, 162 - с о. Бали; 159-161 - с о. Сумбава; 163 - из Израиля. 163 - по Prószyński [2003].

photographs [Prószyński, 2010 online]. That color pattern is not shown in Fig. 142, apparently due to the deterioration of the specimen at hand. The structure of the palpus (Figs 143-144) matches drawings in the literature. Epigyne (Fig. 145) conforms to that of the type specimen of $T$. bhamoensis from Burma, the drawing of the internal structures of the epigyne (Fig. 146) shows some fine details of the copulatory openings, scent gland and fertilization duct, that were insufficiently presented in a previously published drawing of the type specimen (Fig. 147, from Prószyński [1984b]).

Gen. Thyene Simon, 1885

The type species is T. imperialis (Rossi, 1846) from the Mediterranean.

REMARK. The genus Thyene Simon, 1885, as defined by its type species, is characterized by unique internal structures of the epigyne, consisting of a twochambered spermatheca on each side of the epigyne, surrounded by two circular coils of membranous copulatory ducts, which open through longitudinal slits at a membranous window in front of each spermatheca (Figs 150-151, 155-156). The armature of the scent gland opening has the form of a long, thin, longitudinal duct, parallel to the spermathecae and reaching far ahead of them. Externally the epigyne appears weakly sclerotized, has a single, anterior, white membranous window, and a pair (sometimes more) of translucent dark spots. The relationship of these spots to the internal structures has not been established. That structure of epigyne was found in all species, in which the epigyne was dissected and cleared. Its diagnostic importance outweighs any differences in other characters, including body shape. The palpus is also characteristic, and consists of a round bulbus surrounded by coils (usually 
two) of a thin embolus, with a soft flap in various positions. The tibial apophysis is simple, of medium length, and thin or slightly broader in its basal half (Figs 157-158, 159-160, 163). The structure and proportions of the palpus are comparable to those of some other genera, so may not be of the same diagnostic value for the genus as the epigyne is.

The diagnostic definition of the genus was a problem for several authors, beginning from Simon [1903] because of the unusual diversity in the shape of the carapace, which may be laterally expanded and high (Figs 152-153) or narrow and flat (Figs 148-149). There are also some differences in color pattern, which are presumably of specific value.

The diversity in the carapace shape is bewildering indeed [Prószyński, 1987, 2010 online]. In T. imperialis and several closely related species, the carapace is high and broad - expanded in the lower region, rounded or diamond like, with the eyefield located atop of the coneshaped part of carapace, which is the only flat area (Figs $152-153,154)$. At the other end of the spectrum is a carapace that is slim, low and flat for most of its length (Figs 148-149). These differences formed the basis for the descriptions of the genera Mithion Simon, 1884 and Gangus Simon, 1902. Currently, not less than 8 species with a relatively narrow carapace are included by various authors in Thyene (diagnostic drawings documented in Prószyński [2010 online]).

The synonymy of Mithion was subject of ICZN Opinion 1625 [1991: 69-70], which accepted Prószyński's [1984b] documentation and decided on precedence of the junior synonym Thyene over Mithion (except for 2 species of dubious status).

The type species of the poorly known genus Gangus Simon, 1902, viz Gangus concinnus (Keyserling, 1881) has an epigyne and a palpus typical for Thyene, as demonstrated by Davies \& Żabka [1989: 250, pl. 53]. The generic name Gangus was used in combination with five specific names, of which only two of these species have documented diagnostic drawings available. The similarity of Gangus longulus Simon, 1902, with Mithion semiargenteus Simon, 1884 (now Thyene semiargentea) was already noted by Simon [1903: 690 - footnote), who considered it as "assez frappant". Thus, we can accept that relationship on his authority, and by analogy, the relationship of Gangus decorus Simon, 1902. The transfer to Thyene of the species described in the genus Gangus was already proposed by Prószyński in 2003 (see the current version of Prószyński, 2010 online). Given that this proposal was not accepted by Platnick [2010], it is repeated here, with the following list of synonymies.

\section{Thyene concinna (Keyserling, 1881) comb.n.} $\left(\mathrm{O}^{\mathrm{T}}+\mathrm{A}\right)$.

Acompse concinnus Keyserling, 1881: 1322, pl. 112, f. 6-7

Gangus concinnus: Simon, 1903a: 706.

Gangus concinnus: Davies \& Żabka 1989: 250, pl. 53 ( $\left.{ }^{7}+\right)$.

Gangus concinnus: Platnick, 2009: online.

Thyene concinna: Prószyński, 2010 online $\left(\sigma^{7}+\right)$.
REMARK. This Australian species was defined by excellent drawings in Davies \& Żabka [1989], with narrow carapace, and internal structure of epigyne and palpus typical for Thyene. Type species of the genus Gangus Simon, 1902.

DISTRIBUTION. Australia: Queensland.

Thyene decora (Simon, 1902) comb.n.

Gangus decorus Simon, 1902: 390 (ㅇ)

Gangus decorus: Simon, 1903: 700, f. 823. da).

Gangus decorus: Prószyński, 2010 online (species inquiren-

Gangus decorus: Platnick, 2009: online.

REMARK. Species inquirenda pending revision of the type specimens kept in MNHN, transfer to the Thyene is based on comments by Simon [1903], supported by his drawing.

DISTRIBUTION. Australia.

\section{Thyene longula (Simon, 1902) comb.n.}

Gangus longulus Simon, 1902: 390 ( ( ${ }^{\top}$ ㅇ)

Gangus longulus : Simon, 1903 : 690 (footnote). da).

Gangus longulus: Prószyński, 2010 online (species inquiren-

Gangus longulus: Platnick, 2009: online.

REMARK. Species inquirenda, pending revision of the type kept in MNHN, transfer to Thyene is based on the remark of Simon [1903] on the intriguing similarity of this species to Mithion semiargenteus Simon, 1884 [= Thyene semiargentea $]$.

DISTRIBUTION. Australia.

Thyene manipisa (Barrion \& Litsinger, 1995) comb.n. $\left(0^{7}\right)$.

Gangus manipissus Barrion \& Litsinger, 1995: 64, f. 28a-g

T. manipissa: Prószyński, 2010 online $\left(\bigcirc^{7}\right)$.

Gangus manipissus: Platnick, 2010: online.

REMARK. A species with a narrow carapace and a palpus typical for Thyene. The transfer to Thyene is well supported by drawings in the original description by Barrion \& Litsinger, [1995].

DISTRIBUTION. The Philippines: Mindanao Island.

Thyene gangoides sp.n.

Figs 148-151, 157-158.

MATERIAL. + holotype, $\sigma^{7}$ allotype, Bali: Gilimanuk, 26.05.1959. Leg. Pisarski, Prószyński”. MiIZ.

ETYMOLOGY. Name relates to the synonymized generic name Gangus Simon, 1902.

DIAGNOSIS. Carapace and abdomen narrow, but with typical Thyene genital organs. Males differ from Thyene concinna (Keyserling, 1881) (see Davies \& Żabka [1989]) from Australia by the transverse direction of the flap on the proximal edge of the bulbous, and by the shape of the tibial apophysis, females differ in proportions and shape of the two spermathecal chambers. 

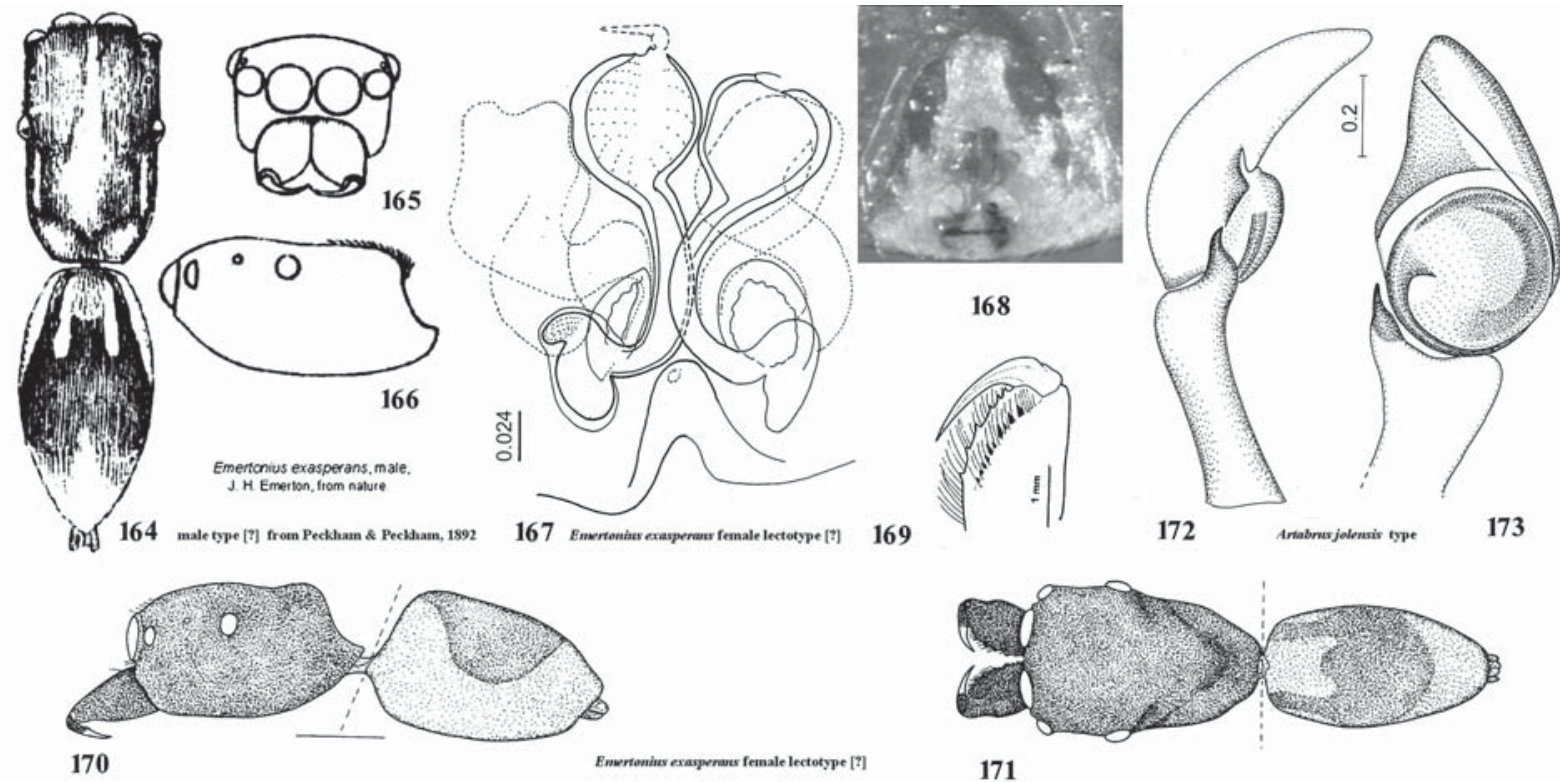

Figs 164-173. General appearance and copulatory organs of Emertonius exasperans (164-167, 169-171), unknown Myrmarachne sp. (168) and Telamonia jolensis (172-173): 164, 170-171 - general appearance, dorsal and lateral views; 165-166 - carapace, face and cheliceral dentition; 167 - internal structure of epigyne, in lectotype; 168 - epigyne of unknown Myrmarachne sp., barbarously substituted for lost epigyne; 172-173 — palpus, ventral and lateral view. 164-166 — after Peckham \& Peckham [1892]; 168 — photo by G.B. Edwards; 172-173 — after Prószyński [1987].

Рис. 164-173. Общий вид и копулятивные органы Emertonius exasperans (164-167, 169-171), неизвестный вид Myrmarachne (168) и Telamonia jolensis (172-173): 164, 170-171 - общий вид, сверху и сбоку; 165-166 - карапакс, «лицо» и вооружение хелицер; 167 - вульва, лектотип; 168 - эпигина неизвестного вида Myrmarachne; 172-173 — пальпа, снизу и сбоку. 164-166 по Peckham \& Peckham [1892]; 168 — фото G.B. Edwards; 172-173 — по Prószyński [1987].

DESCRIPTION. Male. Carapace slim and low, 3/ 4th of surface flat (Figs 148-149). Palpus with round bulbus, differing from $T$. concinna by the shape of the bulbus flap, located transversally at the posterior end of the bulbus, almost straight, not bent anteriorwards. The tibial apophysis is narrow, its length is about $1 / 3 \mathrm{rd}$ of the length of the cymbium (Figs 157-158). The bulbus flap and tibial apophysis are analogous to Thyene phragmitigrada Metzner, [1999] from Greece, but there are no such similarities in the dorsal pattern, nor in the female genital organs. There is a minute flap at the external angle of the maxillary endite (Fig. 162). Length of carapace 2.37, proportions LE 0.40 , HC 0.42, WE1 0.48, WE3 0.53, WC3 0.74, MWC 0.74, LDC 0.74, LA 1.37, MWA 0.61, leg I (as ratios to LC) 2.21. Length of legs ( 5 distal segments, in $\mathrm{mm}$ and as ratios to length of leg I): leg I $5.23=1.00$, leg II $3.18=0.61$, leg III $4.05=0.77$, leg IV $4.06=0.78$. Length of legs order I, IV, III, II.

Female. The membranous window in the epigyne is narrower than in $T$. concinnus. Its anterior part ovoid (rectangular in T. imperialis [compare Figs 150, 156]). Duct of the scent gland about as long as spermathecae, distinctly shorter than in T. imperialis (Figs 151, 153). Length of carapace 2.44, proportions LE 0.41 , HC 0.38, WE1 0.49, WE3 0.54, WC3 0.72, MW 0.72, LDC 0.72 , LA 0.143 , MWA 0.61 , leg I (as ratio of LC) 1.76. Length of legs ( 5 distal segments, in $\mathrm{mm}$ and as ratio to length of leg I): $\operatorname{leg}$ I $4.30=1.00$, leg II $3.18=0.74$, leg III $3.86=0.90$, leg IV $3.99=0.93$. Length of legs order: I, IV, III, II.

REMARK. One of several slim-bodied species of Thyene, light colored, with a dark mark on the posterior tip of the abdomen. See remark under Thyene (above).

DISTRIBUTION. Documented from Indonesia: Bali Island.

\section{Thyene benjamini sp.n.}

Figs 152-153, 159-160.

MATERIAL. $0^{7}$ holotype, Sumbawa: Samokat. CDML.

ETYMOLOGY. Named after the arachnologist Suresh P. Benjamin.

DIAGNOSIS. Resembles the type species of the genus - T. imperialis in body shape (Figs 152-153) and genital organs (Figs 159-160). The latter resemble also the genital organs of $T$. gangoides sp.n.(see above). It differs by its color pattern (compare Figs 152 and 154) and details of the palpus (Figs 159-160 and 163).

DESCRIPTION. Male. Lateral expansion of lower region of carapace angular, broadest at $1 / 3^{\text {rd }}$ of its length, as prominent as in the African species T. bucculenta (Gerstacker, 1873), from which it differs distinctly by its abdominal pattern. The length of the tibial apophysis is about $1 / 5^{\text {th }}$ the length of the cymbium. In lateral view the apophysis is conical with a small, bent tip (Figs 159-160). The minute flap at the external 
angle of the maxillary endite is somewhat larger than in T. gangoides (compare Figs 161 and 162).

Length of carapace 2.69, proportions LE 0.42 , HC 0.57, WE1 0.56, WE3 0.65, WC3 1.02, MWC 1.02, LA 111, MWA 0.69, leg I (as ratio to LC) 292. Length of legs ( 5 distal segments, in $\mathrm{mm}$ and as ratio to length of leg I): leg I $7.87=1.00$, leg II $5.18=0.66$, leg III $6.51=0.83$, leg IV $6.00=0.76$. Length of legs order I, III, IV, II.

Female unknown.

REMARK. One of a number of species of which the carapace is high and prominently expanded laterally (see remark under Thyene, above), with a dark reddish abdominal pattern, adorned with light transverse lines in the posterior half of the abdomen, and with a median longitudinal light streak anteriorly.

DISTRIBUTION. Documented from Indonesia: Sumbawa Island.

\section{Discussion}

We refrain from presenting a biogeographical interpretation of the Salticidae of the Lesser Sunda Islands, pending the publication of a study of the salticids of the Greater Sunda Islands (now in preparation), when the transitional nature of that faua will become more apparent.

The fauna of the Malay Archipelago is apparently very poorly known, with many more species yet to be discovered. The majority of existing descriptions and reports are inadequate, either because of the lack of diagniostic drawings of genital organs, or as a result of other faults. An unused source of important taxonomic data are color photographs of specimens kept by various photographers, but these lack documentation of the genital organs.

ACKNOWLEDGMENTS. We are grateful to the late Suharto Djojosudharmo who collected spiders in many parts of Indonesia, during the years 1983-2000, kept now in this collection, including those mentioned in this paper.

Permissions to reproduce a few comparative drawings from his papers were received from Dr. M. Żabka. Of great help were photographs by Mrss D. Knowles and P. Koomen. Very considerable editorial help was received from Dr Y. Marusik. Coquille paper for drawings was donated by Dr. W.P. Berry. The translation into English language was corrected by Dr. David Penney. Writing of this paper was assisted by the Museum and Institute of Zoology, Polish Academy of Sciences in Warsaw and by special grant N303341235 from the Ministry of Higher Education and Sciences of Poland.

The authors express their sincere and warm thanks to above mentioned persons and institutions.

\section{References}

Andreeva E.M., Kononenko A.P., Prószyński J. 1981. Remarks on genus Mogrus Simon, 1882 (Aranei, Salticidae) // Annales zoologici, Warszawa. T.36. P.85-104.
Audouin V. 1826. Explication sommaire des planches d'arachnides de l'Egypte et de la Syrie publiées in «Description de l'Egypte..». Histoire Naturelle, Paris. Vol.1. No.4. P.99-186.

Badcock H.D. 1918. Antlike spiders from Malaya, collected by the Annandale-Robinson Expedition 1901-02 // Proceedings of the zoological Society of London. Vol.1917. P.277-321.

Barrion A.T., Litsinger J.A. 1995. Riceland Spiders of South and Southeast Asia. CAB International + International Rice Research Institute. Wallingford, UK. 700 pp.

Benjamin S.P.2004. Taxonomic revision and phylogenetic hypothesis for the jumping spider subfamily Ballinae // Zoological Journal of the Linnean Society. London. Vol.142. P.1-82.

Berry J.W., Beatty J.A., Prószyński J. 1996. Salticidae of the Pacific Islands. I. Distribution of twelve Genera, with description of eighteen new species // Journal of Arachnology. Vol.24. No.3. P.214-253

Berry J.W., Beatty J.A., Prószyński J. 1997. Salticidae of the Pacific Islands. II. Distribution of nine genera, with description of eleven new species // Journal of Arachnology. Vol.25. No.2. P.109-136.

Berry J.W., Beatty J.A., Prószyński J. 1998. Salticidae of the Pacific Islands. III. Distribution of seven genera, with description of nineteen new species and two new genera // Journal of Arachnology. Vol.26. No.2. P.149-189.

Bonnet P.1955-1961. Bibliographia Araneorum. Analyse methodique de toute la litterature araneologique. Toulouse: Les Frères Douladoure. Vol.2. P.1-918.

Caporiacco L. 1947. Arachnida Africae Orientalis a dominibus Kittenberger, Kovacs et Bornemisza lecta // Annales historiconaturales Musei nationalis hungarici. Budapest. Vol.40. P.97257.

Clerck C. 1757. Aranei Suecici, descriptionibus et figuris oeneis illustrati, ad genera subalterna redacti speciebus ultra LX determinati. Svenska Spindlar, uti sina hufvudslagter indelte samt. $154 \mathrm{p}$.

Cho J.H., Kim J.P.2002. A revisional study of family Salticidae Blackwall, 1841 (Arachnida, Araneae) from Korea // Korean Arachnology. Vol.18. P.85-169.

Davies Todd V., Żabka M. 1989. Illustrated keys to the genera of jumping spiders (Araneae: Salticidae) in Australia // Memoirs of the Queensland Museum. Vol.27. No.2. P.189-266.

Davis S., Sudhikumar A.V., Jose K.S., Sebastian P.A. 2005. New record of the salticid spider Thiania bhamoensis Thorell (Araneae: Salticidae) from Kerala, India with its redescription and field notes on behavior // J. Bombay nat. Hist. Soc. Vol.102. P.245-249.

Doleschall C.L. 1859. Tweede Bijdrage tot de Kennis der Arachniden van den Indischen Arachipel // Acta Societatis scientiarum Indo-Neerlandicae. Vol.5. P.1-60.

Dyal S. 1935. Fauna of Lahore. 4. Spiders of Lahore // Bulletin of the Department of Zoology, Panjab University, Lahore 1. P.117252.

Edmunds M., Prószyński J. 2003. On a collection of Myrmarachne spiders (Araneae: Salticidae) from peninsula Malaya // Bulletin of the British arachnological Society. Vol.12. Pt.7. P.297-322.

Edwards G.B., Benjamin S.P. 2009. A first look at the phylogeny of the Myrmarachninae, with rediscovery and redescription of the type species of Myrmarachne (Araneae: Salticidae) // Zootaxa. No.2309. P.1-29.

Gerstacker A. 1873. Arachnoidea // von der Decken C. (ed.). Reisen in Ostafrica. Vol.3. No.2. P.461-503.

Huang J N. 2004. Taxonomic study of Myrmarachne (Araneae: Salticidae) from Taiwan. MSc Thesis, National Sun Yat-sen University, online. Kaohsiung. 87 p.

ICZN, 1991. Opinion 1625. Thyene Simon, 1885 (Arachnida, Araneae): given precedence over Mithion Simon, 1884 // Bulletin of zoological Nomenclature, London. Vol.48. No.1. P.69-70.

Karsch F. 1878. Exotisch-Araneologisches // Zeitschrift für die gesammten Naturwissenschaften. Bd.51. S.323-333, 771-826.

Karsch F. 1879. Arachnologische Beiträge // Zeitschrift für die gesammten Naturwissenschaften. Bd.52. S.534-562.

Karsch F. 1880. Arachnologische Blätter (Decas I) // Zeitschrift für die gesammten Naturwissenschaften. Bd.53. S.373-409. 
Karsch F. 1881. Diagnoses Arachnoidarum Japoniae // Berliner entomologische Zeitschrift, Bd.25. S.35-40.

Koch C.L. 1846. Die Arachniden. Nürnberg. Bd.13. S.1-234.

Keyserling E. 1881. Die Arachniden Australiens. Nürnberg. Bd.1. S. $1272-1324$.

Keyserling E. 1882. Die Arachniden Australiens, nach der Natur beschriebene und abgebildet. S.1325-1420.

Keyserling E. 1883. Die Arachniden Australiens, nach der Natur beschriebene und abgebildet. Nürnberg. S.1421-1489.

Koh J. 1989. A guide to common Singapore spiders. Singapore Science Centre. $160 \mathrm{p}$.

Kulczyński W. 1910. Araneae et Arachnoidea Arthrogastra // Botanische und zoologische Ergebnisse einer wissenschaftlichen Forschungsreise nach den Samoainseln, dem Neuguinea-Archipel und den Solomon inseln von Marz bis Dezember 1905 von Dr Karl Rechinger. III Teil 4. / Denkschriften der kaiserlichen Akademie der Wissenschaften zu Wien. Bd.85. S.389411.

Logunov D.V., Ikeda H., Ono H. 1997. Jumping spiders of the Genera Harmochirus, Bianor and Stertinius (Araneae, Salticidae) from Japan // Bulletin of the National Science Museum Series A (Zoology). Tokyo. Vol.23. No.1. P.1-16.

Logunov D.V. 2001. Redefinition of the Genus Bianor Peckham et Peckham, 1885 and Harmochirus Simon, 1885, with establishment of a new genus Sibianor gen. n. (Aranei. P.Salticidae) // Arthropoda Selecta. Vol.9 (for 2000). No.4. P.221-286.

MacLeay W.S. 1839. On some new forms of Arachnida // Annals and Magazine of natural History. Vol.2. P.1-14.

Maddison W.P., Hedin M.C. 2003b. Jumping spiders phylogeny // Invertebrate Systematics. Vol.17. P.529-549.

Merian P.1911. Die Spinnenfauna von Celebes. Beiträge zur Tiergeographie im Indo-australischen Archipel // Zoologische Jahrbücher. II Abteilung für Systematik. Vol.31. P.165-354.

Metzner H. 1999. Die Springspinnen (Araneae, Salticidae) Griechenlands // Andrias. Vol.14. P.1-279.

Murphy F., Murphy J. 2000. An Introduction to the Spiders of South East Asia. Malaysian Nature Society. Singapore. 624 pp.

Peckham G.W., Peckham E.G. 1907. The Attidae of Borneo // Transactions of the Wisconsin Academy of Sciences, Arts and Letters. Vol.15. P.603-653.

Peng X.J., Tso I.M., Li S.Q., 2002. Five new and four newly recorded species of jumping spiders from Taiwan (Araneae: Salticidae) // Zoological studies, Taipei. Vol.41. P.1-12.

Peng X.J., Xie L.P., Xiao X.Q., Yin C.M. 1993. Salticids in China (Arachnida: Araneae). Hunan Normal University Press. 270 pp.

Pickard-Cambridge O. 1869. Descriptions and Sketches of some New Species of Araneida, with Characters of a New genus // Annals and Magazine of natural History. Vol.4. No.3. P.5274

Platnick N.I. 2010. The World Spider Catalog, Version 10.5. American Museum of Natural History, New York. Online at http:// research.amnh.org/iz/spiders/catalog/

Prószyński J. 1983. Redescriptions of types of Oriental and Australian Salticidae (Araneae) in Hungarian Natural History Museum in Budapest // Folia entomologica hungarica. Vol.44. No.2. P.283-297.

Prószyński J. 1984a. Remarks on Viciria and Telamonia (Araneae, Salticidae) // Annales zoologici, Warszawa. T1.37. No.18. P.418-436.

Prószyński J. 1984b. Atlas rysunkow diagnostycznych mniej znanych Salticidae. Siedlce: Zeszyty Naukowe WSRP. 177 pp.

Prószyński J. 1987. Atlas rysunkow diagnostycznych mniej znanych Salticidae 2. Siedlce: Zeszyty Naukowe WSRP. 172 pp.

Prószyński J. 1992. Salticidae (Araneae) of India in the collection of the Hungarian National Natural History Museum in Budapest // Annales zoologici. Warszawa. T.44. No.9. P.165-227.

Prószyński J. 1996. Salticidae (Araneae) distribution over Indonesian and Pacific Islands // Revue Suisse de Zoologie. Vol hors serie. P.531-536.

Prószyński J. 2003. Salticidae (Araneae) of the Levant // Annales zoologici. Warszawa. T.53. No.1. P.1-180.
Prószyński J. 2008. A survey of Havaika (Araneae. P.Salticidae), an endemic genus from Hawaii, including descriptions of new species // Arthropoda Selecta. Vol.16 (for 2007). No.4. P.195-213.

Prószyński J. 2009a. Obituary of E.M. Andreeva // Arthropoda Selecta. Vol.17 (for 2008). No.3-4. P.215-224.

Prószyński J. 2009b. Redescription of 16 species of Oriental Salticidae (Araneae) described by F. Karsch, E. Keyserling and C.L. Koch, with remarks on some related species // Arthropoda Selecta. Vol.18. No.3-4. P.153-168.

Prószyński J. 2010. Monograph of Salticidae (Araneae) of the World, Version 2010. http: //www.miiz.waw.pl/salticid/ main.htm

Reimoser E. 1925. Fauna sumatrensis (Beitrag Nr.7). Araneina // Supplementa entomologica, Berlin. Vol.10. P.89-94.

Roewer C.F. 1938. Araneae // Résultats scientifiques du Voyage aux indes orientales néerlandaises de la SS. AA. RR. le Prince et la Princesse Leopold de Belgique. Mémoires du Musée royal d'histoire naturelle de Belgique. (Hors Serie), Bruxelles. Vol.3. No.19. P.1-94.

Rossi F. 1846. Neue Arten von Arachniden des k. k. Museums, bechrieben und mit Bermerkungen über verwandte Formen belgleitet von... // Naturwissenschaftliche Abhandlungen. Wien. Vol.1. P.11-19.

Simon E. 1884. Arachnides recueillis a Khartoum (Soudan egyptien) par M. Vossion, vice-consul de France et appartenant au Museum de Paris // Bulletin de la Société zoologique de France. Vol.9. P.1-28

Simon E. 1885. Materiaux pour servir a la fauna arachnologique de l'Asie meridionale. III. Arachnides recueillis en 1884 dans la presqu'ile de Malacca, par M. J. Morgan. IV. Arachnides recueillis a Collegal, district de Coimbatoore, par M. A. Theobald G. R. // Bulletin de la Société zoologique de France. Vol.10. P.436-455, 456-462.

Simon E. 1889. Etudes arachnologiques. 21e Memoire. XXXIII Descriptions de quelques especes recueillies au Japan, par A. Mellotee // Annales de la Société entomologique de France. Vol.6. No.8. P.248-252.

Simon E. 1900. Etudes arachnologiques. 30e Memoire. XLVII. Description d'especes nouvelles de la famille des Attidae // Annales de la Société entomologique de France. T.69. P.2761

Simon E. 1901. Histoire Naturelle des Araignées. Paris. Vol.2. No.3. P.381-668

Simon E. 1902. Etudes arachnologiques. 32e. Memoire. LI. Descriptions d'especes nouvelles de la famille des Salticidae (suite) // Annales de la Société entomologique de France. Vol.71. P.389-421.

Simon E. 1903. Histoire Naturelle des Araignées. Paris. Vol.2. No.3-4. 669-1080

Thorell T. 1877. Studi sui Ragni Malesi e Papuani. I. Ragni di Selebes raccolti nel 1874 dal Dott. O. Beccari // Annali del Museo civico di Storia naturale. Genova. Vol.10. P.341-634.

Thorell T. 1878. Studi sui Ragni Malesi e Papuani. Part II. Ragni di Amboina raccolti dal Prof. O. Beccari // Annali del Museo civico di Storia naturale, Genova. Vol.13. P.1-317.

Thorell T. 1881. Studi sui Ragni Malesi e Papuani. III. Ragni dell'Austro Malesia e del Capo York, conservati nel Muso civico di storia naturale di Genova // Annali del Museo civico di Storia naturale. Genova. Vol.17. P 1-720.

Thorell T. 1887. Viaggio di L. Fea in Birmania e regioni vicine. II. Primo saggio sui ragni birmani // Annali del Museo civico di Storia naturale di Genova. Genova. Vol.25. P.5-417.

Thorell T. 1890. Diagnoses aranearum aliquot novarum in IndoMalesia inventarum // Annali del Museo civico di Storia naturale. Genova. Vol.30. P.132-172.

Thorell T. 1892. Studi sui Ragni Malesi e Papuani. IV, 2 // Annali del Museo civico di Storia naturale di Genova. Genova. Vol.31. P.1-490.

Thorell T. 1895. Descriptive Catalogue of the Spiders of Burma. $406 \mathrm{p}$.

Tikader B.K. 1977. Studies on spider fauna of Andaman and Nicobar islands, Indian Ocean // Records of the zoological Survey of India. Vol.72. P.153-212. 
Wallace A.R. 1881. Island life, or, The phenomena and causes of insular faunas and floras, including a revision and attempted solution of the problem of geological climates. 522 p.

Wanless F.R. 1978a. A revision of the spider genera Belippo and Myrmarachne (Araneae, Salticidae) in the Ethiopian region // Bulletin of the British Museum (Natural History) (Zoology series). Vol.33. No.1. P.1-139.

Wanless F.R. 1978b. On the identity of the spider Emertonius exasperans Peckham and Peckham (Araneae, Salticidae) // Bulletin of the British Museum (Natural History) (Zoology series). Vol.33. No.4. P.235-238.

Wanless F.R. 1981. A revision of the spider genus Phaeacius (Araneae, Salticidae) // Bulletin of the British Museum (Natural History) (Zoology series). Vol.41. No.4. P.199-219.

Wanless F.R. 1984. A review of the spider subfamily Spartaeinae nom. n. (Araneae. P.Salticidae) with descriptionof six new genera. // Bulletin of the British Museum (Natural History) (Zoology series). Vol.46. No.2. P.135-198.

Wijesinghe D.P.1991. New species of Phaeacius from Sri Lanka, Sumatra and Philippines (Araneae. P.Salticidae) // Bulletin of the British arachnological Society. Vol.8. Pt.8. P.249-255.
Zabka M. 1985. Systematic and zoogeographic study on the family Salticidae (Araneae) from Viet-Nam // Annales zoologici. Warszawa. T.39. No.11. P.197-485.

Zabka M. 1988. Salticidae (Araneae) of Oriental, Australian and Pacific Regions III // Annales zoologici, Warszawa. T.41. No.14. P.421-479.

Żabka M. 1991. Studium taksonomiczno-zoogeograficzne nad Salticidae (Arachnida. P.Araneae) Australii // Rozprawa Naukowa Wyższej Szkoły Rolniczo Pedagogicznej, Siedlce. Vol.32. P.1110.

Żabka M. 2002. Salticidae (Arachnida. P.Araneae) from Oriental, Australian and Pacific Regions, XV. New species of Astiae // Records of the Australian Museum. Vol.54. P.257-268.

Żabka M. 2009. Salticidae (Arachnida. P.Araneae) from Oriental, Australian and Pacific Regions. P.Astilodes and Urogelides, new genera from Australia // Insect Systematics \& Evolution. Vol.40. P.349-359.

Zhang J.X., Song D.X., Li D.Q. 2003. Six new and one newly recorded species of Salticidae (Arachnida, Araneae) from Singapore and Malaysia // Raffles Bulletin of Zoology. Vol.51. No.2. P.187-195. 